\title{
ÆUSGS
}

science for a changing world

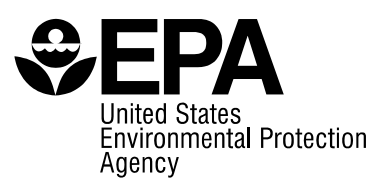

Prepared in cooperation with the U.S. Environmental Protection Agency and the Oregon Climate Change Research Institute

\section{Potential Climate-Induced Runoff Changes and Associated Uncertainty in Four Pacific Northwest Estuaries}

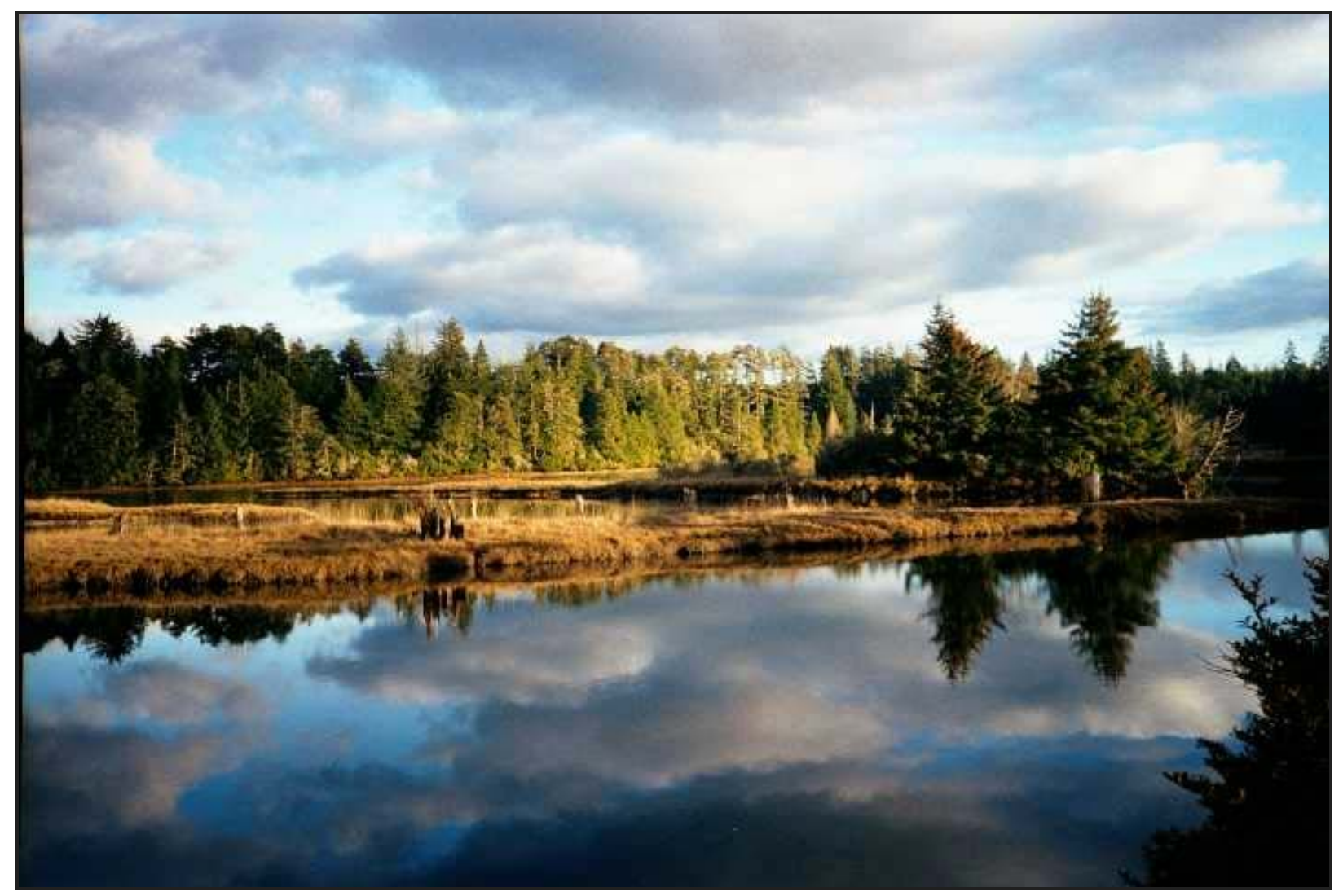

Open-File Report 2012-1274

U.S. Department of the Interior

U.S. Geological Survey 
Cover. National Estuarine Research Reserve in the South Slough of Coos Bay (Wikimedia Commons, 2010) 


\section{Potential Climate-Induced Runoff Changes and Associated Uncertainty in Four Pacific Northwest Estuaries}

By Madeline O. Steele ${ }^{1}$, Heejun Chang ${ }^{1}$, Deborah A. Reusser², Cheryl A. Brown³, and II-Won Jung ${ }^{1}$

1. Portland State University, Portland, OR. 2. U.S. Geological Survey, Western Fisheries Research Center, Newport Duty Station, Newport, OR. 3. U. S. EPA, Western Ecology Division, Newport, OR.

Prepared in cooperation with the U.S. Environmental Protection Agency and the Oregon Climate Change Research Institute

Open-File Report 2012-1274

U.S. Department of the Interior

U.S. Geological Survey 


\section{U.S. Department of the Interior \\ KEN SALAZAR, Secretary}

\section{U.S. Geological Survey \\ Marcia K. McNutt, Director}

U.S. Geological Survey, Reston, Virginia: 2012

For more information on the USGS-the Federal source for science about the Earth, its natural and living resources, natural hazards, and the environment-visit http://www.usgs.gov or call 1-888-ASK-USGS

For an overview of USGS information products, including maps, imagery, and publications, visit $h$ ttp://www.usgs.gov/pubprod

To order this and other USGS information products, visit http://store.usgs.gov

\footnotetext{
Suggested citation:

Steele, M.O., Chang, Heejun, Reusser, D.A., Brown, C.A., and Jung, I.-W., 2012,

Potential climate-induced runoff changes and associated uncertainty in four Pacific Northwest estuaries: U.S. Geological Survey Open-File Report 2012-1274, 63 p.
}

Any use of trade, product, or firm names is for descriptive purposes only and does not imply endorsement by the U.S. Government.

Although this report is in the public domain, permission must be secured from the individual copyright owners to reproduce any copyrighted material contained within this report. 


\section{Contents}

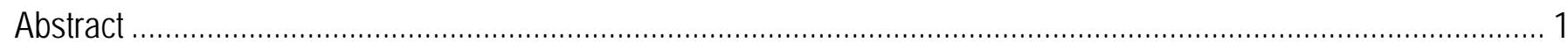

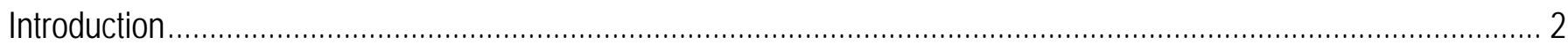

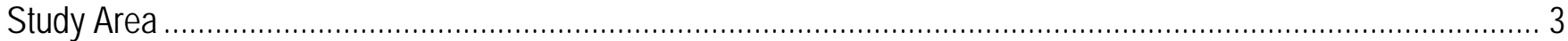

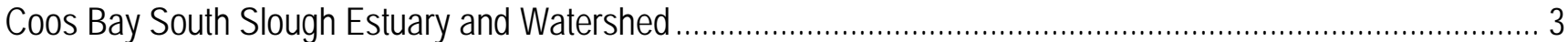

Coquille River Estuary and Watershed............................................................................................ 5

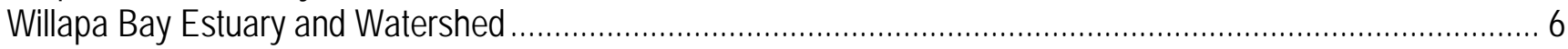

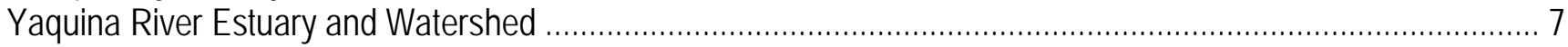

Data

Geographic Information System (GIS) Data........................................................................................

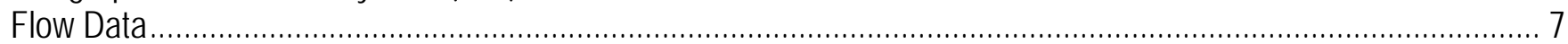

Historical Climate Data

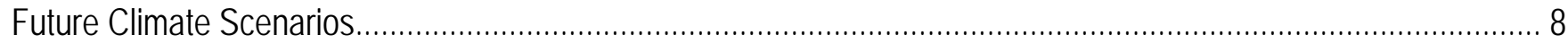

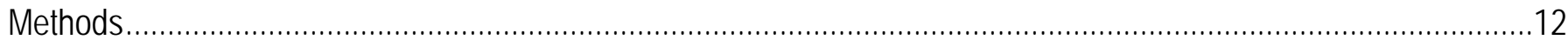

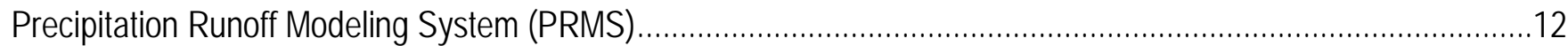

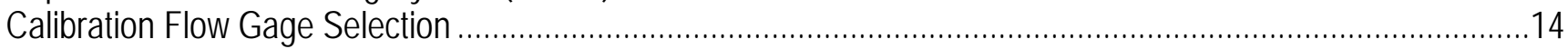

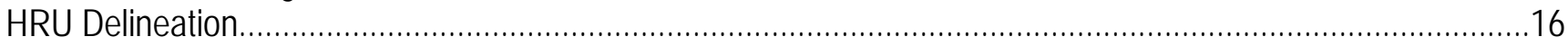

HRU Parameterization ……………………………

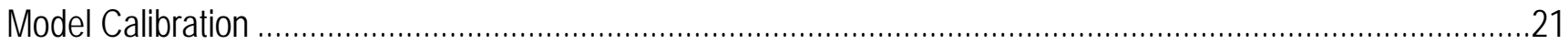

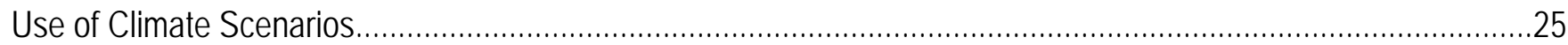

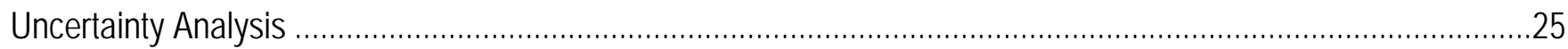

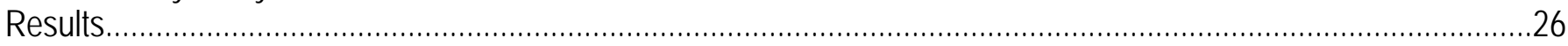

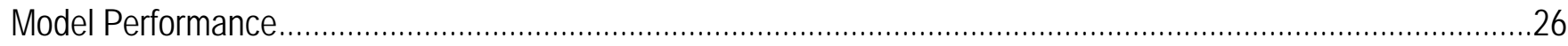

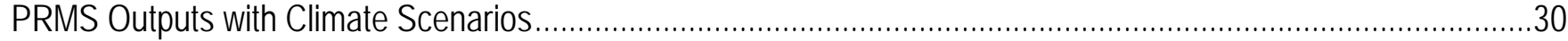

Percent Change in Monthly Mean Flow Rate from Reference Period to Future Period.........................................30

Changes in Monthly Coefficient of Variation (CV) from Reference to Future Period .........................................34

Changes in Other Indices from Reference Period to Future Period...............................................................34

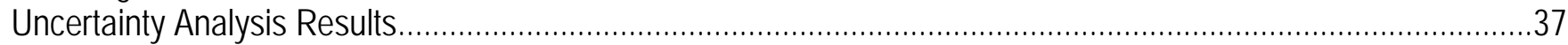

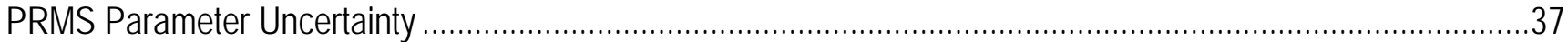

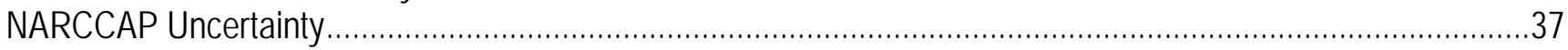

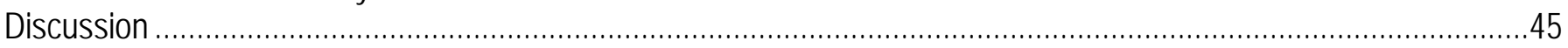

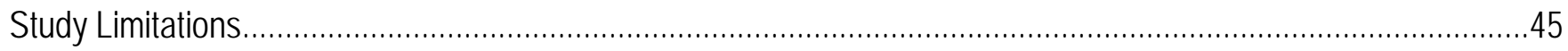

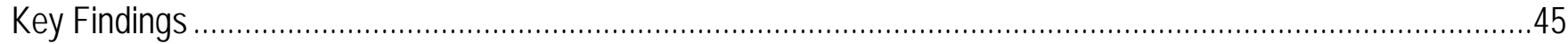

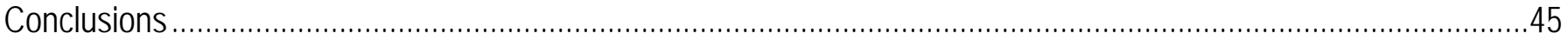

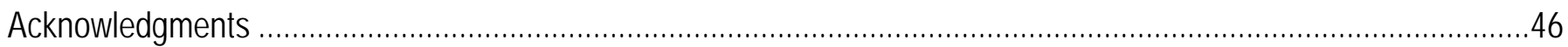

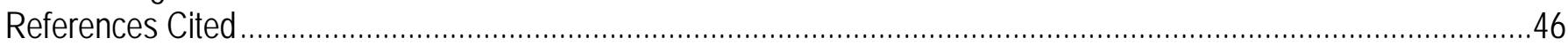

Appendix A. Presentations and Posters Based on this Research.....................................................................52 


\section{Figures}

Figure 1. Location of four study-area watersheds, Washington and Oregon.......................................

Figure 2. U.S. Geological Survey National Land Cover Dataset Land Use-Land Cover composition in each of the four study-area watersheds, Oregon and Washington, 2011.

Figure 3. Terrine or geologic group composition in each of the four study-area watersheds, based on Oregon

Geologic Data Compilation (Ma and others, 2009). 6

Figure 4. Examples of North American Regional Climate Change Assessment Program scenario outputs. 9

Figure 5. Absolute change in mean maximum daily temperatures from reference period (1971-95) to future period (2041-65) by month, in the Yaquina Bay watershed, Oregon.

Figure 6. Percent change in mean total daily precipitation from reference period (1971-95) to future period (2041-

65) by month, Yaquina Bay watershed, Oregon. 11

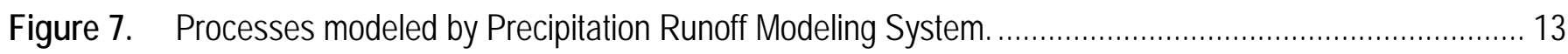

Figure 8. Calibration data for Coquille River watershed, Oregon .................................................................. 14

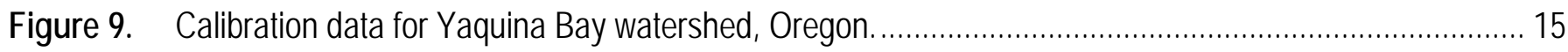

Figure 10. Calibration data for Willapa Bay watershed, Washington. …………………………..................... 15

Figure 11. Calibration data for Coos Bay South Slough watershed, Oregon. .................................................. 16

Figure 12. Hydrologic Response Units (HRUs) for Coos Bay South Slough watershed, Oregon. ........................ 17

Figure 13. Hydrologic Response Units (HRUs) for Coquille River watershed, Oregon....................................... 18

Figure 14. Hydrologic Response Units (HRUs) for Willapa Bay watershed, Washington. ................................... 19

Figure 15. Hydrologic Response Units (HRUs) for Yaquina Bay watershed, Oregon ........................................ 20

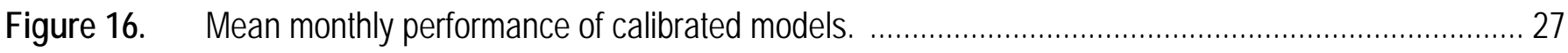

Figure 17. Monthly hydrograph of Coos Bay calibration sub-watershed, Oregon, Oct. 1982-Sept. 1991 _.......... 28

Figure 18. Monthly hydrograph of Coquille River calibration sub-watershed, Oregon, Oct. 1982-Sept. 1991_.... 28

Figure 19. Monthly hydrograph of Willapa Bay calibration sub-watershed, Washington, Oct. 1982- Sept. 1991. 29 
Figure 20. Monthly hydrograph of Yaquina Bay calibration sub-watershed, Oregon, Oct. 1982-Sept. 1991....... 29

Figure 21. Percent change in mean monthly percent flow from reference period (1971-1995) to future period (2041-2065), Coos Bay South Slough watershed, Oregon.

Figure 22. Percent change in mean monthly percent flow from reference period (1971-1995) to future period (2041-2065), Coquille River watershed, Oregon.

Figure 23. Percent change in mean monthly percent flow from reference period (1971-1995) to future period (2041-2065), Willapa Bay watershed, Washington.

Figure 24. Percent change in mean monthly percent flow from reference period (1971-1995) to future period (2041-2065), Yaquina Bay watershed, Oregon. 33

Figure 25. Percent change in mean monthly percent flow from reference period (1971-1995) to future period (2041-2065), averaged across all four study-area watersheds. 33

Figure 26. Climate scenario ensemble mean change in mean monthly percent flow from reference point (19711995) to future period (2041-2065), by study-area watershed. 34

Figure 27. Graph showing percent change in monthly coefficient of variation (CV) from reference period (19711995) to future period (2041-2065), averaged across all four study-area watersheds.

Figure 28. Graph showing climate scenario ensemble mean change in monthly coefficient of variation (CV) from reference period (1971-1995) to future period (2041-2065), by study-area watershed. 35

Figure 29. Graph showing percent change in flow in top 5 percent of days from reference period (1971-1995) to future period (2041-2065). 36

Figure 30. Graph showing percent change in 7-day low flow from reference period (1971-1995) to future period (2041-2065). 36

Figure 31. Precipitation Runoff Modeling System parameter uncertainty for Coos Bay calibration sub-watershed,

Oregon. (a) is a linear scale, and (b) is a logarithmic scale. 38 
Figure 32. Precipitation Runoff Modeling System parameter uncertainty for Coquille River calibration subwatershed, Oregon. (a) is a linear scale, and (b) is a logarithmic scale.

Figure 33. Precipitation Runoff Modeling System parameter uncertainty for Willapa Bay calibration sub-watershed, Washington. (a) is a linear scale, and (b) is a logarithmic scale. 40

Figure 34. Precipitation Runoff Modeling System parameter uncertainty for Yaquina Bay calibration subwatershed, Oregon. (a) is a linear scale, and (b) is a logarithmic scale. 41

Figure 35. Box-and-whisker plots showing changes in top 5 percent high flow, 7-day low flow, and coefficient of variation for four study areas. The lines in the middle of boxes denote the median values, and the upper and lower boundaries of the boxes show the 25th and 75th percentiles, respectively. The red diamond symbol indicates outliers. A is for RCM3-CGCM, $B$ is for HRM3-HADCM3, $\mathrm{C}$ is for CRCM-CGCM3, and $\mathrm{D}$ is for CRCM-CCSM. 42

Figure 36. Box-and-whisker plots showing changes in monthly runoff for four study areas. The lines in the middle of boxes denote the median values, and the upper and lower boundaries of the boxes show the 25 th and 75 th percentiles, respectively. The red diamond symbol indicates outliers. A is for RCM3-CGCM, B is for HRM3-HADCM3, $\mathrm{C}$ is for CRCM-CGCM3, and D is for CRCM-CCSM. 44 


\section{Tables}

Table 1. Watershed area, estuary type, elevation, and slope for the four study-area watersheds 6

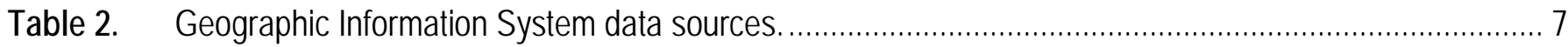

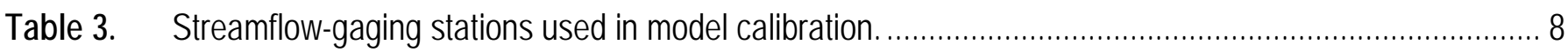

Table 4. North American Regional Climate Change Assessment Program climate scenarios used to force Precipitation Runoff Modeling System models......................................................................................... 10

Table 5. Number of Hydrologic Response Units (HRUs) in each watershed and calibration sub-watershed......... 20

Table 6. Hydrologic Response Unit parameters derived from Geographic Information System data. ................. 21

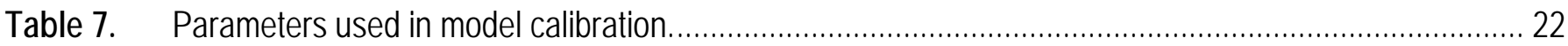

Table 8. Runoff ratios in all calibration sub-watersheds, and new runoff ratios in the Willapa calibration sub-

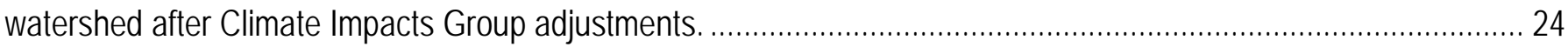

Table 9. Precipitation Runoff Modeling System parameters used in uncertainty analysis. ............................. 26

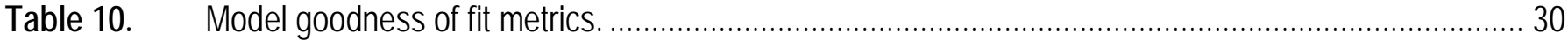




\section{Conversion Factors, Datums, Abbreviations and Acronyms}

\begin{tabular}{lll}
\multicolumn{1}{c}{ SI to Inch/Pound } & \multicolumn{1}{c}{ Bultiply } & \\
\hline & Length & \\
\hline millimeter $(\mathrm{mm})$ & 0.03937 & inch (in.) \\
meter $(\mathrm{m})$ & 3.281 & foot $(\mathrm{ft})$ \\
kilometer $(\mathrm{km})$ & 0.6214 & mile (mi) \\
meter $(\mathrm{m})$ & 1.094 & yard $(\mathrm{yd})$ \\
\hline & Area & \\
\hline square kilometer $\left(\mathrm{km}^{2}\right)$ & 247.1 & acre \\
square kilometer $\left(\mathrm{km}^{2}\right)$ & 0.3861 & square mile $\left(\mathrm{mi}{ }^{2}\right)$ \\
\hline & Volume & \\
\hline cubic meter $\left(\mathrm{m}^{3}\right)$ & 0.000811 & acre-foot (acre-ft) \\
\hline & Flow rate & \\
\hline cubic meter per second $\left(\mathrm{m}^{3} / \mathrm{s}\right)$ & 70.07 & acre-foot per day (acre-ft/d) \\
cubic meter per second $\left(\mathrm{m}^{3} / \mathrm{s}\right)$ & 35.31 & cubic foot per second (ft $\left.{ }^{3} / \mathrm{s}\right)$ \\
cubic meter per second $\left(\mathrm{m}^{3} / \mathrm{s}\right)$ & 22.83 & million gallons per day (Mgal $/ \mathrm{d})$ \\
\hline
\end{tabular}

Inch/Pound to SI

\begin{tabular}{rcl}
\hline Multiply & By & \multicolumn{1}{c}{ To obtain } \\
\hline & Volume & \\
\hline acre-foot (acre-ft) & $1,233.00$ & cubic meter $\left(\mathrm{m}^{3}\right)$ \\
acre-foot (acre-ft) & 0.00123 & cubic hectometer $\left(\mathrm{hm}^{3}\right)$ \\
\hline
\end{tabular}

Concentrations of chemical constituents in water are given either in milligrams per liter $(\mathrm{mg} / \mathrm{L})$ or micrograms per liter $(\mu \mathrm{g} / \mathrm{L})$.

\section{Datums}

Vertical coordinate information is referenced to the North American Vertical Datum of 1988 (NAVD 88).

Horizontal coordinate information is referenced North American Datum of 1983 (NAD 83).

Elevation, as used in this report, refers to distance above sea level based on NAVD 88. 


\section{Acronyms and Abbreviations}

\begin{tabular}{|c|c|}
\hline AOGCM & Atmosphere-Ocean General Circulation Model \\
\hline CCSM & Climate Change Simulation Model \\
\hline CIG & Climate Impacts Group \\
\hline COOP & Cooperative Observer Program \\
\hline CRCM-CCSM & Canadian Regional Climate Model-NCAR Community Climate Model version 3 \\
\hline CRCM-CGCM3 & Canadian Regional Climate Model-Canadian Global Climate Model version 3 \\
\hline CV & Coefficient of Variation \\
\hline DEM & Digital Elevation Model \\
\hline DO & Dissolved Oxygen \\
\hline DOGAMI & Oregon Department of Geology and Mineral Industries \\
\hline GCM & Global Climate Models \\
\hline GIS & Geographic Information System \\
\hline HRM3-HADCM3 & Hadley Regional Model version 3-Hadley Centre Climate Model version 3 \\
\hline HRU & Hydrologic Response Unit \\
\hline LULC & Land Use-Land Cover \\
\hline MATLAB & Matrix Laboratory \\
\hline NARCCAP & North American Regional Climate Change Assessment Program \\
\hline NLCD & National Land Cover Dataset \\
\hline NRCS & National Resources Conservation Service \\
\hline NSE & Nash Sutcliffe Efficiency \\
\hline OCCRI & Oregon Climate Change Research Institute \\
\hline OWRD & Oregon Water Resources Department \\
\hline PNW & Pacific Northwest \\
\hline PRECIP & Total Precipitation \\
\hline PRISM & Parameter-elevation Regressions on Independent Slopes Model \\
\hline PRMS & Precipitation Runoff Modeling System \\
\hline $\mathbf{R}^{2}$ & Coefficient of determination \\
\hline $\mathrm{RCM}$ & Regional Climate Model \\
\hline RCM3-CGCM & $\begin{array}{l}\text { Regional Climate Model-(National Center for Atmospheric Research) Canadian } \\
\text { Global Climate System Model version } 3\end{array}$ \\
\hline SSURGO & Soil Survey Geographic (SSURGO) Database \\
\hline TASMAX & Maximum daily surface air temperature \\
\hline TASMIN & Minimum daily surface air temperature \\
\hline TMAX & Maximum temperature \\
\hline TMIN & Minimum temperature \\
\hline USGS & U. S. Geological Survey \\
\hline
\end{tabular}




\title{
Potential Climate-Induced Runoff Changes and Associated Uncertainty in Four Pacific Northwest Estuaries
}

By Madeline O. Steele, Heejun Chang, Deborah A. Reusser, Cheryl A. Brown, and II-Won Jung

\begin{abstract}
As part of a larger investigation into potential effects of climate change on estuarine habitats in the Pacific Northwest, we estimated changes in freshwater inputs into four estuaries: Coquille River estuary, South Slough of Coos Bay, and Yaquina Bay in Oregon, and Willapa Bay in Washington. We used the U.S. Geological Survey’s Precipitation Runoff Modeling System (PRMS) to model watershed hydrological processes under current and future climatic conditions. This model allowed us to explore possible shifts in coastal hydrologic regimes at a range of spatial scales. All modeled watersheds are located in rainfall-dominated coastal areas with relatively insignificant base flow inputs, and their areas vary from 74.3 to 2,747.6 square kilometers. The watersheds also vary in mean elevation, ranging from 147 meters in the Willapa to 1,179 meters in the Coquille. The latitudes of watershed centroids range from 43.037 degrees north latitude in the Coquille River estuary to 46.629 degrees north latitude in Willapa Bay. We calibrated model parameters using historical climate grid data downscaled to onesixteenth of a degree by the Climate Impacts Group, and historical runoff from sub-watersheds or neighboring watersheds. Nash Sutcliffe efficiency values for daily flows in calibration sub-watersheds ranged from 0.71 to 0.89 . After calibration, we forced the PRMS models with four North American Regional Climate Change Assessment Program climate models: Canadian Regional Climate Model(National Center for Atmospheric Research) Community Climate System Model version 3, Canadian Regional Climate Model-Canadian Global Climate Model version 3, Hadley Regional Model version 3Hadley Centre Climate Model version 3, and Regional Climate Model-Canadian Global Climate Model version 3. These are global climate models (GCMs) downscaled with regional climate models that are embedded within the GCMs, and all use the A2 carbon emission scenario developed by the Intergovernmental Panel on Climate Change. With these climate-forcing outputs, we derived the mean change in flow from the period encompassing the 1980s (1971-1995) to the period encompassing the 2050s (2041-2065). Specifically, we calculated percent change in mean monthly flow rate, coefficient of variation, top 5 percent of flow, and 7-day low flow. The trends with the most agreement among climate models and among watersheds were increases in autumn mean monthly flows, especially in October and November, decreases in summer monthly mean flow, and increases in the top 5 percent of flow. We also estimated variance in PRMS outputs owing to parameter uncertainty and the selection of climate model using Latin hypercube sampling. This analysis showed that PRMS low-flow simulations are more uncertain than medium or high flow simulations, and that variation among climate models was a larger source of uncertainty than the hydrological model parameters. These results improve our understanding of how climate change may affect the saltwater-freshwater balance in Pacific Northwest estuaries, with implications for their sensitive ecosystems.
\end{abstract}




\section{Introduction}

Estuaries of the Pacific Northwest (PNW) provide critical habitat for fish, shellfish, and fowl that may be affected negatively as anthropogenic climate change leads to increasing air temperatures, sea level rise, shifts in the intensity and frequency of storms, changes in oceanic temperature and $\mathrm{pH}$, and changes in the timing and volume of freshwater inputs (Ruggiero and others, 2010). To better understand and help partners prepare for these potential changes, the U.S. Geological Survey (USGS), through the National Climate Change and Wildlife Science Center, lead a multi-agency and interdisciplinary investigation in collaboration with the U.S. Environmental Protection Agency (EPA) to model the range of ecological and physical effects of climate shifts in PNW estuaries. The primary objectives of the research project are to predict the effect of climate-related alterations on the distribution and abundance of two species of oysters, two species of seagrass, and tidal marsh habitat. In many PNW estuaries (including Coos, Yaquina, and Willapa Bays), oysters provide commercially important shellfish production and important ecosystem function, such as filtration of particulates from the water. Seagrasses provide critical habitats that serve as nurseries for estuarine fishes and crabs. Additionally, seagrasses and tidal marshes are important bird and juvenile salmon habitats. The interaction between freshwater flow into an estuary and seawater from the ocean creates a salinity regime that is vital to the existence of these critical habitats.

As a part of the overall research effort, hydrological models were commissioned for four estuaries in Oregon and Washington coastal areas: South Slough of Coos Bay, Coquille River estuary, Willapa Bay, and Yaquina Bay (fig. 1). These estuaries were selected because they represent a range of estuary types, from a marine-dominated estuary (South Slough of Coos Bay) to a highly riverdominated estuary with a large watershed (Coquille River estuary), providing insight into how climatic drivers may alter different estuarine environments. Although the larger project is focused on estuaries, the models were developed for the entire area that drains to each estuary (that is, its watershed). Note that in two cases (Willapa Bay and Coos Bay South Slough), several small streams or rivers drain into a single estuary. In the models, we treated all such multi-tributary watersheds as single watersheds, and refer to them as such in this report.

These hydrological models were developed to improve our understanding of how freshwater inflows to these estuaries may shift under climate change. Such shifts could be important, as they may cause changes in estuarine salinity, water quality (Scavia and others, 2002), the distribution of habitat and health aquatic species (Roessing and others, 2004; Levinton and others, 2011), and lead to increases in the spread of invasive species (Stachowicz and others, 2002; Winder and others, 2011).

Different types of estuaries (marine- versus river-dominated) will have differing responses to changes in freshwater inflow. Salinity is an important factor in estuaries that influences the distribution of organisms as well as physical properties, such as stratification and mixing. Studies in other regions have demonstrated that climate change has the potential to influence estuarine salinity (Gibson and Najjar, 2000; Hilton and others, 2008). Climate change may influence the salinity distribution of estuaries, primarily through changes in freshwater inflow and rising sea level. The importance of each of these drivers on estuarine salinity will vary depending on season and location within an estuary. Declines in the freshwater inflow during the low-flow period may result in increased intrusion of saltwater up the estuary and increased water residence time, which can affect water quality. Such changes can influence the distribution of estuarine organisms. For example, Levinton and others (2011) show that changes in precipitation and resulting freshwater associated with climate change may result in increased mortality of oysters.

Freshwater inflow to estuaries can influence other key water-quality conditions. For instance, dissolved oxygen (DO) is an important water-quality metric because of its effects on the well-being of 
resident and transitory estuarine organisms, particularly salmonids. The State of Oregon DO criterion for estuaries $(6.5 \mathrm{mg} / \mathrm{L})$ is based on a review of physiological requirements of biota, and is high compared to DO criteria for other estuaries (U.S. Environmental Protection Agency, 2003). A review of the DO criterion found that $6.5 \mathrm{mg} / \mathrm{L}$ may be difficult to achieve in Oregon estuaries during the summer because of natural conditions (Oregon Department of Environmental Quality, 1995). There have been occurrences of severe hypoxia on the inner continental shelf of Oregon (Grantham and others, 2004; Chan and others, 2008). This low-oxygen water is periodically advected into PNW estuaries (Brown and Power, 2011; Roegner and others, 2011). Declines in freshwater inflow during the low-flow period combined with sea level rise may result in increased intrusion of low-oxygen water into the estuaries, whereas in upriver parts of the estuaries, dissolved oxygen levels also may be influenced by climate change through increased stratification, reduced flushing, as well as temperature effects.

Another important factor for water quality in PNW estuaries is bacterial impairment, which can affect commercial aquaculture and can be influenced by climate change. As an example, high concentrations of fecal coliform in the Tillamook estuary (indicator of fecal contamination) in autumn were preceded by dry conditions and high intensity rainfall (Sullivan and others, 2005). Climate projections for the PNW suggest that there may be decreases in summer precipitation and increases in winter precipitation. With this projected change in precipitation pattern, it is possible that there may be higher fecal coliform levels during autumn and early winter if there are sources in the watershed.

\section{Study Area}

Figure 1 shows locations of the watersheds draining to each of the four study estuaries, and table 1 gives basic facts about each watershed. Estuary type information is from Lee and Brown (2009), and other facts were derived from a 30-m USGS DEM (Digital Elevation Model). In the PNW region, rainfall is highly seasonal, with more than 75 percent of precipitation falling between October and March. Temperatures are mild in these coastal watersheds because they are near the ocean, so most precipitation falls as rain, even in winter.

Figure 2 shows the Land Use-Land Cover (LULC) in each watershed according to the 2001 USGS National Land Cover Dataset (NLCD); evergreen forests are the predominant land cover class in all four watersheds, ranging from 36 to 60 percent of total area. All watersheds include some developed land, ranging from 5 to 10 percent of total area. Figure 3 shows the basic geological profile of each watershed. Throughout most of this region, marine sedimentary rocks, which have limited permeability, are the dominant type.

\section{Coos Bay South Slough Estuary and Watershed}

The Coos Bay South Slough watershed, the smallest of the four study watersheds with an area of $74.3 \mathrm{~km}^{2}$, is located on the southern Oregon Coast (fig. 1). The study area is the watershed draining only into the South Slough of Coos Bay; most of Coos Bay is not modeled. Coos County, which contains the bay, has an economy primarily based on fish, lumber, and shellfish harvests. Although there are no towns or cities within the South Slough watershed, the cities of Coos Bay (population 15,967) and North Bend (population 9,695) (U.S. Census Bureau, 2011), are located within $5 \mathrm{~km}$ of the study area on the northern shores of Coos Bay. In 1974, the Coos Bay South Slough was declared the nation's first National Estuarine Research Reserve, and research on estuaries and how to restore them has been conducted there ever since (Oregon Coastal Management Program, 2011b). As shown in figure 3, this watershed has a greater percentage of sedimentary rocks than any of the other watersheds. There are no dams or diversions within the watershed (Falk and Robison, 2010). 


\section{Modeled Watersheds}
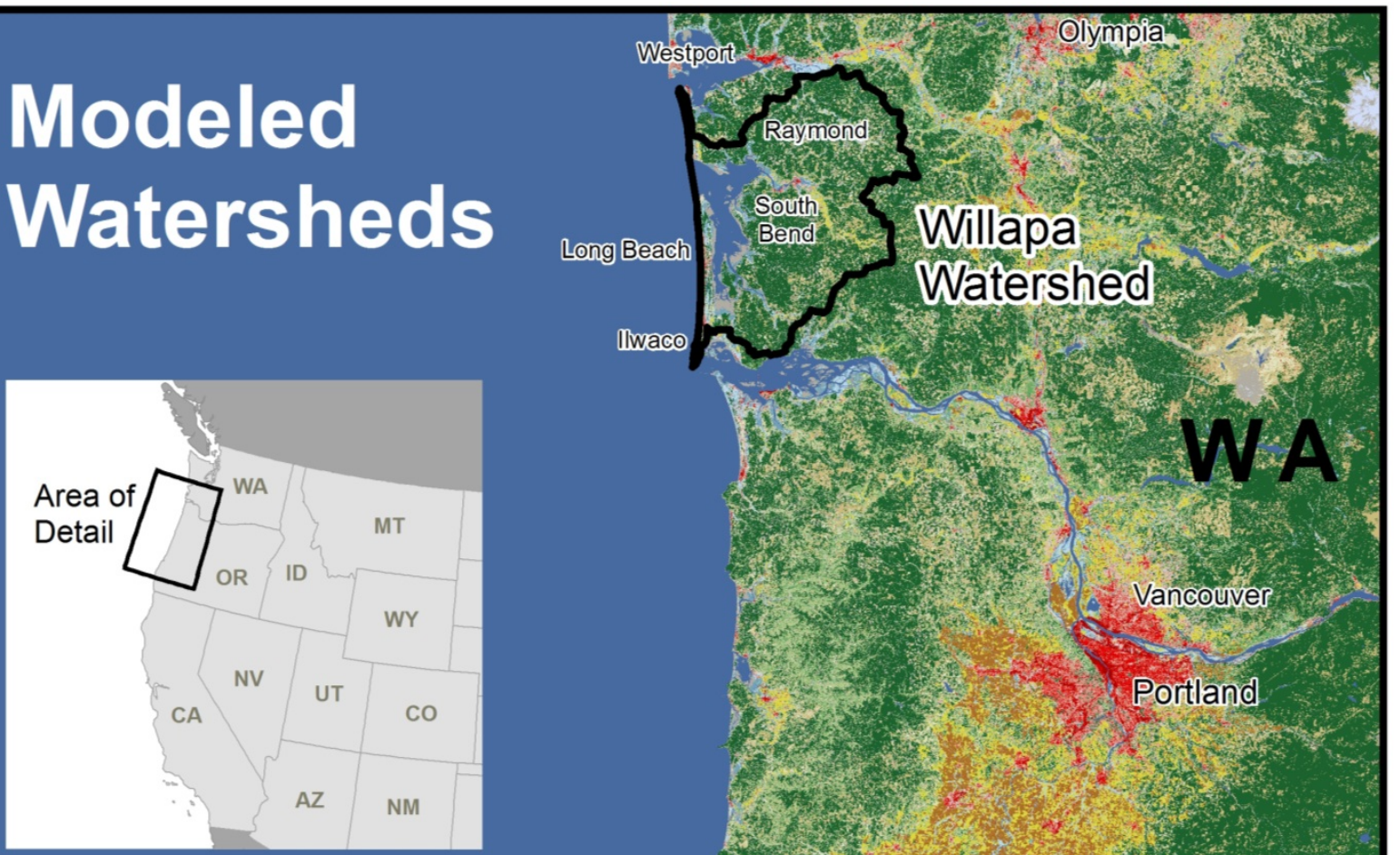

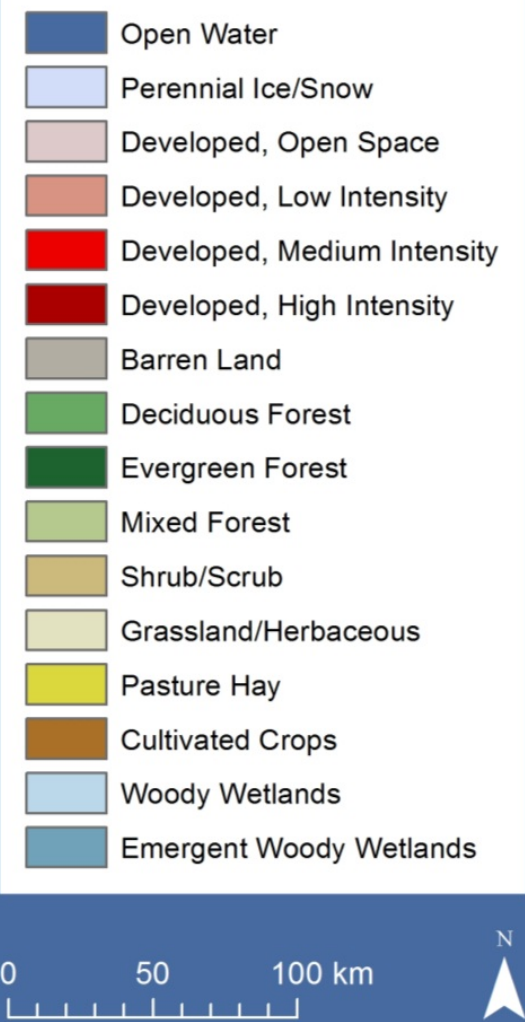

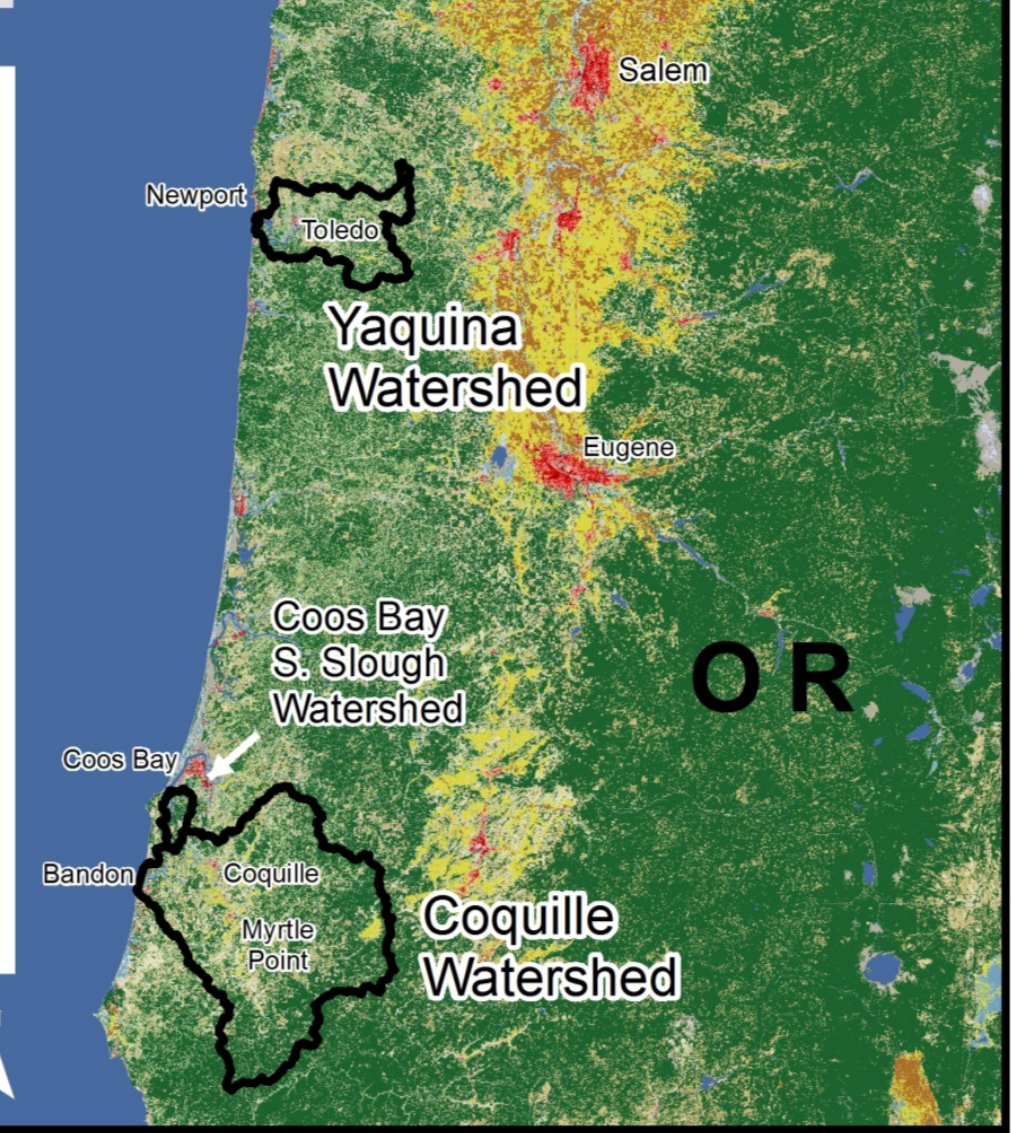

Figure 1. Location of four study-area watersheds, Washington and Oregon, with National Land Cover Dataset, 2001. Watershed boundaries are from the USGS National Hydrography Dataset. Projection is WGS 1984 Web Mercator. Locator inset data is from Natural Earth, with NAD 1983 North America Albers Equal Area Conic. 


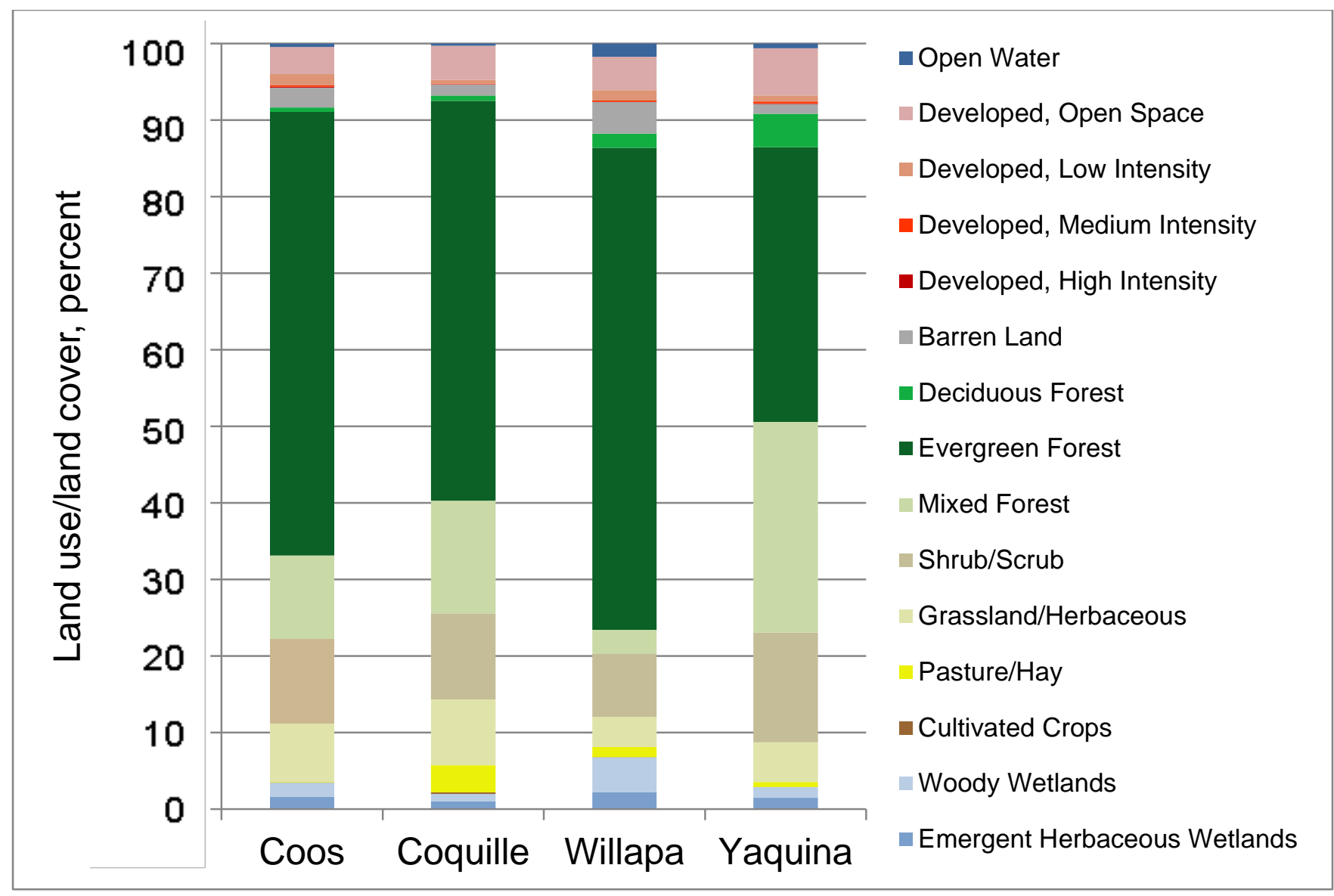

Figure 2. U.S. Geological Survey National Land Cover Dataset Land Use-Land Cover composition in each of the four study-area watersheds, Oregon and Washington, 2001.

\section{Coquille River Estuary and Watershed}

The Coquille River estuary is at the mouth of the Coquille River, which drains a large watershed in southwest Oregon (fig. 1). As in Coos Bay, the primary economic foundations of the area are fishing and lumber, but dairy farming and other forms of agriculture also are common (Coquille Watershed Association, 2011). The 2,747.6 $\mathrm{km}^{2}$ watershed primarily is in Coos County, but small parts also are in Douglas and Curry Counties. The watershed contains three cities: Coquille (population 3,866), Myrtle Point (population 2,514), and Powers (population 689). It also includes parts of Bandon (population 3,066) near the Coquille River estuary (U.S. Census Bureau, 2011).

Of the four study estuaries, the Coquille River estuary has the largest watershed and the strongest riverine influence. Nevertheless, saltwater penetrates the Coquille River, and tidal head has been observed as far as $41 \mathrm{mi}$ upstream of the river's mouth (Oregon Coastal Management Program, 2011a). The watershed contains two major dams. Major dams have a height greater than or equal to 50 $\mathrm{ft}(15 \mathrm{~m})$, a normal storage capacity greater than or equal to 5,000 acre-feet $\left(6,200,000 \mathrm{~m}^{3}\right)$, or a maximum storage capacity greater than or equal to 25,000 acre-feet $\left(31,000,000 \mathrm{~m}^{3}\right)$. Combined, the two major dams have a normal storage capacity of 330 acre-feet $\left(410,000 \mathrm{~m}^{3}\right)$ (National Atlas of the United States, 2006). 


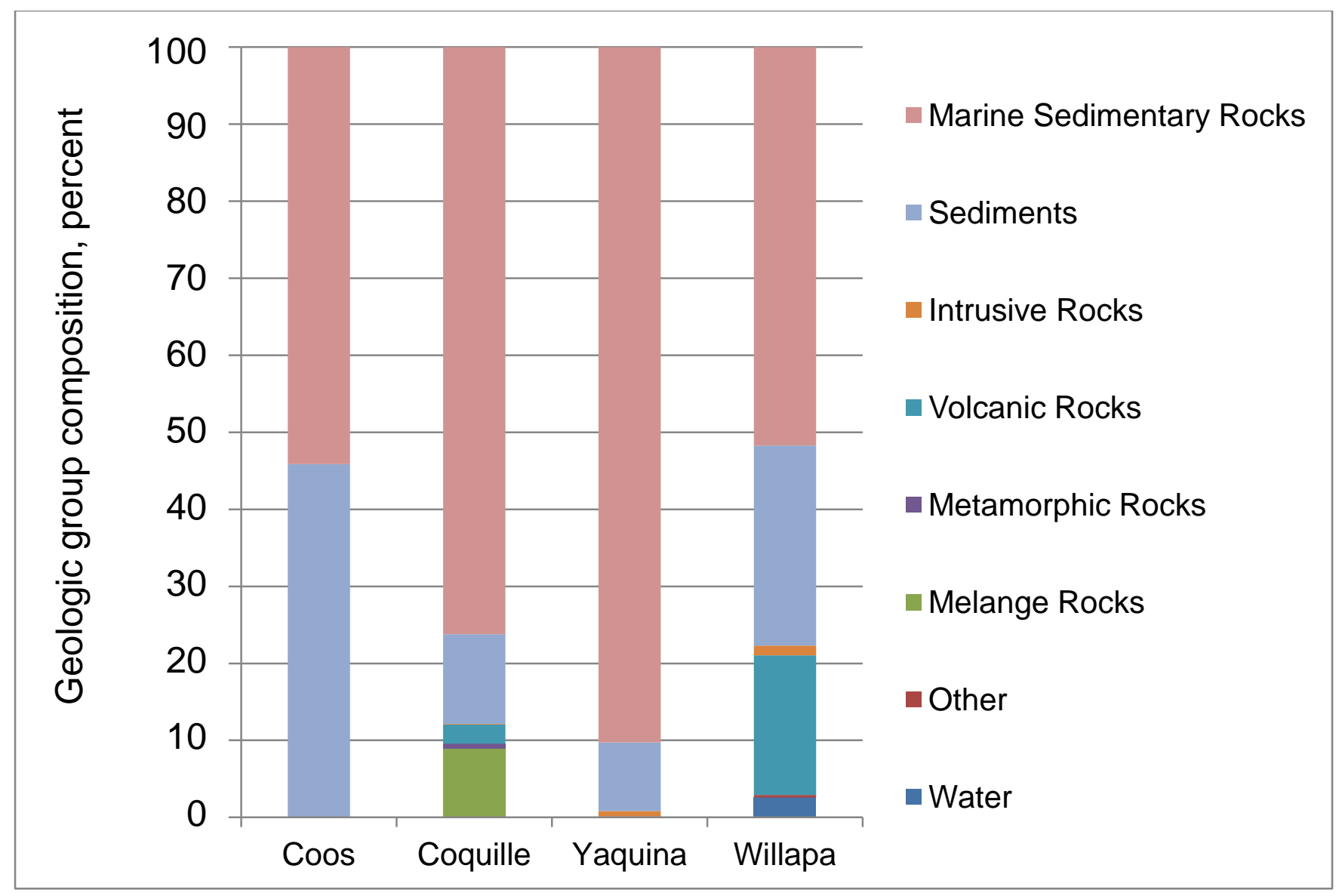

Figure 3. Terrine or geologic group composition in each of the four study-area watersheds, based on Oregon Geologic Data Compilation (Ma and others, 2009).

Table 1. Watershed area, estuary type, elevation, and slope for the four study-area watersheds.

\begin{tabular}{lcccc}
\hline \multicolumn{1}{c}{ Watershed Name } & $\begin{array}{c}\text { Area } \\
\left(\mathbf{k m}^{2}\right)\end{array}$ & Estuary type & $\begin{array}{c}\text { Mean elevation } \\
(\mathbf{m})\end{array}$ & $\begin{array}{c}\text { Mean slope } \\
\text { (percent) }\end{array}$ \\
\hline Coos Bay South & 74.3 & Marine-dominated & 194 & 17.7 \\
Slough & & River-dominated & 1,179 & 35.0 \\
Coquille River & $2,747.6$ & Marine-dominated & 147 & 24.2 \\
Willapa Bay & $2,484.8$ & Marine-dominated & 482 & 31.3 \\
Yaquina Bay & 650.7 & & & \\
\hline
\end{tabular}

\section{Willapa Bay Estuary and Watershed}

Willapa Bay is the second largest estuary on the Pacific Coast of the United States, and is home to the Willapa National Wildlife Refuge, which hosts more than 100,000 shorebirds during the spring migration (U.S. Fish and Wildlife Service, 2011). Willapa Bay's 2,484.8 $\mathrm{km}^{2}$ watershed contains three cities: Raymond (population 7,892), South Bend (population 1,637), and Long Beach (population 1,392) (U.S. Census Bureau, 2011). The watershed also contains parts of the cities of Westport (population 6,661) and Ilwaco (population 936), as well as many unincorporated communities. There is one major dam in the watershed, with a normal storage of 846 acre-feet $\left(1,000,000 \mathrm{~m}^{3}\right)$ (National Atlas of the 
United States, 2006). As in all PNW coastal watersheds, timber plantations are a major part of the economy. Oyster production is especially important here (Wolf, 1993).

\section{Yaquina River Estuary and Watershed}

The 676.6-km² Yaquina watershed is drained by the Yaquina River and its major tributary, Big Elk Creek, which enter the Pacific Ocean at Yaquina Bay. The watershed contains parts of Newport (population 9,989), all of Toledo (population 3,465) (Oregon Department of Transportation, 2009; U.S. Census Bureau, 2011), and several other communities. Major economic activities include lumber, fishing, tourism, and agriculture (Ame, 2007). At the mouth of the river, Yaquina Bay supports an estuary with an area of $17.5 \mathrm{~km}^{2}$, which provides critical spawning, breeding, and nesting habitat for many species, including endangered and threatened salmonids (Bauer and others, 2011). The Yaquina estuary is a drowned river mouth estuary (Oregon Coastal Management Program, 2011c) and is tidedominated (Lee and Brown, 2009). There are two major dams in the watershed (National Atlas of the United States, 2006).

\section{Data}

\section{Geographic Information System (GIS) Data}

Our analysis involved the use of data from numerous GIS sources, as listed in table 2. We used several GIS layers to create hydrologic response units (HRUs), or areas where the hydrologic response is assumed to be the same, for use in the Precipitation Runoff Modeling System (PRMS). We also used GIS to estimate parameter values for each HRU as explained in the "Methods" section.

Table 2. Geographic Information System data sources.

\begin{tabular}{|c|c|}
\hline Data source & Resolution \\
\hline 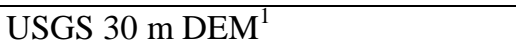 & $30 \mathrm{~m}$ pixels \\
\hline USGS 2001 LULC $^{1}$ & $30 \mathrm{~m}$ pixels \\
\hline USGS 2001 Percent Impervious & 30 m pixels \\
\hline DOGAMI Oregon Geology ${ }^{1}$ & Varies from $1: 12,000$ to $1: 500,000$ \\
\hline Washington State Surface Geology ${ }^{1}$ & $1: 100,000$ \\
\hline NRCS SSURGO soil data ${ }^{1}$ & Varies from $1: 12,000$ to $1: 63,360$ \\
\hline $\begin{array}{l}\text { CIG (Climate Impacts Group) } \\
\text { historical climate data grid }\end{array}$ & 1/8 degree grid (lat-long) \\
\hline
\end{tabular}

\section{Flow Data}

To calibrate and test a PRMS model, a daily flow record is required. A flow record of 20-30 years is ideal for model calibration and validation, and the minimum data requirement is about 6-7 years. Flow records were not available for the mouths of any of the four watersheds of interest. Therefore, for each watershed, we identified a suitable gaged calibration sub-watershed or similar neighboring watershed, and used its flow record to develop the model. This process will be described in more detail in "Methods." The four streamflow-gaging stations used are listed in table 3. 
Table 3. Streamflow-gaging stations used in model calibration.

\begin{tabular}{lcccc}
\hline \multicolumn{1}{c}{ Watershed } & $\begin{array}{c}\text { Gaging station } \\
\text { No. }\end{array}$ & $\begin{array}{c}\text { Record length } \\
\text { (years) }\end{array}$ & Calibration period & Verification period \\
\hline Coos Bay South Slough & OWRD 14324590 & 14 & $1982-1991$ & $1991-1996$ \\
Coquille River & USGS 14325000 & 28 & $1970-1984$ & $1984-1998$ \\
Yaquina Bay & USGS 14306030 & 19 & $1972-1982$ & $1982-1991$ \\
Willapa Bay & USGS 12010000 & 30 & $1970-1985$ & $1985-2000$ \\
\hline
\end{tabular}

\section{Historical Climate Data}

Other required data for hydrologic modeling included historical minimum temperature (TMIN), maximum temperature (TMAX), and total precipitation (PRECIP) at a daily time step. For these inputs, we used the synthetic weather grid data prepared by the Climate Impacts Group (CIG), University of Washington, as a part of the Columbia Basin Climate Change Scenarios Project (CBCCSP) (Hamlet and others, 2010). The gridded data, hereafter referred to as CIG data, are based on the Parameter-elevation Regressions on Independent Slopes Model (PRISM), which is an interpolation of historical station data with consideration of orographic effects, temperature inversions, and coastal effects (Daly and others, 2002; Salathe and others, 2007; PRISM Climate Group, 2012). CIG data points inside of or within $5 \mathrm{~km}$ of each calibration sub-watershed were averaged into a single data file.

This approach has several advantages. Most importantly, climate inputs are representative of the entire sub-watershed, avoiding errors associated with generalization from a few weather stations to a large area. Orographic effects, which are considered in the CIG data, are especially important in mountainous and complex terrain such as that of the Coast Range. CIG data also have no gaps, so patching was not required, and the CIG period of record is long (1915-2006). Finally, using CIG historical climate data to calibrate all four coastal watershed models improved model comparability, because the smallest watersheds had no good candidates for historical weather stations, and had to be calibrated with CIG data. To confirm that the CIG data accurately reflected the historical record in our study areas, we selected nine weather COOP (COoperative Observer Program) stations that were inside of or within $10 \mathrm{~km}$ of the four calibration sub-watersheds (COOP ID 350471, 354133, 356820, 358182, 358494, 358833, 453333, 455774, and 456914). We then compared PRECIP, TMAX, and TMIN values from each station to the values from its closest CIG grid point. Across the nine stations, the mean coefficients of determination $\left(\mathrm{R}^{2}\right)$ from simple linear regressions for PRECIP, TAMX, and TMIN were 0.92, 0.97, and 0.99, respectively. This high level of fit supported the decision to use the CIG data.

\section{Future Climate Scenarios}

The other key datasets in this analysis were the future climate scenario outputs. We selected scenarios from the North American Regional Climate Change Assessment Program (NARCCAP) to increase compatibility with other aspects of the larger project on estuaries and climate change, and because they are state-of the-art scenarios. These climate change simulations are produced by embedding Regional Climate Models (RCMs) within global-scale Atmosphere-Ocean General Circulation Models (AOGCMs) (North American Regional Climate Change Assessment Program, 2011a). By combining the models, the resolution of the outputs is improved greatly over those of an 
AOGCM alone. Outputs from an AOGCM and an AOGCM-RCM pair are shown in figure 4. The enhanced resolution is especially apparent over the Rocky Mountains.

\section{CCSM Change in Average Winter (December, January, February) Surface Temperature, Degrees Celcius}
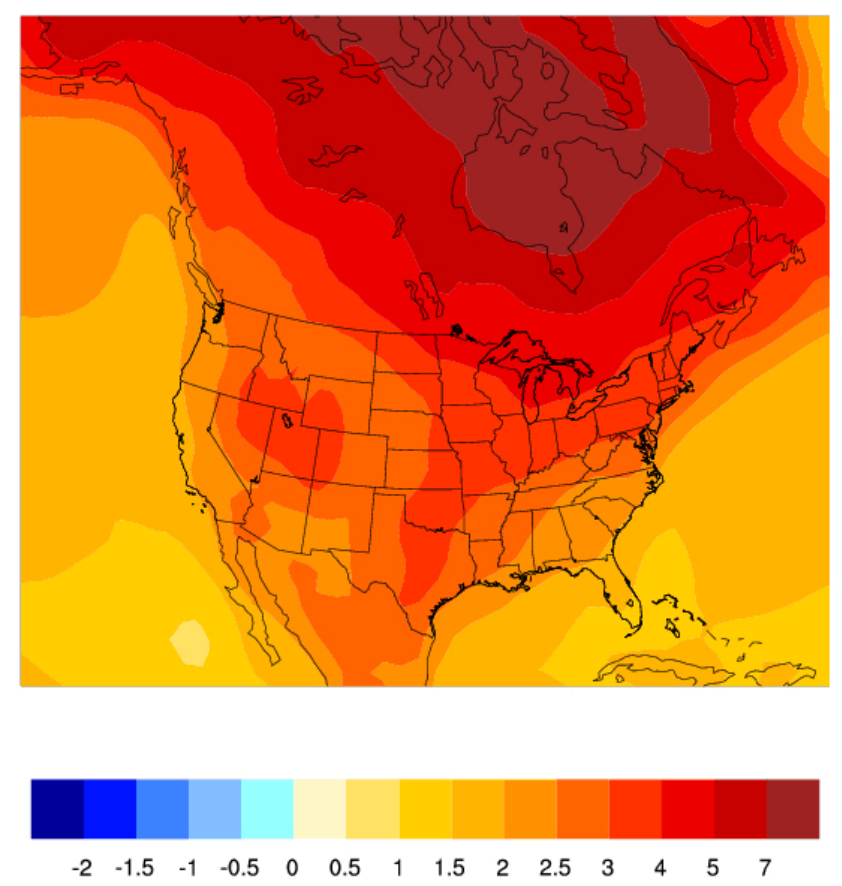
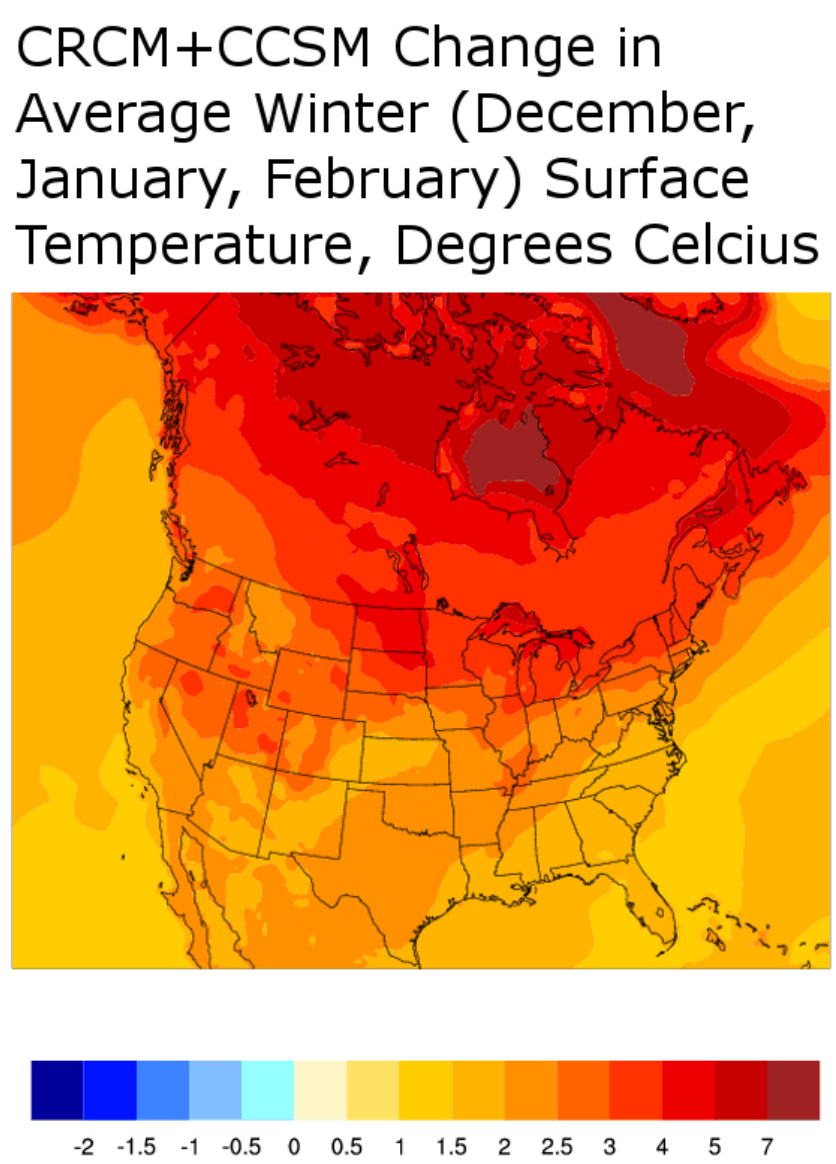

Figure 4. Examples of North American Regional Climate Change Assessment Program scenario outputs. Outputs from an Atmosphere-Ocean General Circulation Model (AOGCM) are shown on the left, and outputs from an AOGCM-Regional Climate Model (RCM) pair are shown on the right (North American Regional Climate Change Assessment Program, 2011b).

Because of limited resources, the NARCCAP focuses on developing as many AOGCM-RCM pairs as possible, rather than using multiple carbon emissions scenarios. The NARCCAP selected a single emission scenario, A2, which is at the higher end of the emissions scenarios, though it is not the highest. Like the other carbon emission scenarios commissioned by the Intergovernmental Panel on Climate Change, it is described in Nakicenvoic and others (2000). NARCCAP researchers argue that selecting a single high-emission scenario is reasonable because if we plan for extreme circumstances, we will also be prepared for moderate changes. The recent trajectory of carbon emissions (1990 to 2011) also best fits a fairly high emission scenario (North American Regional Climate Change Assessment Program, 2011c). Although the NARCCAP eventually will release many different AOGCM-RCM simulations, at the time of this research (2012) only four were completed for our reference period (1971-1995) and a future period (2041-2065). These simulations are listed in table 4. We did not force the models with the ensemble mean, because this masks the variability of each scenario, and we were interested in seeing a range of possible future outcomes. Daily data for each 
watershed were extracted from the North American Regional Climate Change Assessment Program web site by Darrin Sharp at the Oregon Climate Change Research Institute (OCCRI), Oregon State University. All the data points within a bounding box for each watershed were averaged to produce mean values for that watershed. Parameters used were TASMAX/TASMIN (maximum and minimum daily surface air temperature) and PRECIP (precipitation). The precipitation value was reported every 3 hours, and had to be aggregated and averaged to compute a daily value.

Table 4. North American Regional Climate Change Assessment Program climate scenarios used to force Precipitation Runoff Modeling System models.

\begin{tabular}{|c|c|c|}
\hline Acronym & Regional Climate Model (RCM) & $\begin{array}{l}\text { Atmosphere-Ocean General } \\
\text { Circulation Model (AOGCM) }\end{array}$ \\
\hline CRCM_CCSM & Canadian Regional Climate Model (Canada) & $\begin{array}{l}\text { NCAR Community Climate Model } \\
\text { version } 3 \text { (United. States.) }\end{array}$ \\
\hline CRCM_CGCM3 & Canadian Regional Climate Model (Canada) & $\begin{array}{l}\text { Canadian Global Climate Model } \\
\text { version } 3 \text { (Canada) }\end{array}$ \\
\hline HRM3_HADCM3 & Hadley Regional Model version 3 (United Kingdom) & $\begin{array}{l}\text { Hadley Centre Climate Model } \\
\text { version } 3 \text { (United Kingdom) }\end{array}$ \\
\hline RCM_CGCM3 & $\begin{array}{l}\text { Regional Climate Model produced by University of California at } \\
\text { Santa Cruz, version } 3 \text { (United. States.) }\end{array}$ & $\begin{array}{l}\text { Canadian Global Climate Model } \\
\text { version } 3 \text { (Canada) }\end{array}$ \\
\hline
\end{tabular}

Figures 5 and 6 show the changes in maximum daily temperature and total daily precipitation from the reference period to the future period in an example watershed (Yaquina Bay watershed). All four scenarios show increasing mean temperatures from the reference period to the future period (fig. 5), with CRCM-CGCM3 and HRM3-HADCM3 showing larger increases in summer. However, there is much less consistency in modeled changes in precipitation (fig. 6). In most months, some models show decreases in precipitation, and some show increases. Only in August and November is there agreement as to the direction of change. Changes in input data from the reference period to the future period vary among the watersheds, but this pattern of greater consistency in temperature than precipitation is present in all four study areas. Because the relation between precipitation and flow is direct in these lowpermeability, rain-dominated watersheds, such discrepancies in predicated precipitation make it difficult to model future runoff confidently. 


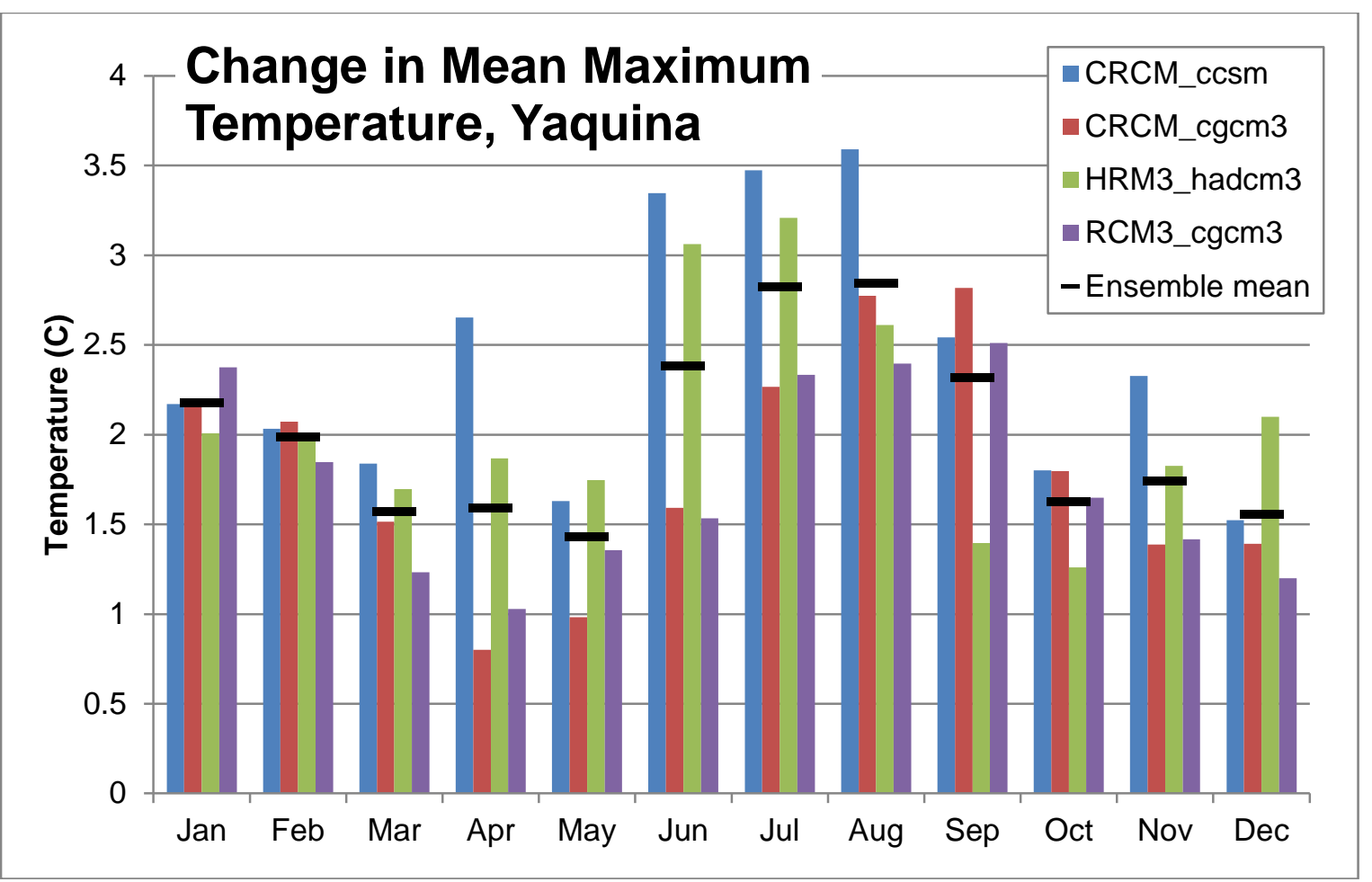

Figure 5. Absolute change in mean maximum daily temperatures from reference period (1971-1995) to future period (2041-2065) by month, in the Yaquina Bay watershed, Oregon.

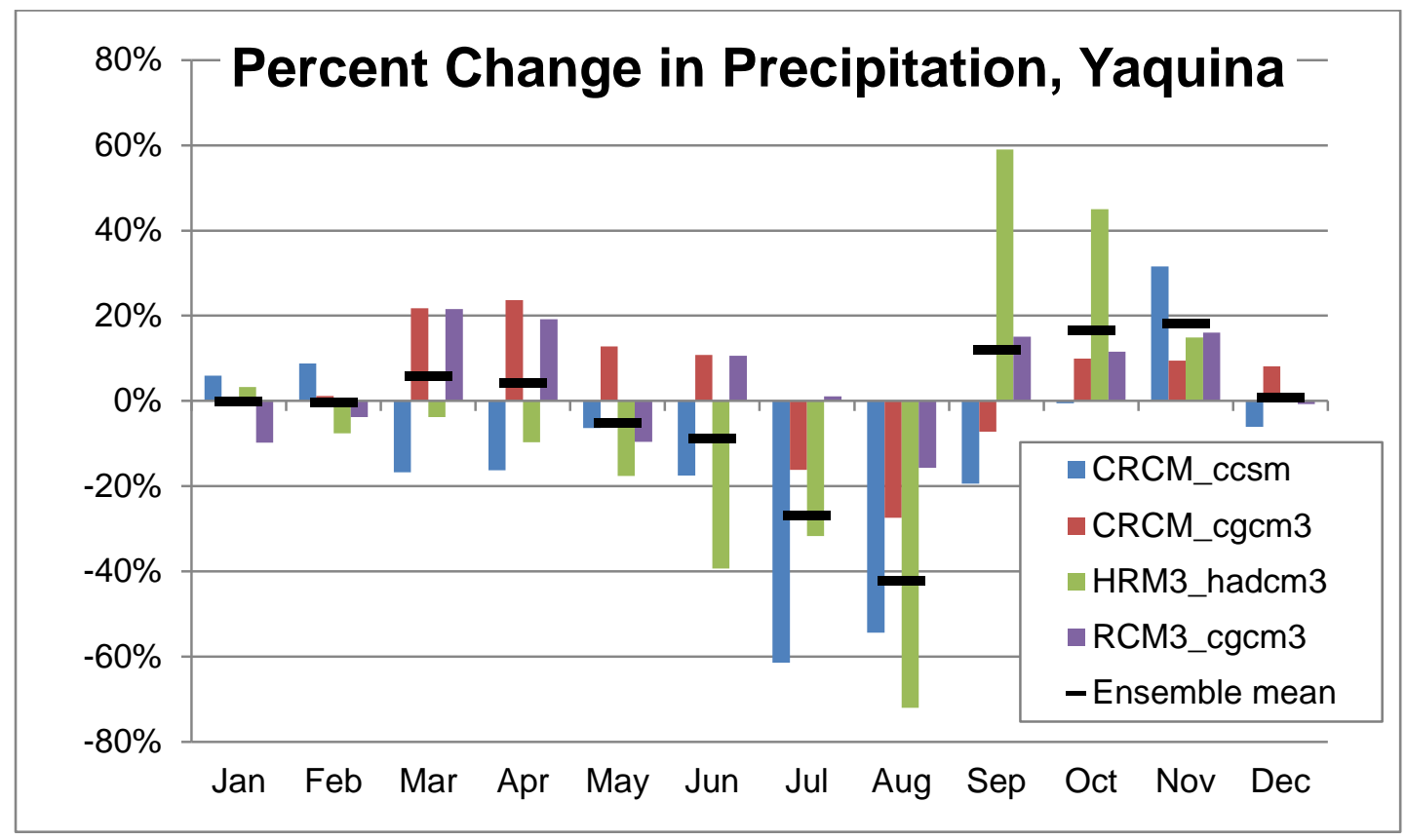

Figure 6. Percent change in mean total daily precipitation from reference period (1971-1995) to future period (2041-2065) by month, Yaquina Bay watershed, Oregon. 


\section{Methods}

\section{Precipitation Runoff Modeling System (PRMS)}

We selected the Precipitation Runoff Modeling System (PRMS) because it has been used in many investigations and regularly improved (Markstrom and others, 2008). PRMS also has been used successfully in climate change impact assessments around the world (for example, Burlando and Rosso, 2002; Legesse and others, 2003; Bae and others, 2007; Qi and others, 2009; Chang and Jung, 2010; Jung and Chang, 2011).

PRMS is a semi-distributed, physically based surface runoff model developed by the USGS (Leavesley and others, 1983; Leavesley and Stannard, 1995). The model is composed of Hydrologic Response Units (HRUs) that are assumed to have a homogeneous hydrological response. PRMS computes a daily water balance for each HRU, and the sums of water and energy balances, weighted by each HRU's relative area, yield daily watershed output values for flow, soil moisture, evapotranspiration, and other variables (Hay and others, 2009). The processes and water storage zones represented by equations in PRMS are shown in figure 7. 


\section{PRMS Model Structure}

\section{Inputs: Precip., Temp., (Solar radiation - optional)}

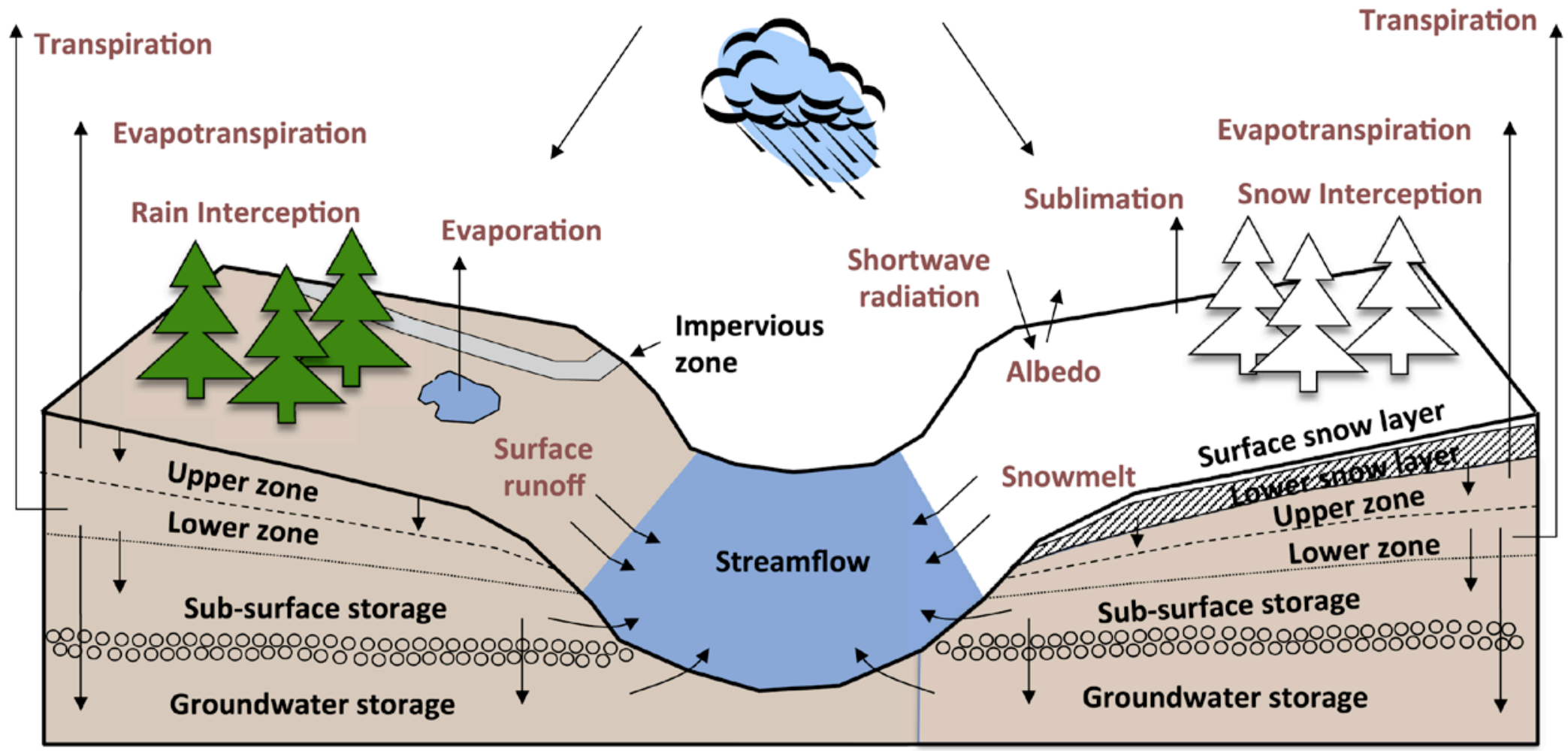

Figure 7. Processes modeled by Precipitation Runoff Modeling System. 


\section{Calibration Flow Gage Selection}

Because only a part of each estuary's watershed was gaged, we used calibration sub-watersheds or neighboring similar watersheds in which the model outputs could be fitted to observed data. The calibrated parameter values then could be transferred to the ungaged watershed of interest. Several previous studies demonstrated the robustness of this approach (for example, Merz and Bloschl, 2004; Kay and others, 2006; Chang and Jung, 2010). When selecting calibration gages, we looked first for gaged sub-watersheds with the largest possible spatial and temporal coverage, and then for nearby watersheds with similar characteristics. We also avoided gages that were downstream of dams or major withdrawals. Calibration sub-watersheds for the Coquille River, Willapa Bay, and Yaquina Bay watersheds are shown in figures 8, 9, and 10. The Coos Bay South Slough watershed had no gaged subwatershed, so we looked for a neighboring gaged watershed that was comparable in land use, elevation, area and other factors, and that had adequate temporal coverage. Selected calibration watersheds are shown in figure 11.

In the remainder of this report, these calibration regions are referred to as "sub-watersheds" to avoid confusion with the estuary watersheds of interest (though note that the Coos Bay South Slough calibration watershed is not a true sub-watershed). The best available flow station for Coos Bay South Slough had a shorter-than-ideal period of record for PRMS (table 3). Additionally, given its location, Coos Bay South Slough may be influenced by marine tides. These two factors, along with the small size of the sub-watershed, make it more difficult to simulate its flow accurately. After identifying the flow gages, we delineated sub-watersheds for each gage and for the entire watershed of interest using a 30-m USGS DEM.

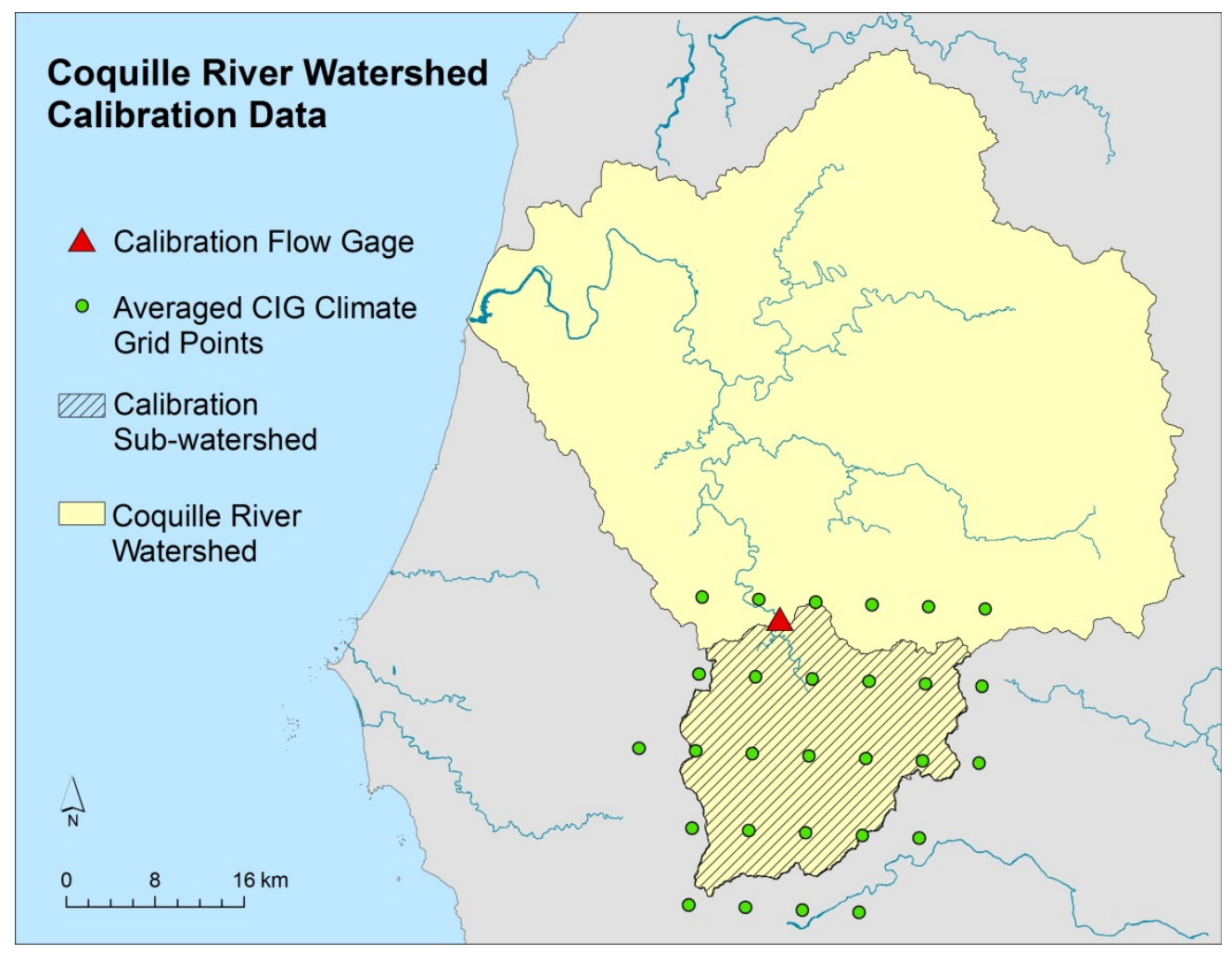

Figure 8. Calibration data for Coquille River watershed, Oregon. 


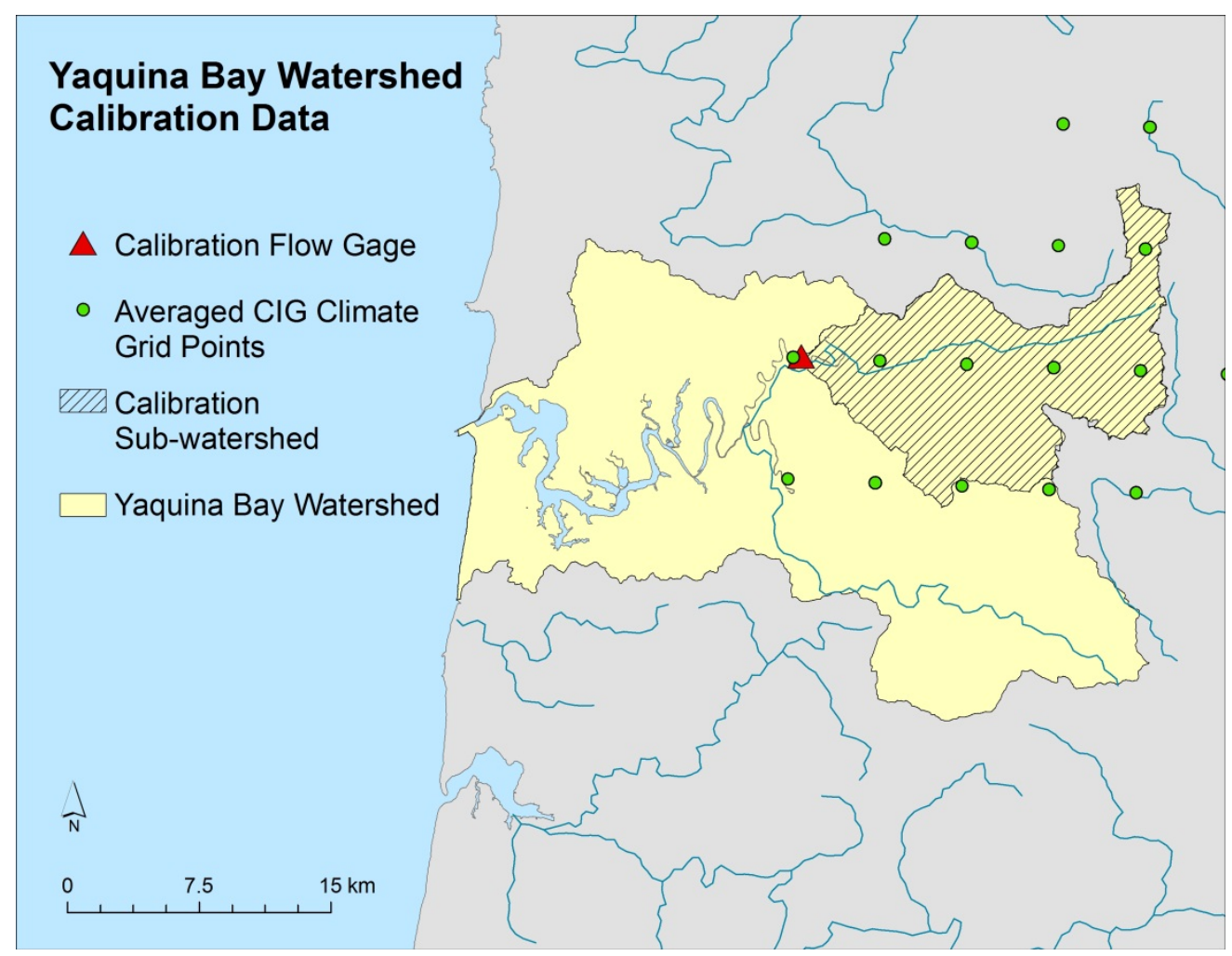

Figure 9. Calibration data for Yaquina Bay watershed, Oregon.

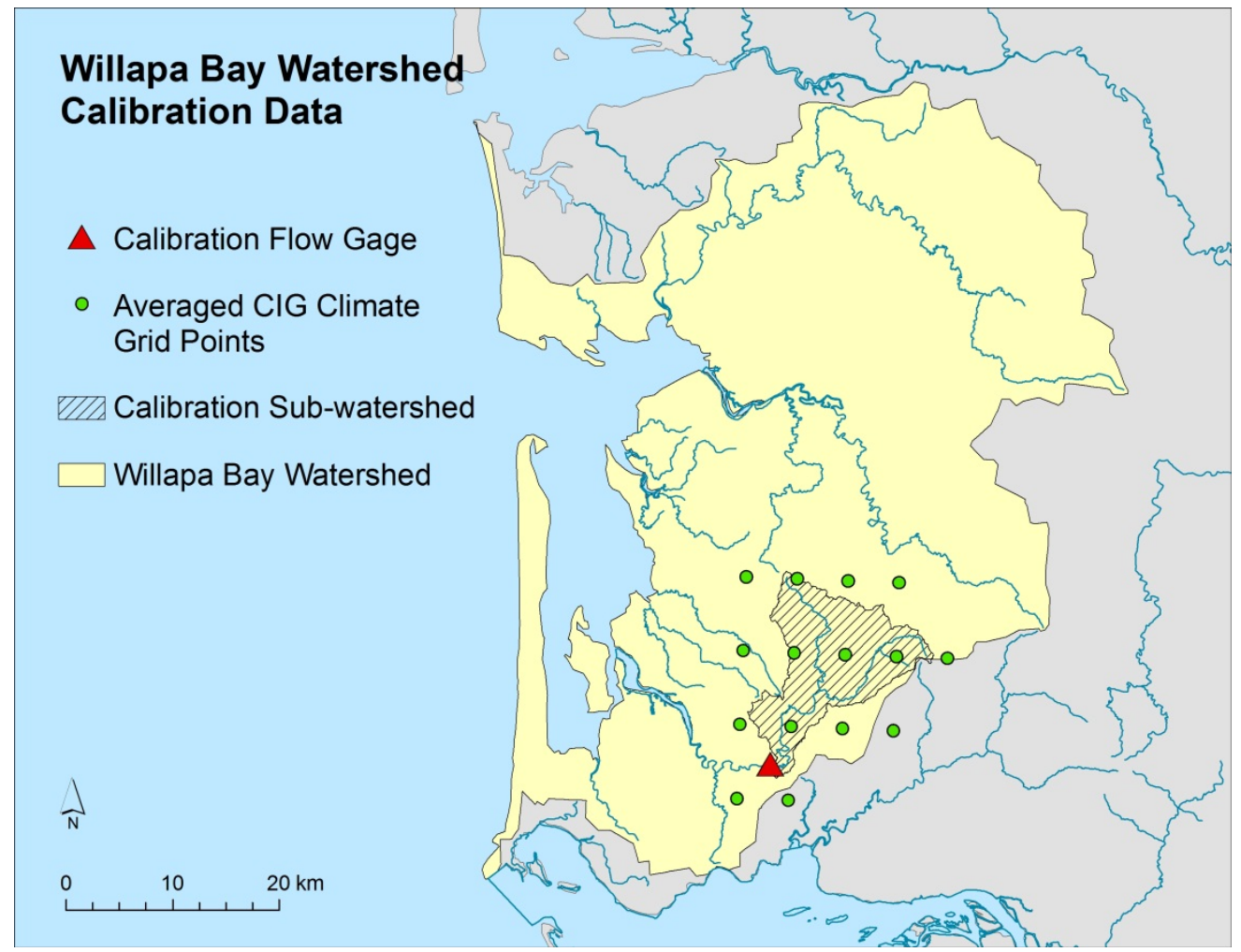

Figure 10. Calibration data for Willapa Bay watershed, Washington. 


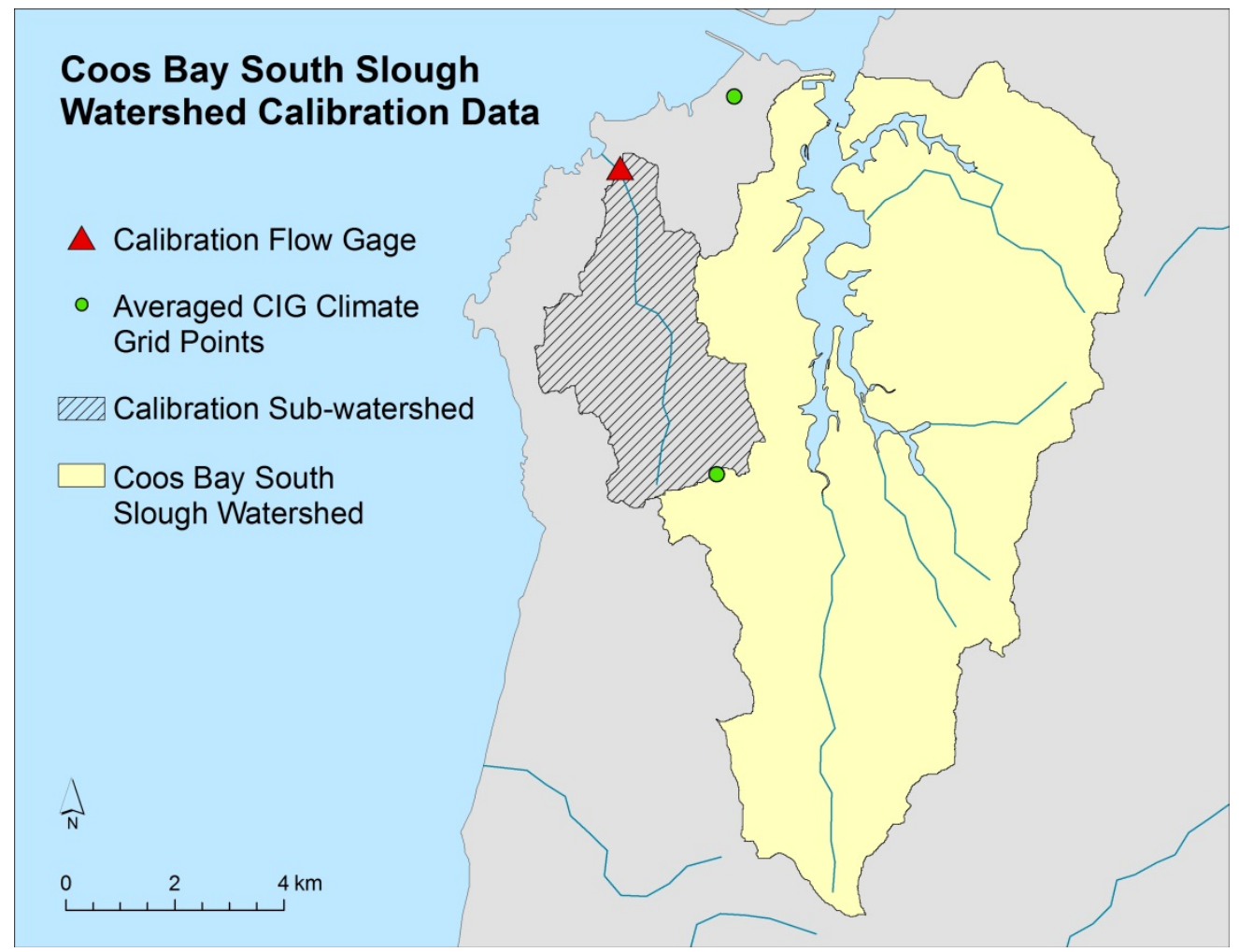

Figure 11. Calibration data for Coos Bay South Slough watershed, Oregon.

\section{HRU Delineation}

With our watershed boundaries identified, the next step was to delineate HRUs. To do so, we made minor modifications to a method described by Leanen and Risley (1997). For their PRMS model of the Willamette River Basin in Oregon, they delineated HRUs based on geology, hydrologic soil group, land use-land cover, and slope and aspect. Slopes were classified as $0-5$ percent, 5-30 percent, and greater than 30 percent. When slopes were greater than 30 percent, they were further subdivided by aspect (north, south, east, or west).

Simplification steps were added to the Leanen and Risley (1997) method because the GIS layers currently available have much higher resolution than those available when the method was developed. Without simplification, tens of thousands of HRUs would be created for each watershed. To a point, increasing the number of HRUs improves accuracy, but above a threshold, model computation (or run) time increases, making it inefficient. We smoothed all input rasters, including slope, aspect, and LULC, with a majority filter. This filter replaces raster cell values based on the majority value of neighboring cells, which results in rasters with larger areas of homogeneity. When rasters are smoothed before they are used to define HRUs, fewer HRUs are ultimately produced. We also merged all HRUs with an area of less than $0.5 \mathrm{~km}^{2}$ into a neighboring HRU. Resulting HRUs are shown in figures 12-15; the number of HRUs in each watershed and calibration sub-watershed are given in table 5. 


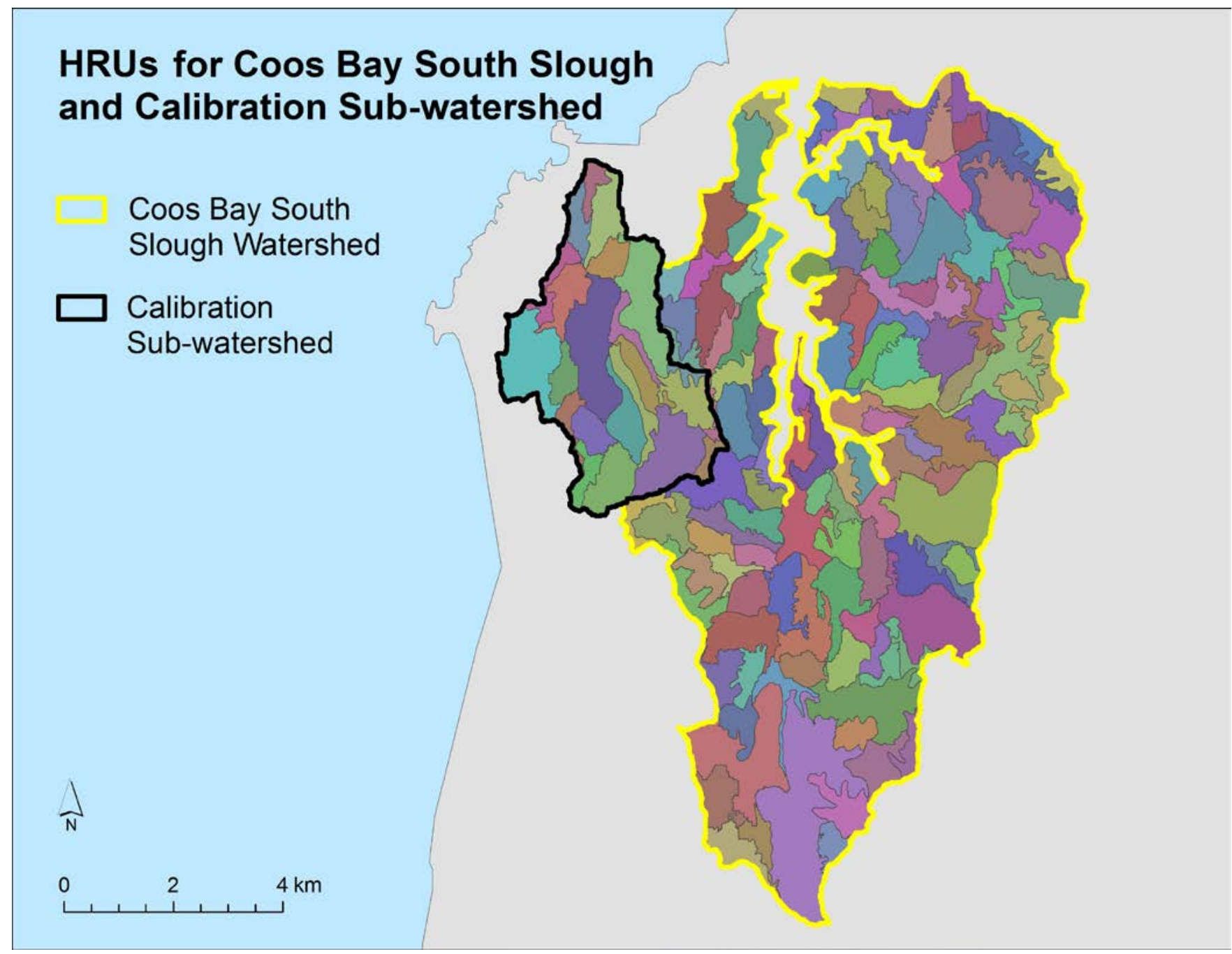

Figure 12. Hydrologic Response Units (HRUs) for Coos Bay South Slough watershed, Oregon. 


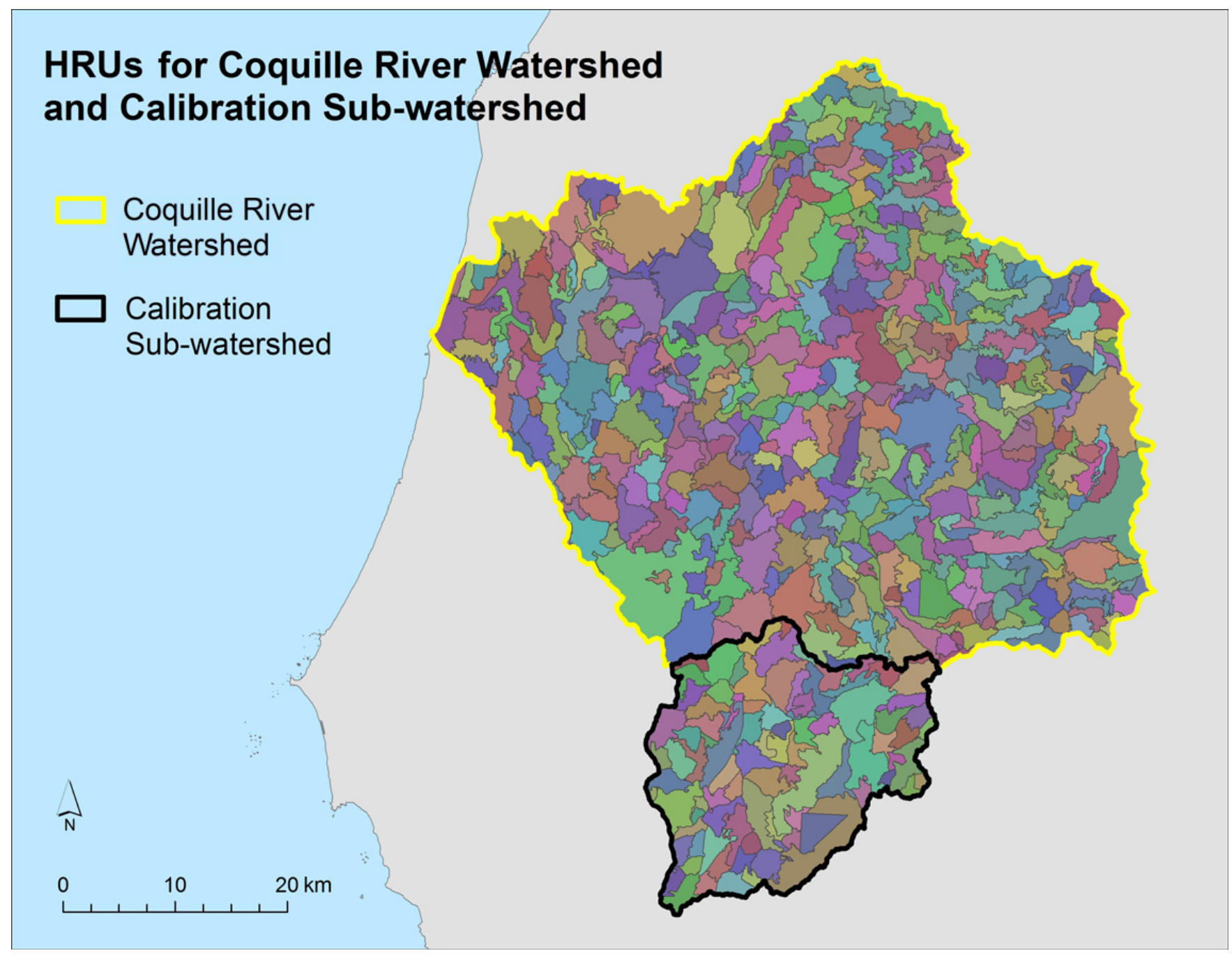

Figure 13. Hydrologic Response Units (HRUs) for Coquille River watershed, Oregon. 


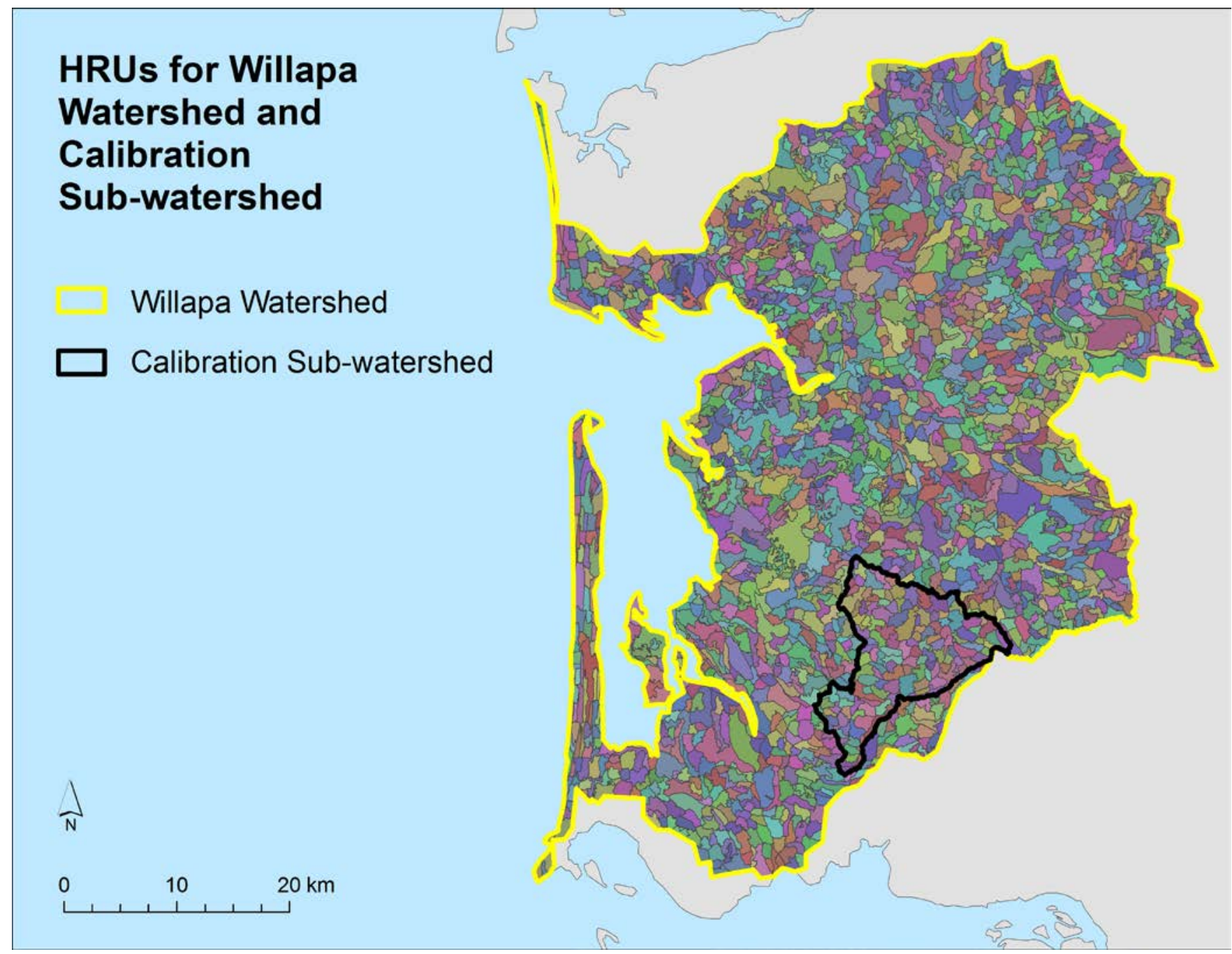

Figure 14. Hydrologic Response Units (HRUs) for Willapa Bay watershed, Washington. 


\section{HRUs for Yaquina Watershed and Calibration Sub-watershed}

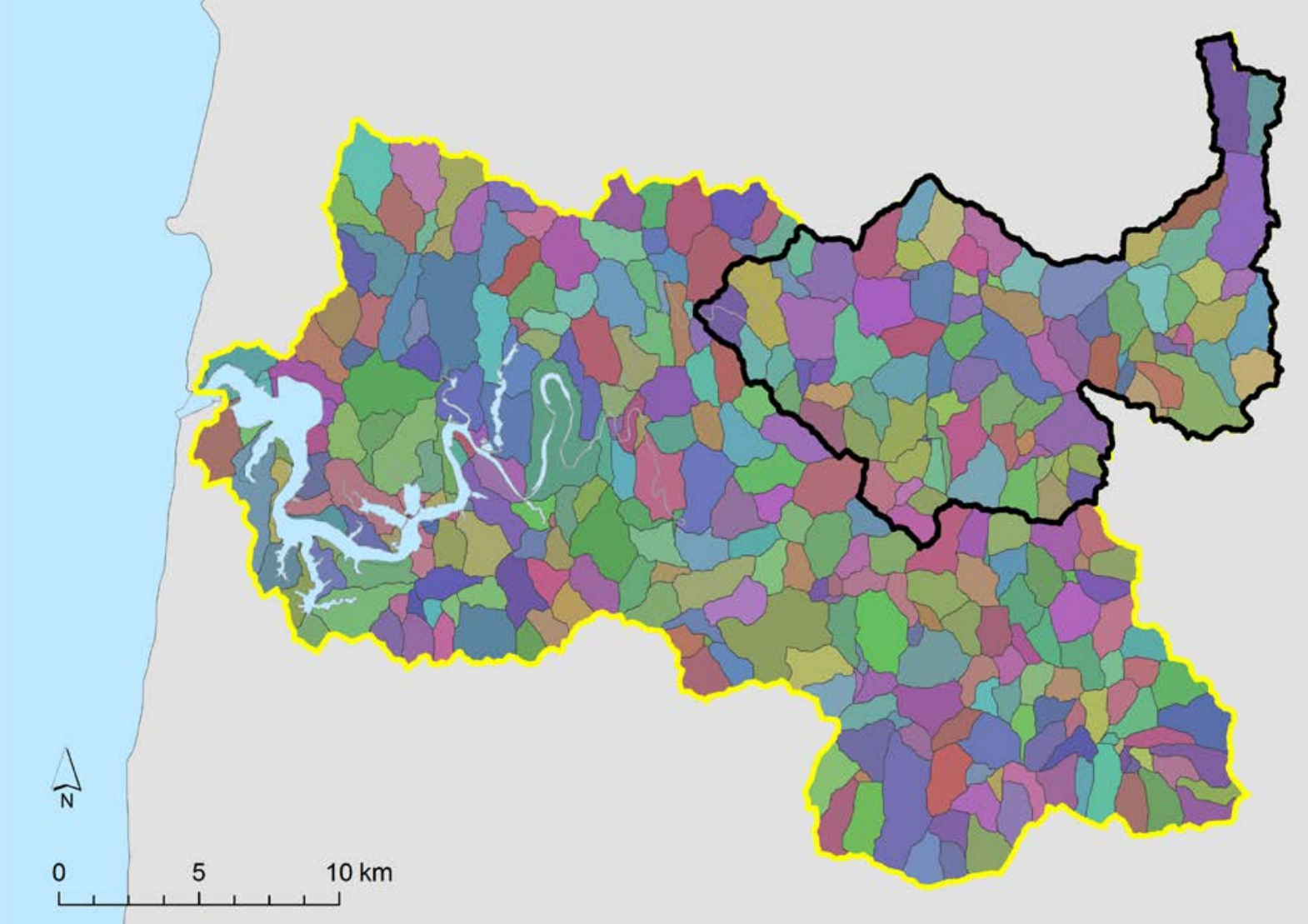

Figure 15. Hydrologic Response Units (HRUs) for Yaquina Bay watershed, Oregon.

Table 5. Number of Hydrologic Response Units (HRUs) in each watershed and calibration sub-watershed. [ $\mathrm{km}^{2}$, square kilometer]

\begin{tabular}{lrccc}
\hline Watershed & \multicolumn{1}{c}{$\begin{array}{c}\text { Area } \\
\left(\mathrm{km}^{2}\right)\end{array}$} & $\begin{array}{c}\text { Area of calibration } \\
\text { sub-watershed }\left(\mathrm{km}^{2}\right)\end{array}$ & $\begin{array}{c}\text { Number of HRUs } \\
\text { in target watershed }\end{array}$ & $\begin{array}{c}\text { Number of HRUs in } \\
\text { calibration sub-watershed }\end{array}$ \\
\hline Coos & 74.30 & 14.05 & 119 & 23 \\
Coquille & $2,747.61$ & 446.40 & 542 & 90 \\
Willapa & $2,484.83$ & 141.86 & 1,953 & 135 \\
Yaquina & 650.65 & 183.26 & 360 & 98 \\
\hline
\end{tabular}

\section{HRU Parameterization}

For many PRMS parameters, such as land cover type and winter rain interception, we derived HRU values using GIS. We followed a detailed procedure on HRU parameterization prepared by the USGS (Lamorey, 2009). This method involves using zonal statistics to derive mean values for each parameter from various layers, many of which were functions of the USGS 2001 LULC layer, Soil 
Survey Geographic (SSURGO) soil data, or a DEM. For example, summer rain interception is calculated for each HRU based on the vegetation density, which is generated from the LULC map. The 20 HRU parameters derived directly or indirectly from GIS layers are listed in table 6. For a full description of the equations and GIS techniques involved in their derivation, see Lamorey (2009). We used static values for the geospatial parameters in reference and future periods, although land cover has changed during the study period, and likely will vary in the future periods. We did not have an LULC layer from the start of the reference period, nor were future LULC scenarios available. It was beyond the scope of the study to prepare such LULC layers, so static parameter values were used.

\section{Model Calibration}

To calibrate the models, we used an iterative approach, and focused on adjusting parameters known to be sensitive in rain-dominated watersheds (U.S. Geological Survey, 2011). After each change, we assessed goodness of fit scores for a calibration period (table 3), reserving data from a verification period for a final evaluation. First, we focused on fitting the overall monthly water balance. Next, we attempted to fit high-flow periods. Finally, we attempted to fit low-flow periods. The parameters used in calibration, and their final value for each sub-watershed, are listed in table 7. Any parameters not listed here or in table 6 were assigned default values or were borrowed from USGS PRMS example models. We used default values for all parameters relating to snow accumulation and melt processes because these parameters are not sensitive in the rain-dominated coastal region. For more information about our calibration methods, see Chang and Jung (2010).

For one calibration sub-watershed, we also made adjustments to the historical CIG precipitation data. Direct manipulation of data inputs is generally not reasonable in hydrological modeling, but in this case, we had evidence that precipitation had been underestimated. A similar approach was used in assessing the effects of climate change on the hydrology of the Columbia River basin (Elsner and others, 2010). Specifically, in the calibration watershed for Willapa Bay, the annual ratio of CIG input precipitation to runoff (the runoff ratio) was 90 percent (table 8). This value is unrealistically high for a watershed with almost no impervious surfaces (Jung and others, 2011).

Table 6. Hydrologic Response Unit parameters derived from Geographic Information System data.

\begin{tabular}{llc}
\hline \multicolumn{1}{c}{ Name } & \multicolumn{1}{c}{ Description } & GIS data source \\
\hline cov_type & Vegetation cover type for each HRU (bare, grass, shrubs, trees) & 2001 USGS National LULC \\
covden_sum & Summer vegetation cover density for each HRU & 2001 USGS National LULC \\
covden_win & Winter vegetation cover density for each HRU & 2001 USGS National LULC \\
hru_aspect & Mean aspect of each HRU & USGS 30 m DEM \\
hru_elev & Mean elevation of each HRU & USGS 30 m DEM \\
hru_lat & Latitude of each HRU & Calculated with ArcMap® \\
hru_percent_imperv & Proportion of each HRU area that is impervious & 2001 USGS National \\
hru_slope & Mean slope of each HRU & Impervious Surface \\
hru_type & Type of each HRU (land, water, swale) & USGS 30 m DEM \\
\hline
\end{tabular}




\begin{tabular}{|c|c|c|}
\hline jh_coef_hru & $\begin{array}{l}\text { Air temperature coefficient used in Jensen-Haise PET } \\
\text { computations for each HRU. }\end{array}$ & 2001 USGS National LULC \\
\hline rad_trncf & $\begin{array}{l}\text { Transmission coefficient for short-wave radiation through the } \\
\text { winter vegetation canopy }\end{array}$ & 2001 USGS National LULC \\
\hline snow_intcp & Snow interception storage capacity for each HRU & 2001 USGS National LULC \\
\hline snow_intcp & $\begin{array}{l}\text { Snow interception storage capacity for the major vegetation type } \\
\text { in each HRU }\end{array}$ & 2001 USGS National LULC \\
\hline soil_moist_max & $\begin{array}{l}\text { Maximum available water holding capacity of soil profile for each } \\
\text { HRU }\end{array}$ & $\begin{array}{l}\text { USDA SSURGO and USGS } \\
\text { LULC }\end{array}$ \\
\hline soil_rechr_max & Maximum value for soil recharge zone for each HRU & $\begin{array}{l}\text { USDA SSURGO and USGS } \\
\text { LULC }\end{array}$ \\
\hline soil_type & HRU soil type (sand, clay, or loam) & USDS SSURGO Soil Maps \\
\hline srain_intcp & Summer rain interception storage capacity each HRU & 2001 USGS National LULC \\
\hline tmax_adj & $\begin{array}{l}\text { Adjustment to max. temp. for each HRU based on slope and } \\
\text { aspect }\end{array}$ & USGS 30 m DEM \\
\hline tmin_adj & Adjustment to min. temp. for each HRU based on slope and aspect & USGS 30 m DEM \\
\hline wrain_intcp & Winter rain interception storage capacity each HRU & 2001 USGS National LULC \\
\hline
\end{tabular}

John Risley of the USGS recommended that we check these findings by estimating annual water budgets for this watershed using PRISM (Parameter-elevation Regressions on Independent Slopes Model) data, mean annual runoff depth from USGS annual data reports, and evapotranspiration estimates from the National Oceanic and Atmospheric Administration evaporation atlas (Farnsworth and others, 1982). We did so, and determined that the runoff ratio was also too high in this estimated water budget. Because the CIG data are derived from PRISM data, this is not surprising; both datasets share the same probable underestimation. The origin of the error may be under-catch in the weather stations used to derive the PRISM dataset; Legates and Deliberty (1993) estimate precipitation undercatch due to wind at more than $18 \mathrm{~mm}$ per winter month in this region. Fog drip, or occult precipitation, also has been estimated at 30 percent of total precipitation in a Douglas-fir forest in the northern Oregon Cascades (Harr, 1982), and it likely is important in the Willapa calibration sub-watershed as well. Therefore, we were justified in manipulating the precipitation inputs. We did this by multiplying all daily precipitation totals by 1.1 for September-April, but because of greater flow underestimation in summer, we used 1.3 for May, June, and August, and 1.4 for July. Improved runoff ratios are shown in table 8. Final model performance and calibration scores are presented in the results section.

After adjusting the CIG data and calibrating the sub-watersheds, we created models of the ungaged study watersheds using the same parameter values as were used in their respective calibration sub-watersheds.

Table 7. Parameters used in model calibration. Some GIS-derived values were multipled by a coefficient during calibration; this is indicated by GIS Value * (some number).

\begin{tabular}{|c|c|c|c|c|c|c|c|c|}
\hline \multirow[b]{2}{*}{ Name } & \multirow[b]{2}{*}{ Description } & \multirow[b]{2}{*}{ Units } & \multirow{2}{*}{$\begin{array}{l}\text { Possible } \\
\text { range }\end{array}$} & \multirow[b]{2}{*}{ Default } & \multicolumn{4}{|c|}{ Calibrated value } \\
\hline & & & & & $\begin{array}{c}\text { Coos } \\
\text { Bay }\end{array}$ & $\begin{array}{l}\text { Coquille } \\
\text { River }\end{array}$ & $\begin{array}{l}\text { Willapa } \\
\text { Bay }\end{array}$ & $\begin{array}{c}\text { Yaquina } \\
\text { Bay }\end{array}$ \\
\hline carea_max & $\begin{array}{l}\text { Maximum possible area } \\
\text { contributing to surface } \\
\text { runoff expressed as a } \\
\text { portion of the HRU area }\end{array}$ & $\begin{array}{l}\text { Decimal } \\
\text { fraction }\end{array}$ & 0 to 1 & 0.6 & 0.6 & 0.6 & 0.3 & 0.3 \\
\hline crad_coef & $\begin{array}{l}\text { Coefficient (B) in } \\
\text { Thompson (1976) equation }\end{array}$ & None & 0.1 to 0.7 & 0.4 & 0.7 & 0.7 & 0.7 & 0.7 \\
\hline
\end{tabular}




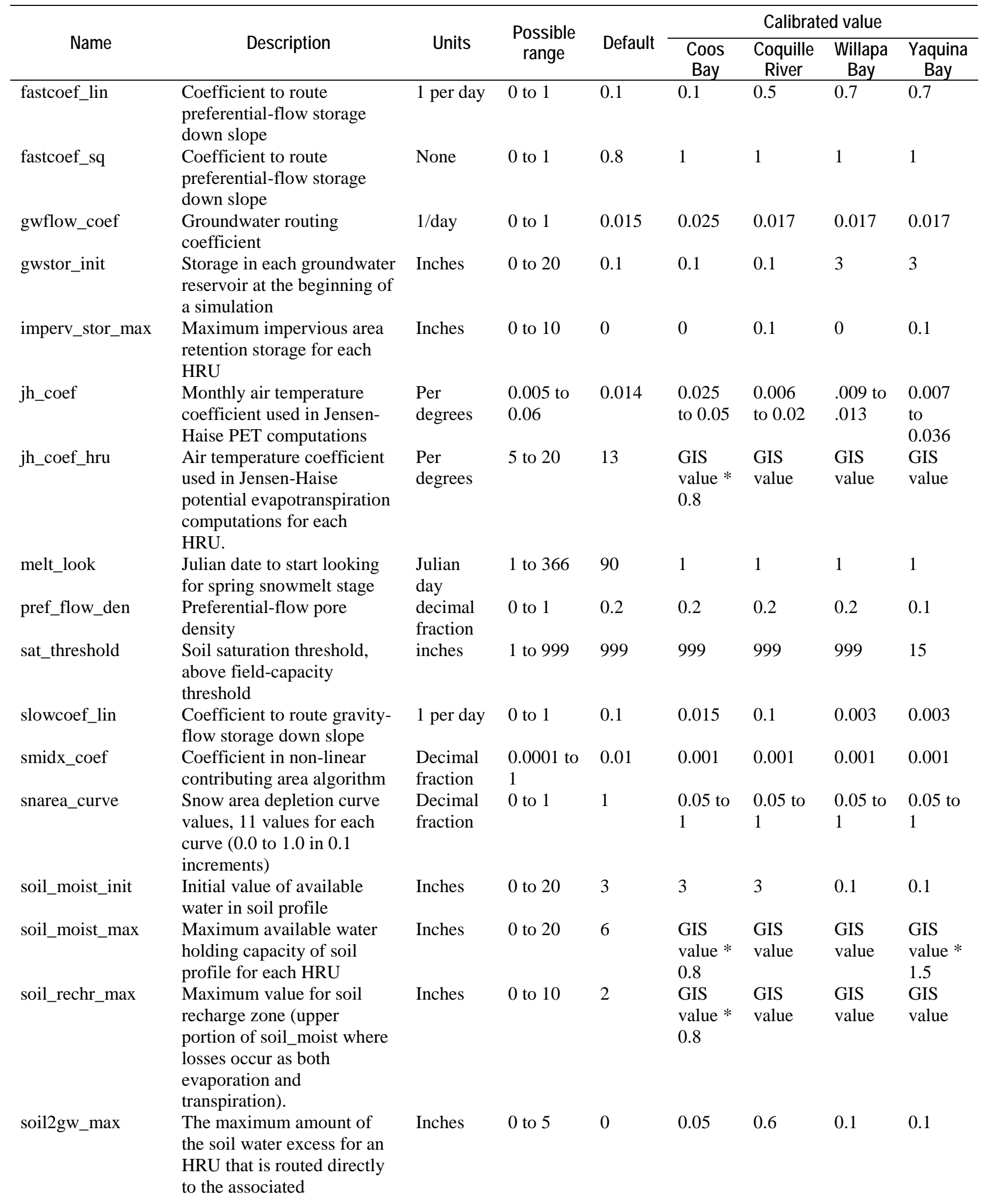




\begin{tabular}{|c|c|c|c|c|c|c|c|c|}
\hline \multirow[b]{2}{*}{ Name } & \multirow[b]{2}{*}{ Description } & \multirow[b]{2}{*}{ Units } & \multirow{2}{*}{$\begin{array}{l}\text { Possible } \\
\text { range }\end{array}$} & \multirow[b]{2}{*}{ Default } & \multicolumn{4}{|c|}{ Calibrated value } \\
\hline & & & & & $\begin{array}{c}\text { Coos } \\
\text { Bay }\end{array}$ & $\begin{array}{l}\text { Coquille } \\
\text { River }\end{array}$ & $\begin{array}{l}\text { Willapa } \\
\text { Bay }\end{array}$ & $\begin{array}{l}\text { Yaquina } \\
\text { Bay }\end{array}$ \\
\hline & $\begin{array}{l}\text { groundwater reservoir each } \\
\text { day }\end{array}$ & & & & & & & \\
\hline ssr2gw_exp & $\begin{array}{l}\text { Coefficient in equation used } \\
\text { to route water from the } \\
\text { subsurface reservoirs to the } \\
\text { groundwater reservoirs }\end{array}$ & None & 0 to 3 & 1 & 1 & 0.5 & 0.5 & 0.5 \\
\hline ssr2gw_rate & $\begin{array}{l}\text { Coefficient in equation used } \\
\text { to route water from the } \\
\text { subsurface reservoirs to the } \\
\text { groundwater reservoirs }\end{array}$ & 1 per day & 0 to 1 & 0.1 & 0.15 & 0.001 & 0.001 & 0.001 \\
\hline tmax_allrain & $\begin{array}{l}\text { If maximum temperature of } \\
\text { an HRU is greater than or } \\
\text { equal to this value (for each } \\
\text { month, January to } \\
\text { December), precipitation is } \\
\text { assumed to be rain, in deg C } \\
\text { or F, depending on units of } \\
\text { data }\end{array}$ & Degrees & 0 to 90 & 40 & $\begin{array}{l}41 \text { to } \\
74\end{array}$ & $\begin{array}{l}41 \text { to } \\
74\end{array}$ & $\begin{array}{l}41 \text { to } \\
74\end{array}$ & $\begin{array}{l}41 \text { to } \\
74\end{array}$ \\
\hline tmax_lapse & $\begin{array}{l}\text { Change in min. temp. per } \\
1000 \text { elev_units of elevation } \\
\text { change for each month }\end{array}$ & Degrees & -10 to 10 & 3 & $\begin{array}{l}-2.0 \text { to } \\
-0.6\end{array}$ & $\begin{array}{l}-9.2 \text { to } \\
10\end{array}$ & $\begin{array}{l}-2.0 \text { to } \\
-0.6\end{array}$ & $\begin{array}{l}-4.0 \text { to } \\
-1.3\end{array}$ \\
\hline tmin_lapse & $\begin{array}{l}\text { Change in min. temp. per } \\
1000 \text { elev_units of elevation } \\
\text { change for each month }\end{array}$ & Degrees & -10 to 10 & 3 & $\begin{array}{l}-1.3 \text { to } \\
-0.2\end{array}$ & $\begin{array}{l}-4.7 \text { to } \\
0\end{array}$ & $\begin{array}{l}-1.3 \text { to } \\
-0.2\end{array}$ & $\begin{array}{l}-2.57 \text { to } \\
-0.47\end{array}$ \\
\hline transp_beg & $\begin{array}{l}\text { Month to begin summing } \\
\text { tmaxf for each HRU; when } \\
\text { sum is >= to transp_tmax, } \\
\text { transpiration begins }\end{array}$ & Month & 1 to 12 & 4 & 4 & 4 & 1 & 1 \\
\hline transp_end & $\begin{array}{l}\text { Month to stop transpiration } \\
\text { computations; transpiration } \\
\text { is computed thru end of } \\
\text { previous month }\end{array}$ & Month & 1 to 12 & 10 & 10 & 10 & 12 & 12 \\
\hline
\end{tabular}

Table 8. Runoff ratios in all calibration watersheds, and new runoff ratios in the Willapa calibration watershed after Climate Impacts Group adjustments.

[Q $\mathrm{Q}_{\text {meas }}$ - measured flow; $\mathrm{Q}_{\text {sim- }}$ simulated flow; $\mathrm{P}_{\mathrm{CIG}}$ - CIG precipitation]

\begin{tabular}{|c|c|c|c|c|c|}
\hline $\begin{array}{l}\text { Calibration sub- } \\
\text { watershed }\end{array}$ & $\mathrm{Q}_{\text {meas }} / \mathrm{P}_{\mathrm{CIG}}$ & $\begin{array}{c}Q_{\text {meas }} / P_{\text {CIG }} \text { after CIG } \\
\text { adjustments }\end{array}$ & $\mathrm{Q}_{\text {sim }} / \mathrm{P}_{\mathrm{cIG}}$ & $\begin{array}{l}Q_{\text {sim }} / P_{\text {cIG }} \text { after CIG } \\
\text { adjustments }\end{array}$ & Reference period \\
\hline Coos & 0.47 & N/A & 0.43 & N/A & 1982-1996 \\
\hline Coquille & 0.69 & N/A & 0.68 & N/A & 1970-1996 \\
\hline Willapa & 0.90 & 0.80 & 0.74 & 0.78 & 1970-2000 \\
\hline Yaquina & 0.62 & N/A & 0.62 & N/A & 1972-1991 \\
\hline
\end{tabular}




\section{Use of Climate Scenarios}

As described in "Data", we obtained four NARCCAP simulations with complete daily records for a reference period (1971-1995) and a future period (2041-2065) (table 4). We used these data to force the calibrated models of the watersheds of interest (not the calibration sub-watersheds), and then compared reference and future outputs within models to calculate potential climate-induced runoff changes. Although we adjusted the precipitation inputs used to calibrate for Willapa Bay, we did not make any changes to the NARCCAP precipitation data because these different climate models would not necessarily share the same biases. The final outputs are summarized in "Results".

\section{Uncertainty Analysis}

All physical modeling of future conditions involves uncertainty. In hydrologic modeling, the primary sources of uncertainty are future climate and emissions scenarios. Precipitation is especially uncertain, and becomes more uncertain under high carbon emissions scenarios. Hydrological model parameter values also contribute to uncertainty (Praskievicz and Chang, 2009). Because PRMS uses many parameters, there is a strong likelihood of equifinality (Beven and Freer, 2001; Kirchner, 2006; Beven and others, 2007), which means that many different combinations of parameter values would all give rise to a statistically acceptable outcome. That is, one set of parameter values can score as well as another, even if it poorly reflects the physical reality. This results in uncertainty in the accuracy of future projections. Future climate models also introduce uncertainty to the simulations, especially in their precipitation estimates (fig. 6). To estimate the degree of uncertainty owing to PRMS and climate models, we conducted an uncertainty analysis.

After Chang and Jung (2010), we used a modified version of a method first suggested by Wilby (2005) to estimate the amount of uncertainty associated with each source. We selected 13 sensitive calibration parameters (table 9) and generated random values within the acceptable range for each parameter. A total of 20,000 random sets of parameters were generated for each calibration subwatershed using Latin hypercube sampling in Matrix Laboratory (MATLAB ${ }^{\circledR}$ ) (MathWorks, Natick, Massachusetts). Wilby (2005) used Monte Carlo sampling to generate his parameter sets, but we used Latin hypercube sampling instead because it has been shown to be more effective and efficient than Monte Carlo sampling (Davey, 2008). Each parameter set then was used in PRMS to simulate runoff, and the performance of each set was evaluated.

We then selected parameter sets that performed well for each calibration sub-watershed. Our criteria were: a Nash Sutcliffe Efficiency (NSE) coefficient of 0.8 or more, an index of agreement of greater than or equal to 0.85 , and an annual percent bias of no more than plus-or-minus 10 percent. All performance scores were calculated using daily data. The NSE is a commonly used measure of goodness of fit in hydrologic models; as a model improves, its NSE approaches 1 (Nash and Sutcliffe, 1970). We changed the criteria slightly for the Coos Bay calibration sub-watershed because none of its 20,000 randomly generated parameter sets had an NSE of 0.8 or more. We lowered the cutoff for this sub-watershed to an NSE of 0.7 , but kept the other criteria the same. After identifying the best parameter sets for each calibration sub-watershed, we used them to find the uncertainty associated with PRMS parameters.

To estimate uncertainty owing to climate models, we translated the best selected parameter sets to the ungaged study watersheds, and then forced these models with the four climate scenarios (table 4). We used these outputs to find uncertainty in estimated changes in monthly flow, coefficient of variation (CV), top 5 percent of flow, and 7-day low flow from the reference period to the future period. The CV is the ratio of the standard deviation to the mean, and frequently is used as a metric of variability in flow. The top 5 percent, or Q5, is the mean discharge rate of the 5 percent of days with the highest flow 
for each year. Seven-day low flow is the lowest 7-day running mean flow for each year (Chang and Jung, 2010). This metric is similar to 7Q10, a standard hydrologic metric, but is averaged over 30 years instead of 10 years. All findings are presented in "Results". Because all four climate scenarios use one emission scenario (as discussed in "Data"), uncertainty in climate projections is greater than the results indicate.

Table 9. Precipitation Runoff Modeling System parameters used in uncertainty analysis.

\begin{tabular}{|c|c|c|}
\hline Name & Description & Possible range \\
\hline carea_max & $\begin{array}{l}\text { Maximum possible area contributing to surface runoff expressed as a portion } \\
\text { of the HRU area }\end{array}$ & 0 to 1 \\
\hline crad_coef & Coefficient (B) in Thompson (1976) equation & 0.1 to 0.7 \\
\hline fastcoef_lin & Coefficient to route preferential-flow storage down slope & 0 to 1 \\
\hline fastcoef_sq & Coefficient to route preferential-flow storage down slope & 0 to 1 \\
\hline gwflow_coef & Groundwater routing coefficient & 0 to 1 \\
\hline pref_flow_den & Preferential-flow pore density & 0 to 1 \\
\hline slowcoef_lin & Coefficient to route gravity-flow storage down slope & 0 to 1 \\
\hline slowcoef_sq & Coefficient to route gravity-flow storage down slope & 0 to 1 \\
\hline smidx_coef & Coefficient in non-linear contributing area algorithm & 0.0001 to 1 \\
\hline smidx_exp & Coefficient in non-linear contributing area algorithm & 0.2 to 0.8 \\
\hline soil2gw_max & $\begin{array}{l}\text { The maximum amount of the soil water excess for an HRU that is routed } \\
\text { directly to the associated groundwater reservoir each day }\end{array}$ & 0 to 5 \\
\hline ssr2gw_exp & $\begin{array}{l}\text { Coefficient in equation used to route water from the subsurface reservoirs to } \\
\text { the groundwater reservoirs }\end{array}$ & 0 to 3 \\
\hline ssr2gw_rate & $\begin{array}{l}\text { Coefficient in equation used to route water from the subsurface reservoirs to } \\
\text { the groundwater reservoirs }\end{array}$ & 0 to 1 \\
\hline
\end{tabular}

\section{Results}

\section{Model Performance}

Four modeled goodness-of fit metrics: NSE, correlation coefficient, index of agreement, and annual percent bias are shown in table 10. All scores are based on daily data. Mean simulated and measured monthly flow rates are shown in figure 16, and a monthly hydrograph for each sub-watershed for October 1982-September 1991 is shown in figures 17-20.

Together, the figures and table show that the calibration sub-watersheds performed well. For example, annual percent bias was less than plus-or-minus 5 percent in all cases, and the NSE was 0.8 or greater for all watersheds except for the Coos Bay South Slough calibration sub-watershed. The Coos Bay South Slough calibration sub-watershed performed more poorly than the other watersheds by all measures, which is not surprising, given its short period of record, geologic composition, small area, and the likely influence of tides close to the ocean. Peak flows were underestimated in this subwatershed (fig. 17), in the Willapa Bay sub-watershed (fig. 19), and, to a lesser extent, in the Yaquina 
Bay sub-watershed (fig. 20). This systematic underestimation bias in peak flows could be due to an underlying weakness in the PRMS model, precipitation under-catch, or some combination thereof. Overall, however, performance was satisfactory, because the NSE scores were above the 0.6 cutoff suggested in Choi and Beven (2007).
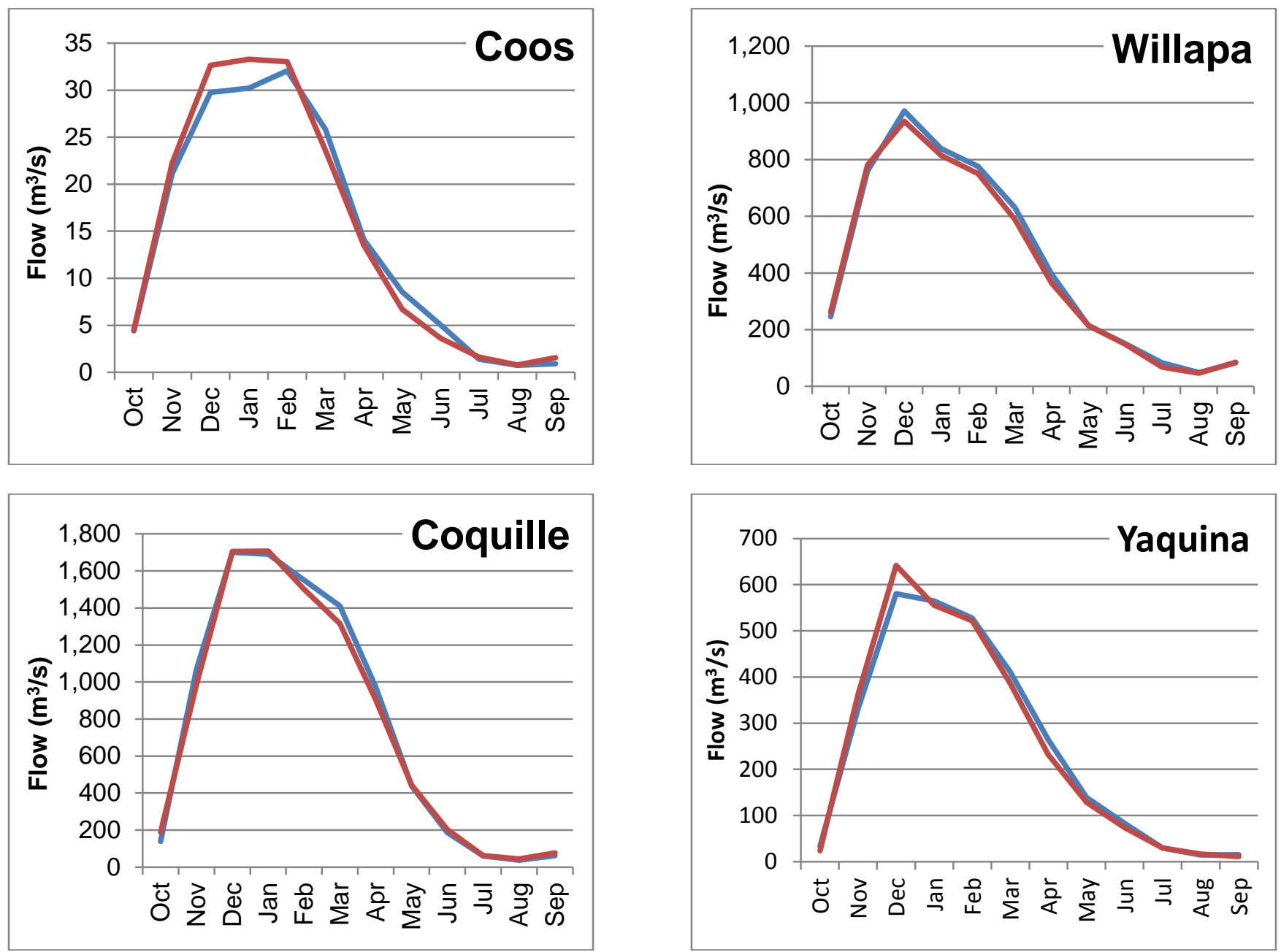

\section{Measured \\ Simulated}

Figure 16. Mean monthly performance of calibrated models. 


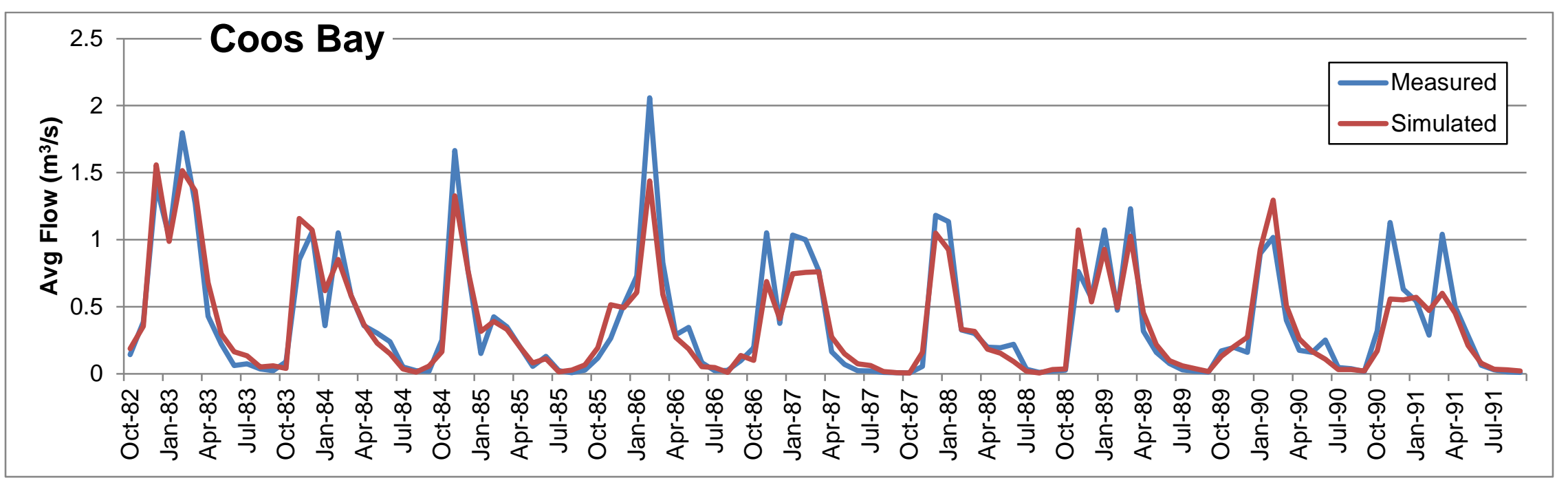

Figure 17. Monthly hydrograph of Coos Bay calibration sub-watershed, Oregon, October 1982-September 1991.

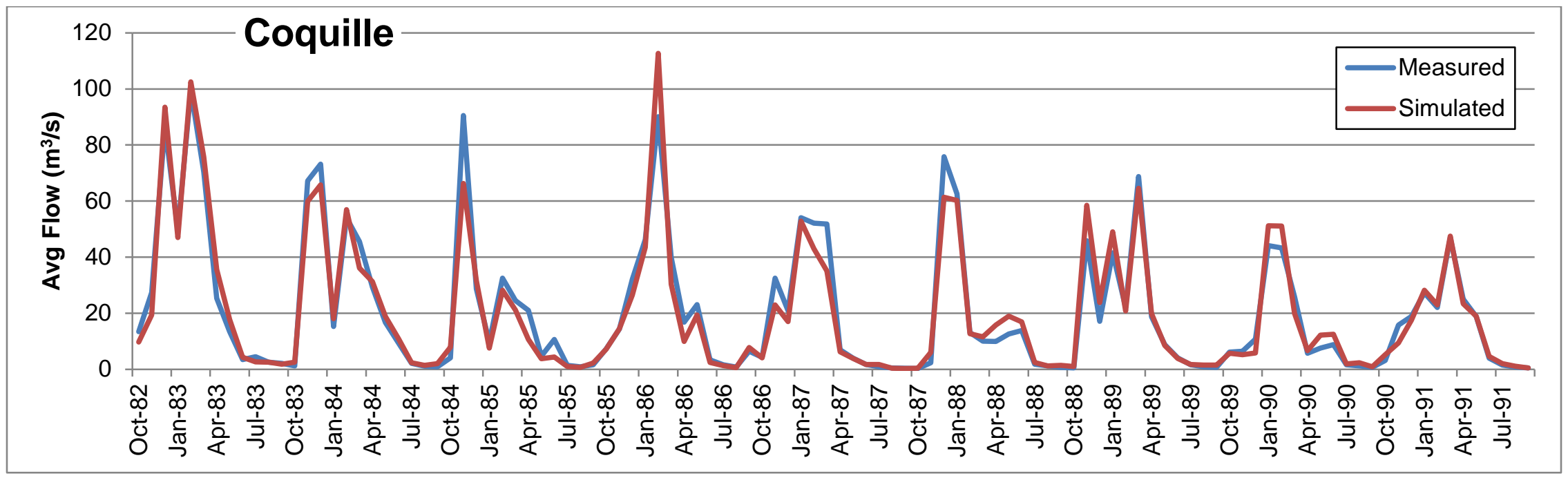

Figure 18. Monthly hydrograph of Coquille River calibration sub-watershed, Oregon, October 1982-September 1991. 


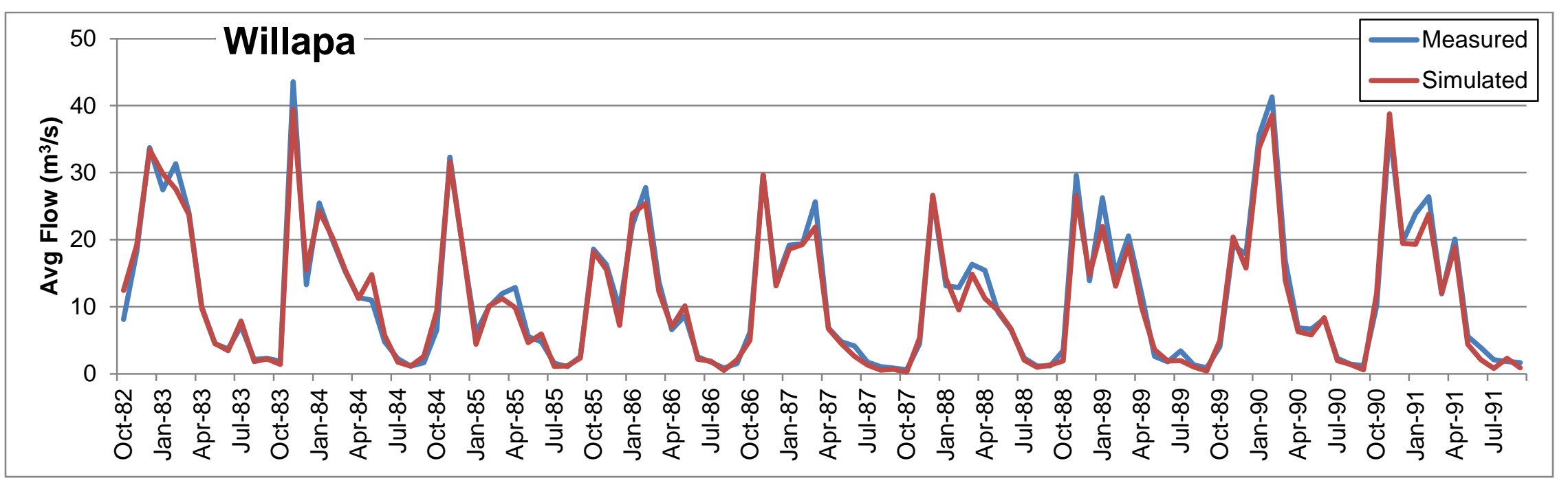

Figure 19. Monthly hydrograph of Willapa Bay calibration sub-watershed, Washington, October 1982- September 1991.

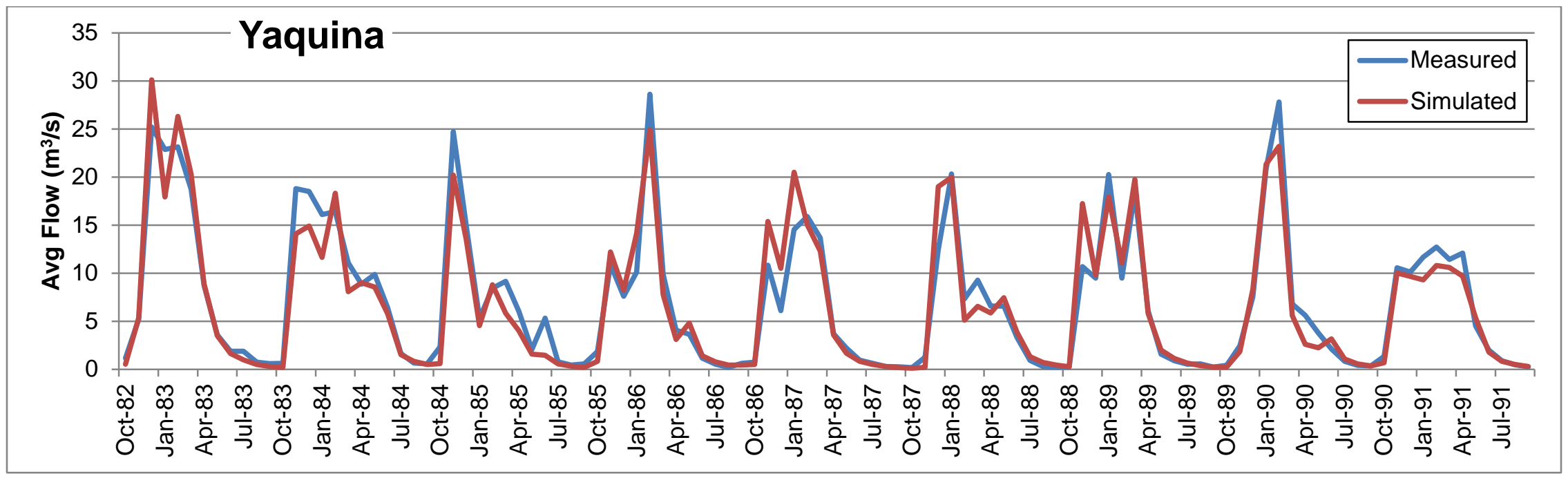

Figure 20. Monthly hydrograph of Yaquina Bay calibration sub-watershed, Oregon, October 1982-September 1991. 
Table 10. Model goodness of fit metrics.

\begin{tabular}{|c|c|c|c|c|}
\hline $\begin{array}{c}\text { Calibration } \\
\text { Sub-watershed }\end{array}$ & $\begin{array}{l}\text { Nash-Sutcliffe } \\
\text { Efficiency } \\
\text { (NSE) }\end{array}$ & $\begin{array}{c}\text { Correlation } \\
\text { coefficient } \\
\text { (r) }\end{array}$ & $\begin{array}{c}\text { Index of } \\
\text { agreement } \\
\text { (d) }\end{array}$ & $\begin{array}{c}\text { Annual bias } \\
\text { (percent) }\end{array}$ \\
\hline \multicolumn{5}{|l|}{ Coos Bay } \\
\hline $\begin{array}{c}\text { Calibration period } \\
\text { (1982-1991) }\end{array}$ & 0.73 & 0.85 & 0.91 & 4.92 \\
\hline $\begin{array}{c}\text { Verification Period } \\
\quad(1991-1996)\end{array}$ & 0.69 & 0.84 & 0.91 & -3.43 \\
\hline $\begin{array}{l}\text { Total period } \\
(1982-1996)\end{array}$ & 0.71 & 0.85 & 0.91 & 1.73 \\
\hline \multicolumn{5}{|l|}{ Coquille River } \\
\hline $\begin{array}{c}\text { Calibration period } \\
\qquad(1970-1984)\end{array}$ & 0.87 & 0.93 & 0.96 & -3.38 \\
\hline $\begin{array}{c}\text { Verification period } \\
(1984-1996)\end{array}$ & 0.81 & 0.91 & 0.95 & $0.52 \%$ \\
\hline $\begin{array}{l}\text { Total Period } \\
(1970-1996)\end{array}$ & 0.84 & 0.92 & 0.96 & -1.90 \\
\hline \multicolumn{5}{|l|}{ Willapa Bay } \\
\hline $\begin{array}{c}\text { Calibration period } \\
(1970-1985) \\
\end{array}$ & 0.88 & 0.94 & 0.97 & -1.10 \\
\hline $\begin{array}{c}\text { Verificationperiod } \\
(1985-2000)\end{array}$ & 0.90 & 0.95 & 0.97 & -4.30 \\
\hline $\begin{array}{l}\text { Total period } \\
(1970-2000)\end{array}$ & 0.89 & 0.94 & 0.97 & -2.69 \\
\hline
\end{tabular}

Yaquina Bay

\begin{tabular}{|c|}
\hline $\begin{array}{c}\text { Calibration period } \\
(1972-1982)\end{array}$ \\
\hline Verification period \\
$(1982-1991)$ \\
\hline Total period \\
$(1972-1991)$ \\
\hline
\end{tabular}

$\begin{array}{llll}0.87 & 0.94 & 0.97 & 2.55 \\ 0.83 & 0.92 & 0.96 & -3.53 \\ 0.85 & 0.93 & 0.96 & -0.37\end{array}$

Correlation coefficient $(r)=S S_{o s} / \sqrt{S S_{o} \times S S_{s}}, S S_{o s}=\sum\left(O_{i}-\bar{O}\right)\left(S_{i}-\bar{S}\right), S S_{o}=\sum\left(O_{i}-\bar{O}^{2}, S S_{s}=\sum\left(S_{i}-\bar{S}\right)^{2}\right.$ where $O$ is observed flow and $S$ is simulated flow. Nash-Sutcliffe efficiency (NSE) $=\left[\sum\left(O_{i}-\bar{O}\right)^{2}-\sum\left(O_{i}-S_{i}\right)^{2}\right] / \sum\left(O_{i}-\bar{O}\right)^{2}$, where $\bar{O}$ is mean observed flow.

Index of agreement $(d)=1-\left[\sum\left(S_{i}-O_{i}\right)^{2} /\left(\sum\left(\left|S_{i}-\bar{O}\right|+\left|O_{i}-O\right|\right)^{2}\right)\right]$.

\section{PRMS Outputs with Climate Scenarios}

\section{Percent Change in Monthly Mean Flow Rate from Reference Period to Future Period}

The outputs produced by forcing the ungaged study watershed models with NARCCAP scenarios are summarized in figures 21-30. Figures 21-24 show the percent change in mean 
monthly flow from the reference period to the future period. Each watershed has its own chart, and the different NARCCAP scenarios are symbolized by contrasting colors. The inconsistency in the direction of change among the scenarios is striking. In most months, CRCM-CGCM3 and RCM3-CGCM3 (which share an AOGCM; see table 4) show increasing trends, whereas the other two scenarios show decreasing trends throughout much of the year. Only in October and November is there more agreement among the models; in these months, almost all models show increasing mean flow. This is clear in figure 25, which shows the inter-watershed mean percent change for each month. However, the September values for the Coquille River watershed do not agree with the general pattern (fig. 22). This may be because the Coquille River watershed is the southernmost in this study, and is likely to have differing future precipitation and temperature. In figure 26, the ensemble mean of the four climate scenarios is displayed, and the different colored bars represent watersheds rather than scenarios. Here, the mean increases in October and November flow are even more apparent. Decreases in summer flow (July and August especially) also become evident in figure 26, because although the direction of the trend varies among the scenarios for most watersheds in this period, the magnitude of the decreasing trends is much greater, and so the ensemble mean shows a decrease.

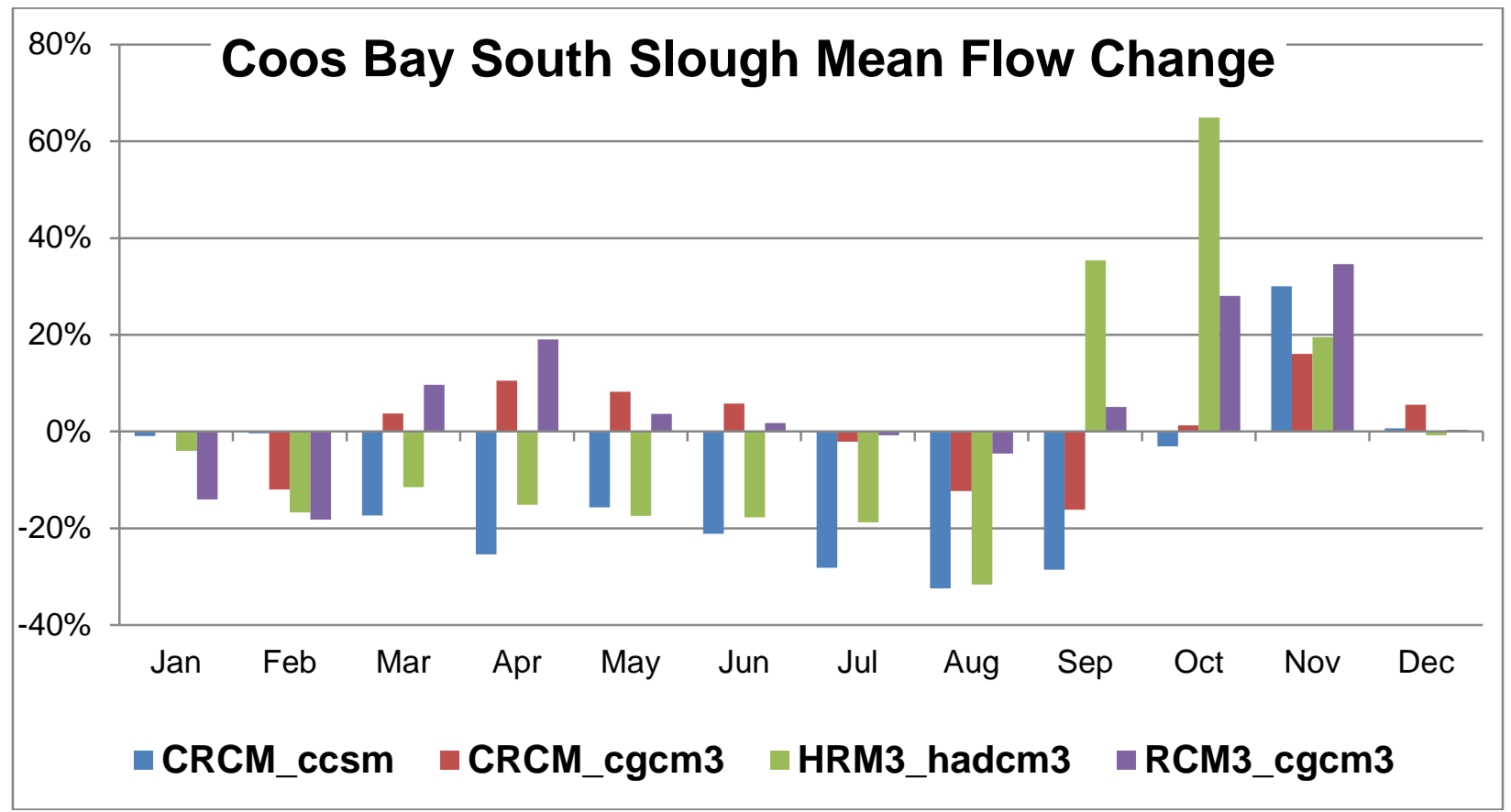

Figure 21. Percent change in mean monthly percent flow from reference period (1971-1995) to future period (2041-2065), Coos Bay South Slough watershed, Oregon. 


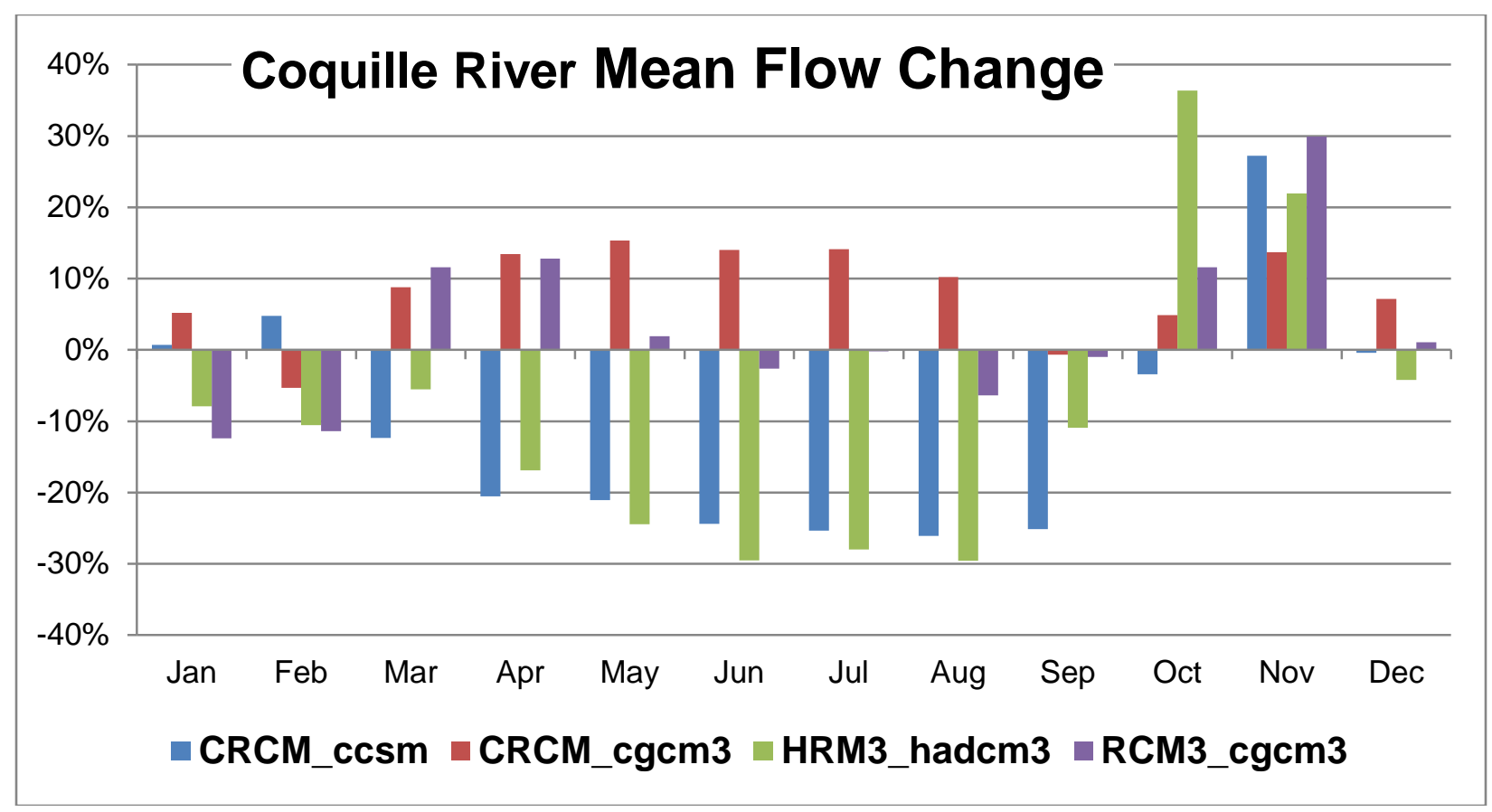

Figure 22. Percent change in mean monthly percent flow from reference period (1971-1995) to future period (2041-2065), Coquille River watershed, Oregon.

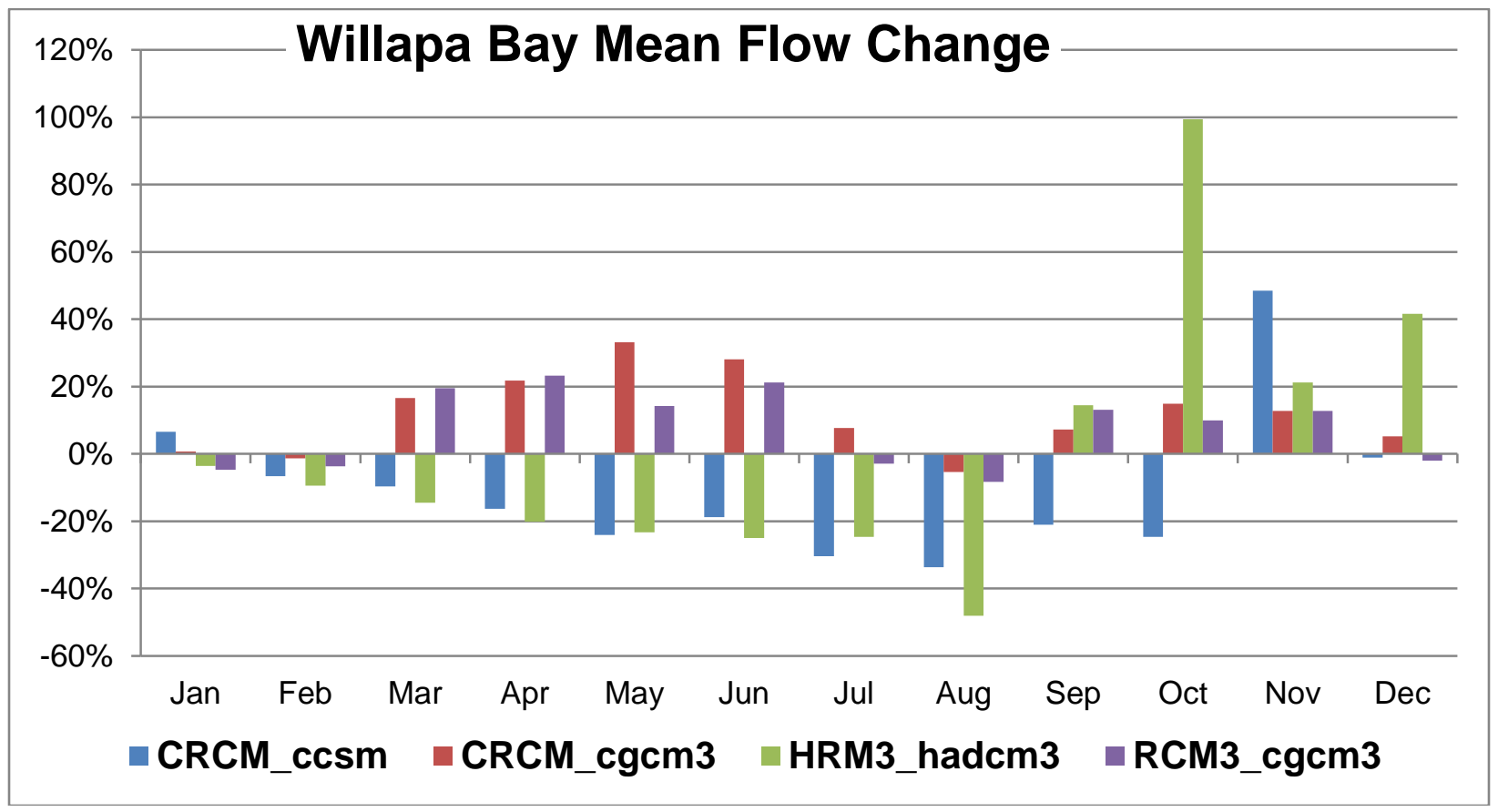

Figure 23. Percent change in mean monthly percent flow from reference period (1971-1995) to future period (2041-2065), Willapa Bay watershed, Washington. 


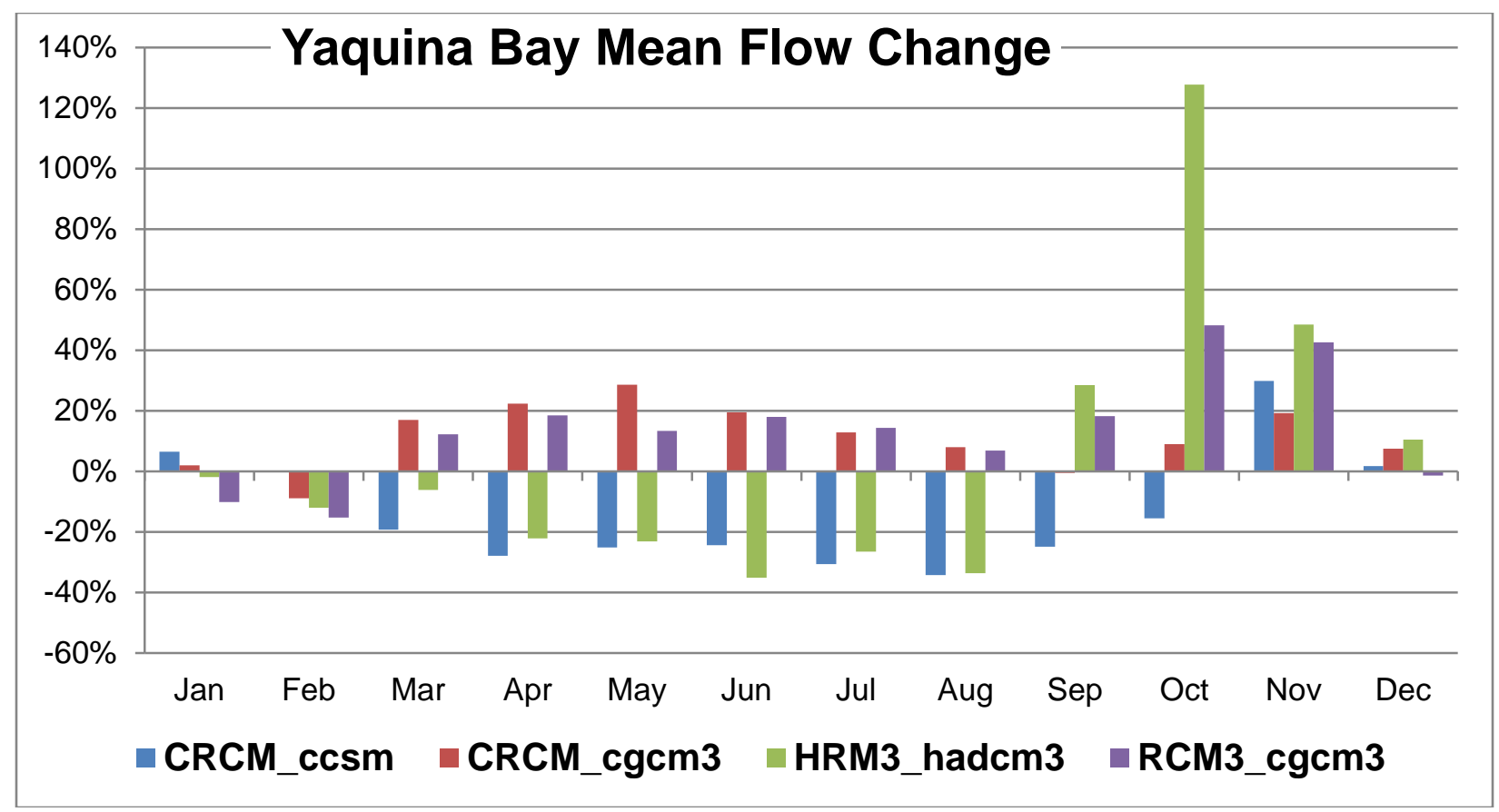

Figure 24. Percent change in mean monthly percent flow from reference period (1971-1995) to future period (2041-2065), Yaquina Bay watershed, Oregon.

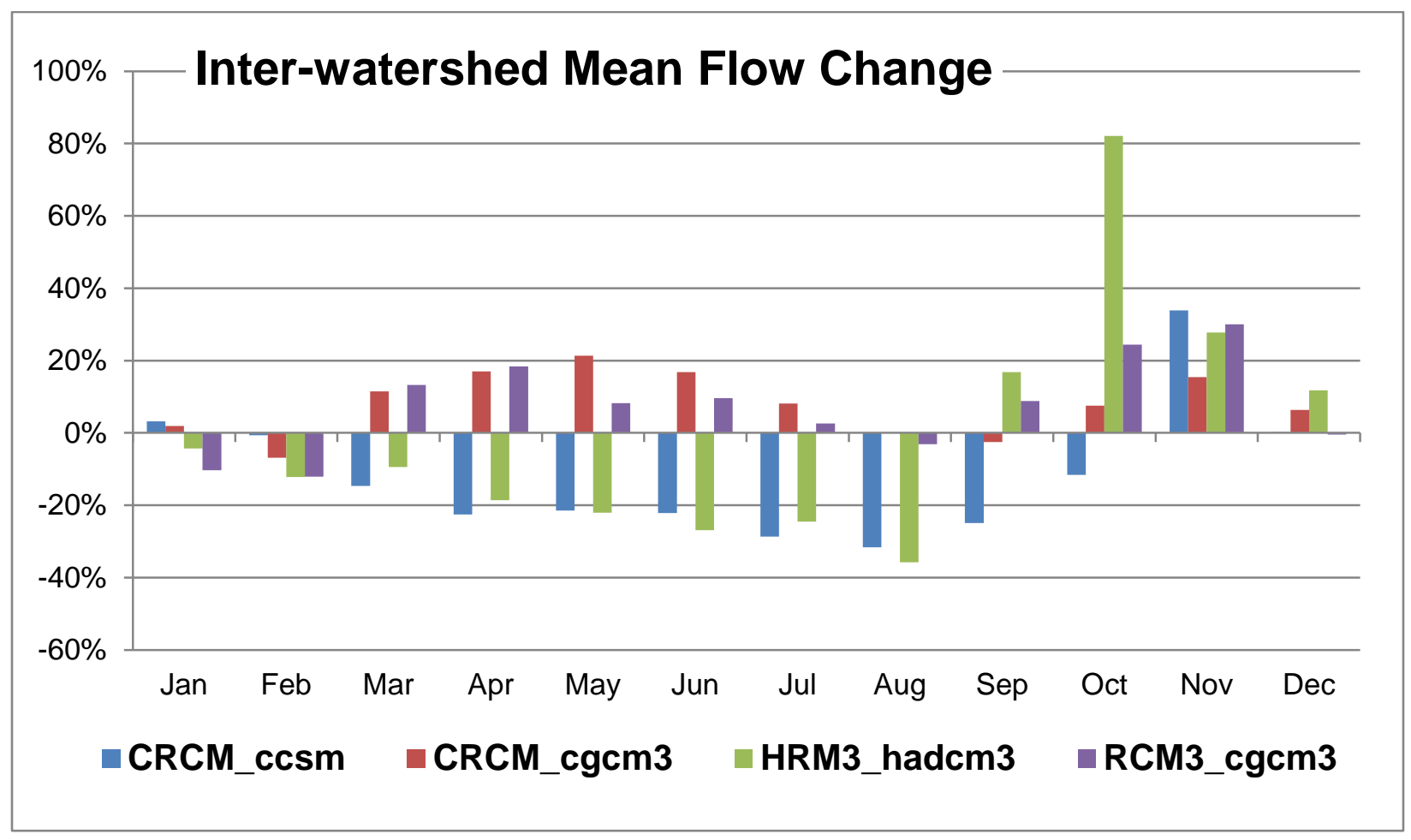

Figure 25. Percent change in mean monthly percent flow from reference period (1971-1995) to future period (2041-2065), averaged across all four study-area watersheds. 


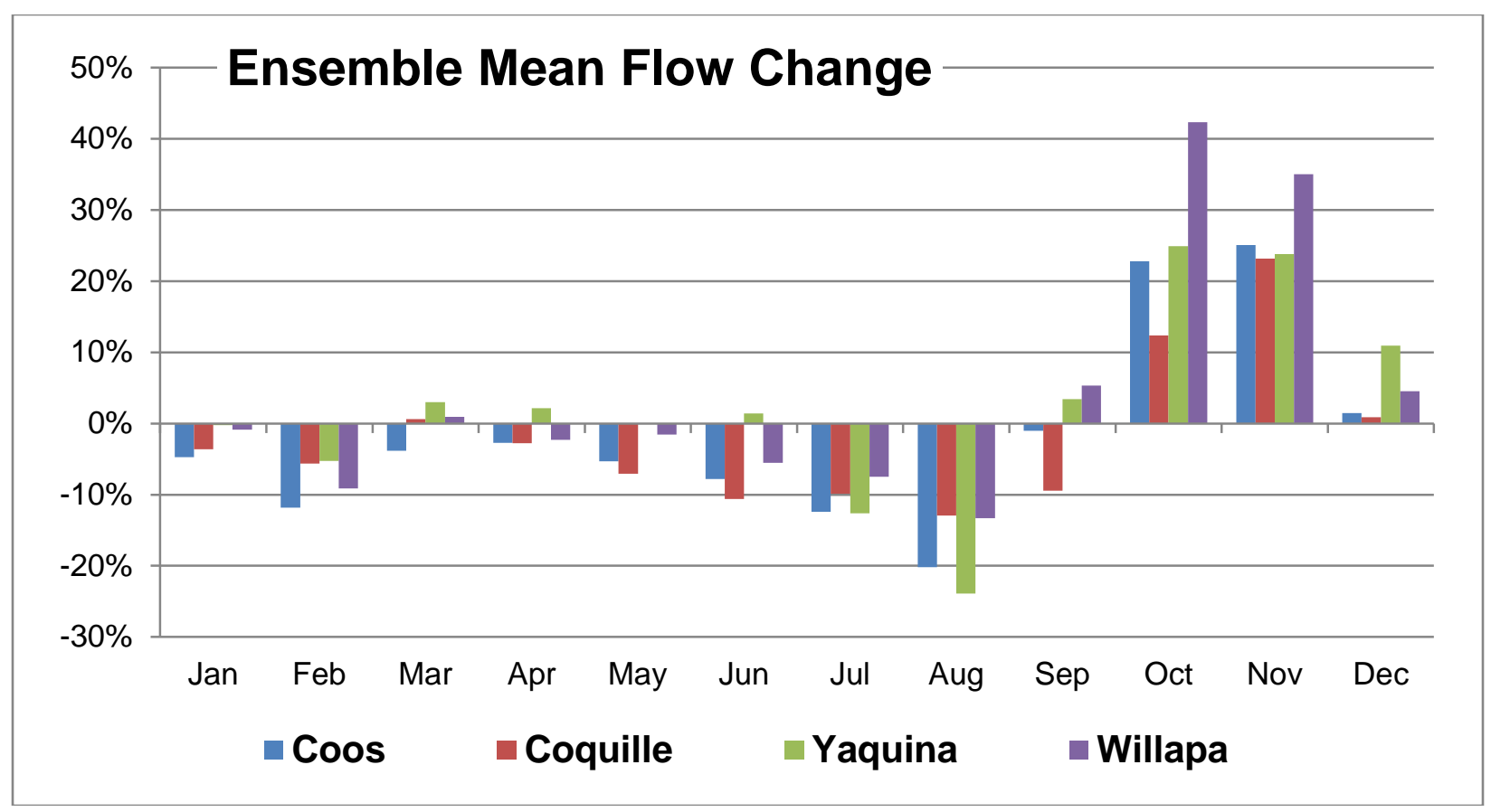

Figure 26. Climate scenario ensemble mean change in mean monthly percent flow from reference point (1971-1995) to future period (2041-2065), by study-area watershed.

Changes in Monthly Coefficient of Variation (CV) from Reference to Future Period

As shown in figures 27 and 28, CV shows a small increase in most months (SeptemberMay) and for most scenarios. In July and August, however, CV decreases, probably because of fewer precipitation events and, thus, lower and steadier flow rates. The most dramatic change, however, is a spike in September CV in the HRM3-HADCM3 and RCM3-CGCM3 scenarios (fig. 27). Even when all scenarios are averaged (fig. 28), this increase is the most notable result. The increase could be owing to the fact that more rainstorms and associated variability in flow will be more likely in September with climate change.

\section{Changes in Other Indices from Reference Period to Future Period}

We also investigated percent change in the top 5 percent of flow (fig. 29) and in the 7-day low flow (fig. 30). The Willapa Bay and Yaquina Bay watersheds show likely increases in top 5 percent of flow because all four models agree as to sign, and three of four scenarios show increases of more than 5 percent from the reference period to the future period. The percent change in 7-day low flow shows less agreement among climate scenarios, although there is an ensemble mean decrease for all watersheds except the Yaquina Bay watershed. The differing value in the Yaquina Bay watershed may arise from local variability in the RCMs. In an investigation of GCM downscaling techniques for hydrologic modeling, Wood and others (2004) determined that data downscaled with an RCM gave hydrologically probable results only after bias correction. Poor resolution of realism of the RCMs also may be a factor here. Given the higher degree of uncertainty associated with these low flows, and the lack of a strong signal, it is better not to rely on the ensemble mean in this case. 


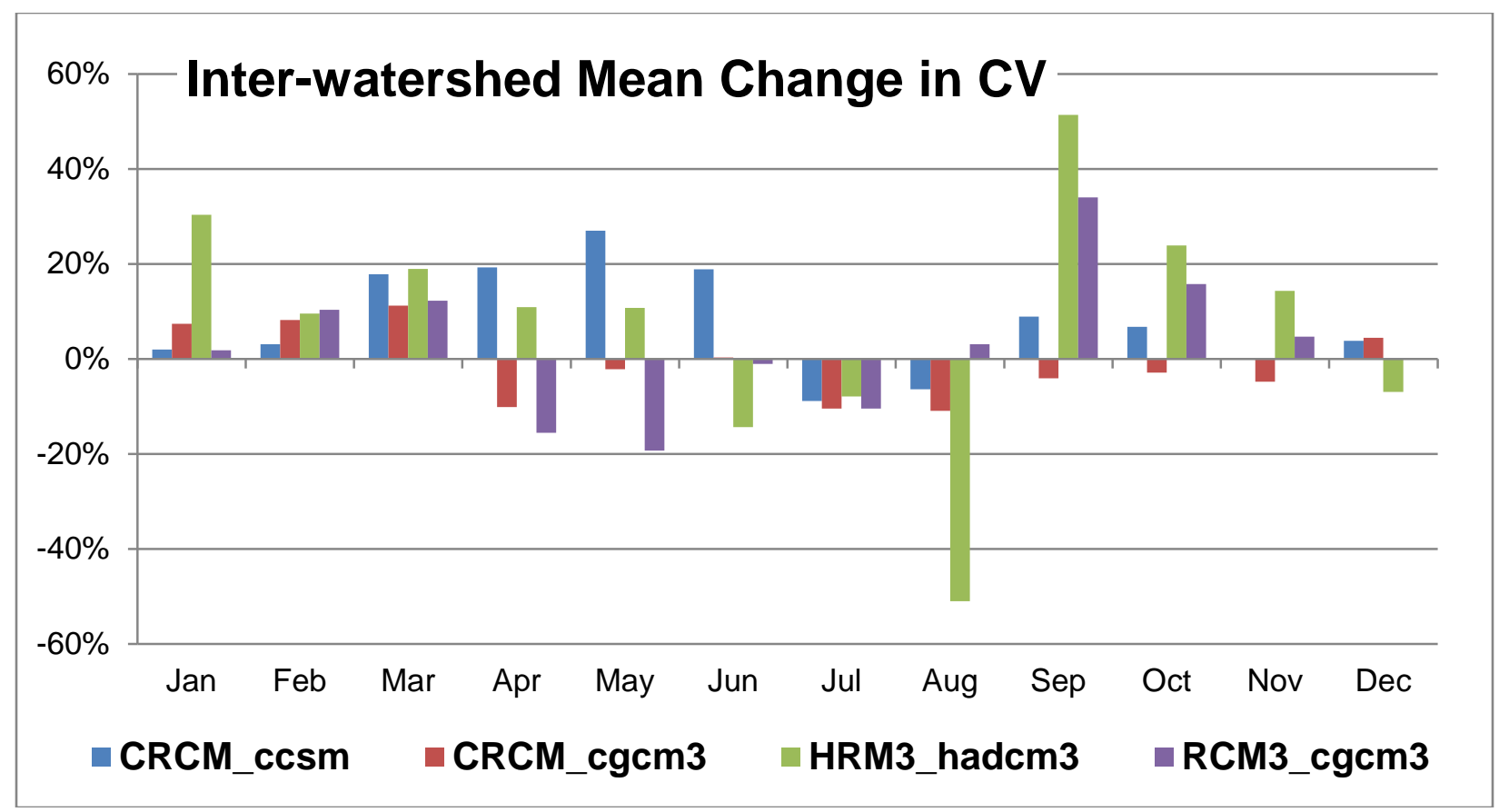

Figure 27. Graph showing percent change in monthly coefficient of variation (CV) from reference period (1971-1995) to future period (2041-2065), averaged across all four study-area watersheds.

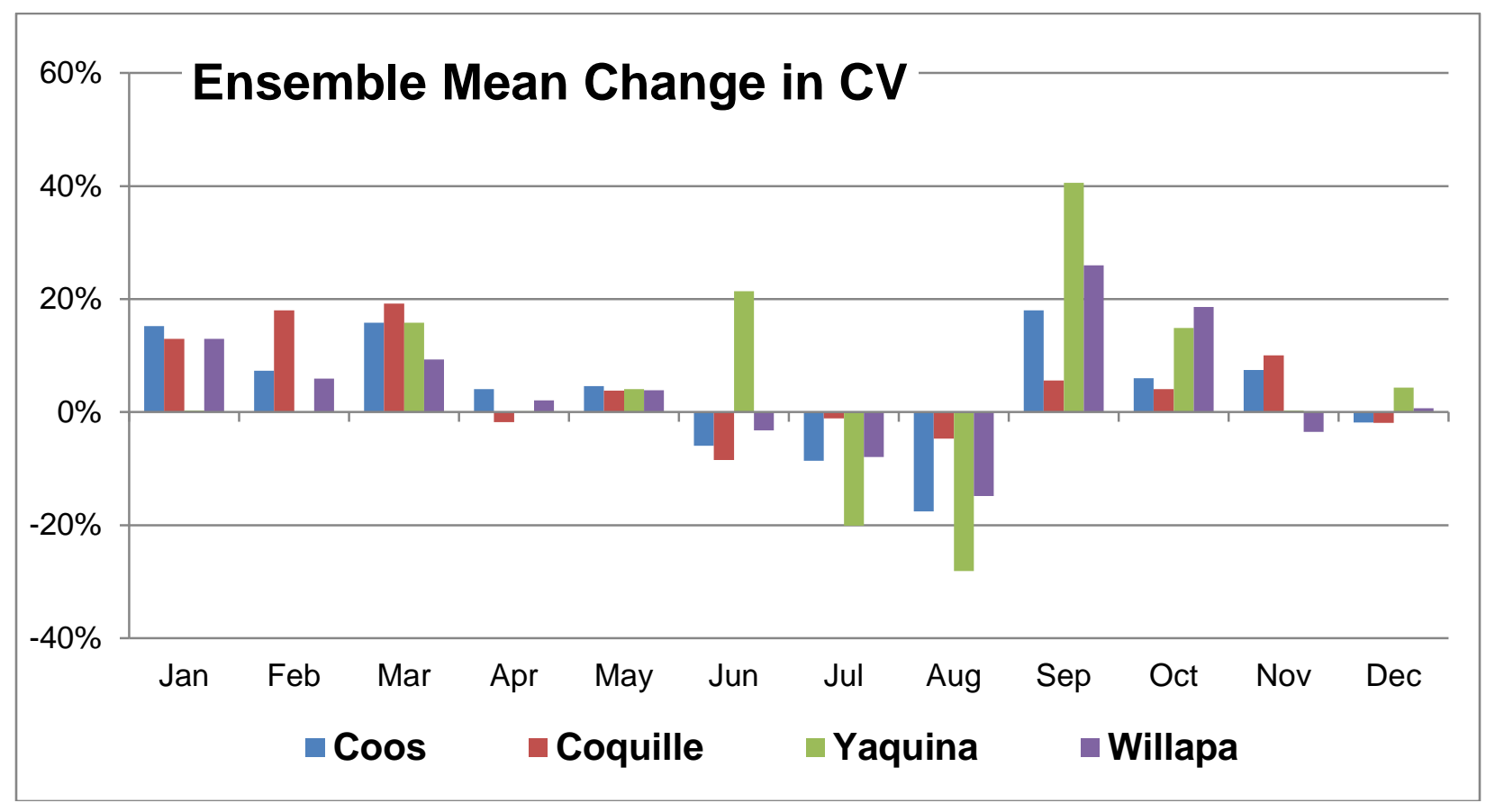

Figure 28. Graph showing climate scenario ensemble mean change in monthly coefficient of variation (CV) from reference period (1971-1995) to future period (2041-2065), by study-area watershed. 


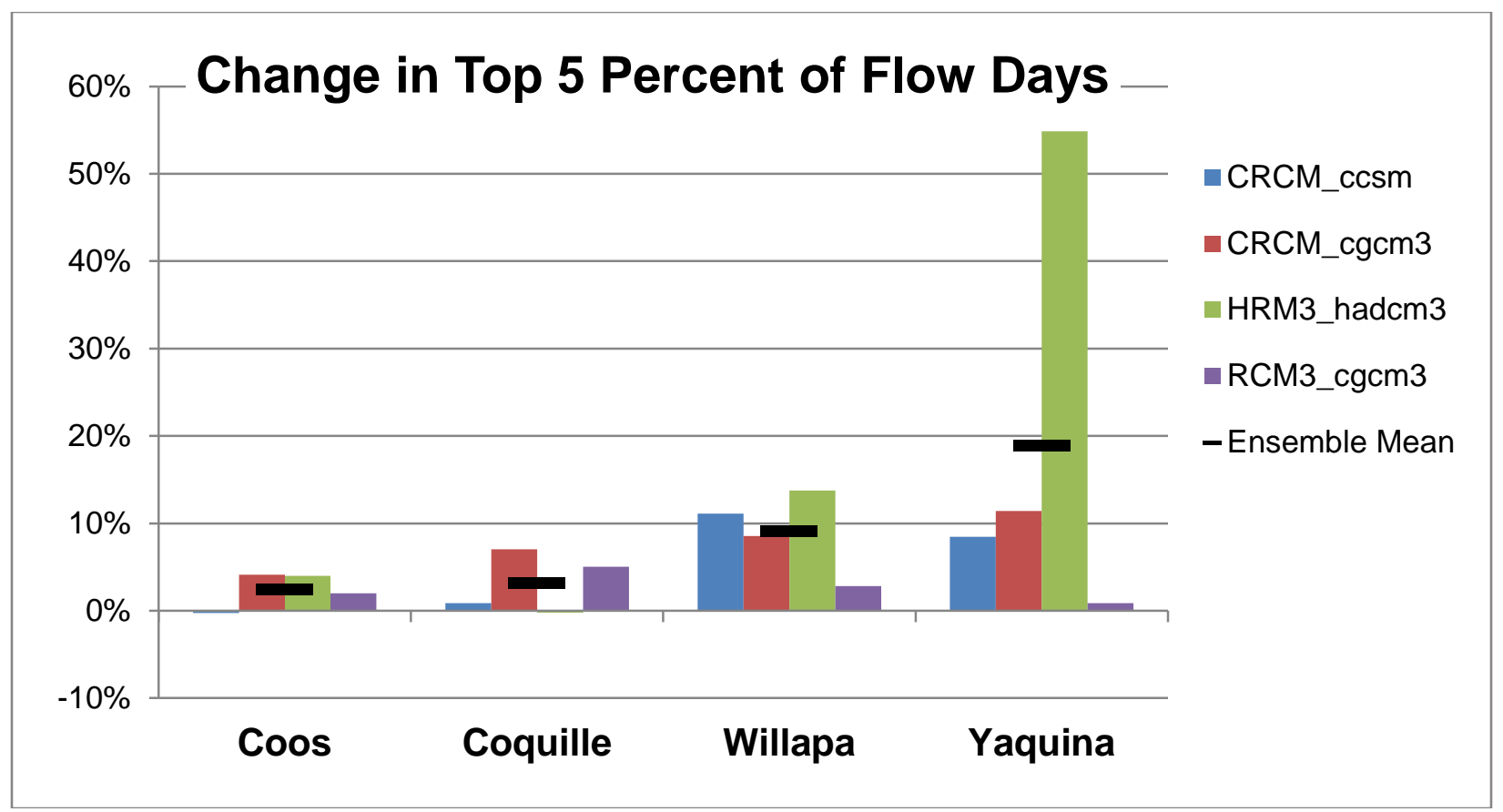

Figure 29. Graph showing percent change in flow in top 5 percent of days from reference period (19711995) to future period (2041-2065).

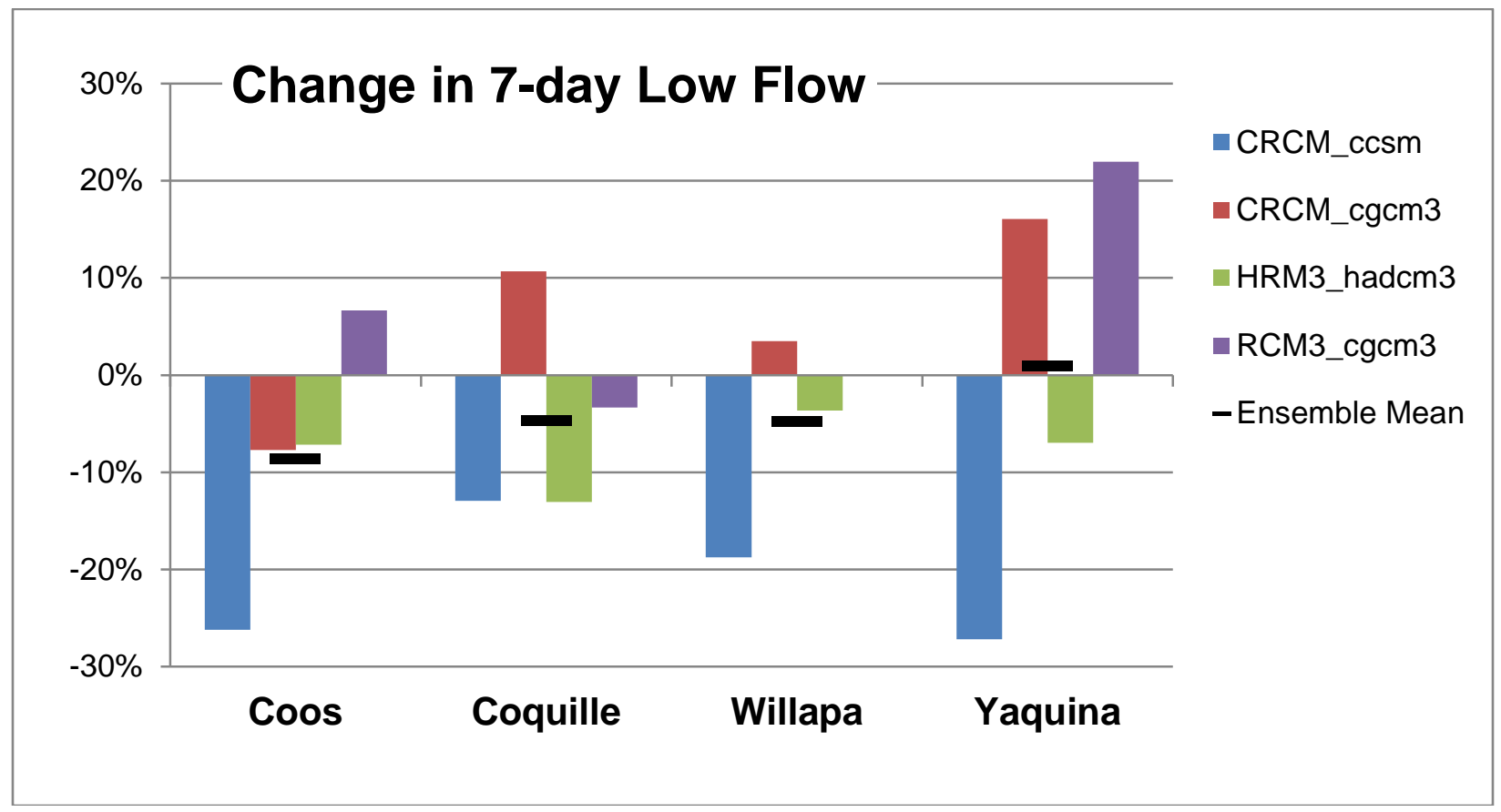

Figure 30. Graph showing percent change in 7-day low flow from reference period (1971-1995) to future period (2041-2065). 


\section{Uncertainty Analysis Results}

\section{PRMS Parameter Uncertainty}

Figures 31, 32, 33, and 34 show the uncertainty owing to model parameters in the four calibration sub-watersheds. In each figure, the red points represent observed flow values, and the gray region shows the range of values generated by the randomly generated parameter sets that met performance criteria described in "Methods". For each model, results are displayed on a linear scale (a in figures) and logarithmic scale (b in figures), so that high- and low-flow uncertainty can be readily seen. In each model, the same 6-year period (October 1984September 1990) is shown, and the X- axis represents number of days. The logarithmic charts show that the uncertainty of low flow is high, which agrees well with previous research (for example, Chang and Jung, 2010). The smallest calibration sub-watershed, for the Coos Bay South Slough, shows consistent under-prediction of the high flow, regardless of the parameter set used. The range of possible values does not include the observed data point in several cases. This may suggest a systematic bias in PRMS that becomes more obvious in smaller watersheds, and it also may be related to a possible underestimation of precipitation data.

\section{NARCCAP Uncertainty}

To assess uncertainty associated with climatic data, we used the random parameter sets that performed well in the calibration sub-watershed to create multiple models of the ungaged watersheds, which we then forced with the NARCCAP climate scenario data. Statistics from the resulting outputs are shown in figures 35 and 36 . In figure 35, the percent change in each statistic (top 5 percent of flow, 7-day low flow, and CV), from the reference period to the future period, is shown for each watershed and each climate scenario. The lines in the middle of the boxes denote the median values and the upper and lower boundaries of the boxes show the 25th and 75th percentiles, respectively. The red diamond symbol indicates outliers. There are considerable differences among the scenarios for each statistic and each watershed. Percent change in CV for the Yaquina Bay watershed is an extreme example of such discrepancies; the ranges of values for each scenario do not overlap.

Figure 36 shows the percent change in flow for each month, by watershed, with a separate box plot for each scenario. As in figure 35, the lines in the middle of the boxes denote the median values, the upper and lower boundaries of the boxes show the 25th and 75th percentiles, and red diamonds represent outliers. In many cases, there is little overlap in the range of changes among the four scenarios; this is especially evident in March and April, when RCM3CGCM and CRCM-CGCM3 show increases, and HRM3-HADCM3 and CRCM-CCSM show decreases. The HRM3-HADCM3 model, which shows the greatest increases in autumn flow, also has the greatest range of results.

These boxplots, with their lack of agreement among models, confirm that the selection of climate models, rather than hydrologic parameter values, is the greatest source of uncertainty. Many previous studies have reached the same conclusion (for example, Wilby and Harris, 2006; Graham and others, 2007; Maurer, 2007; Prudhomme and Davies, 2009; and Chang and Jung, 2010). 

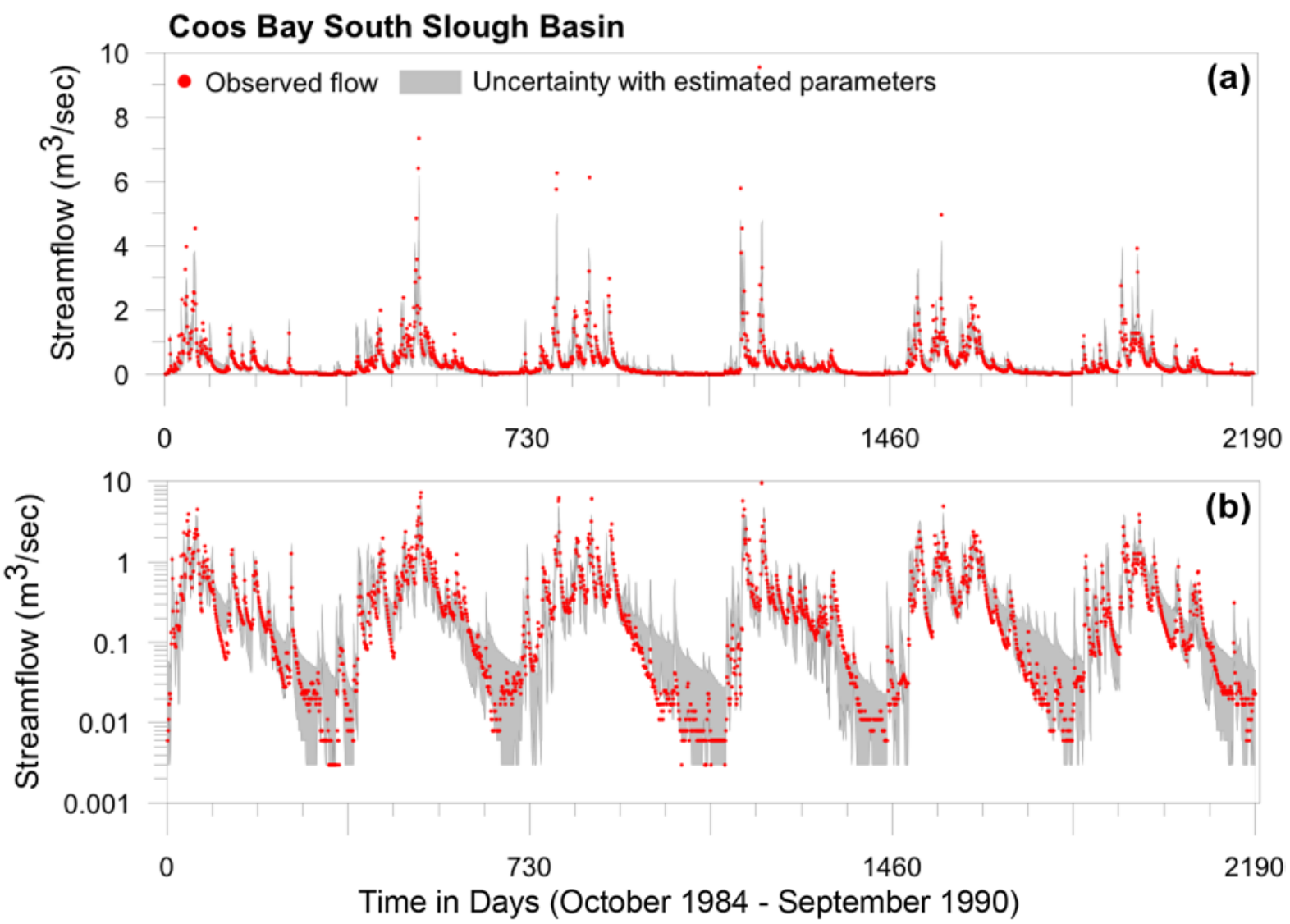

Figure 31. Precipitation Runoff Modeling System parameter uncertainty for Coos Bay calibration subwatershed, Oregon. (a) is a linear scale, and (b) is a logarithmic scale. 

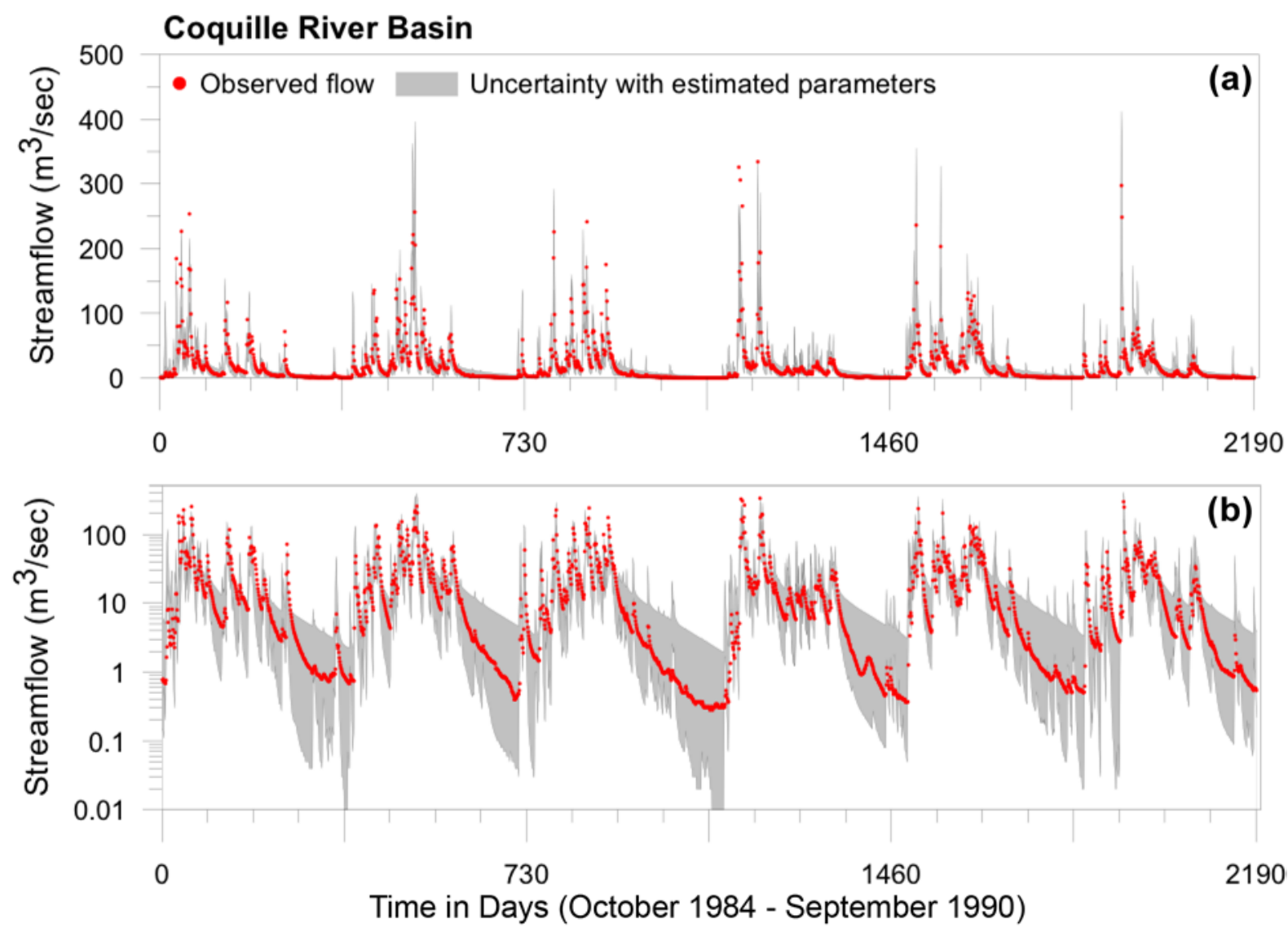

Figure 32. Precipitation Runoff Modeling System parameter uncertainty for Coquille River calibration subwatershed, Oregon. (a) is a linear scale, and (b) is a logarithmic scale. 

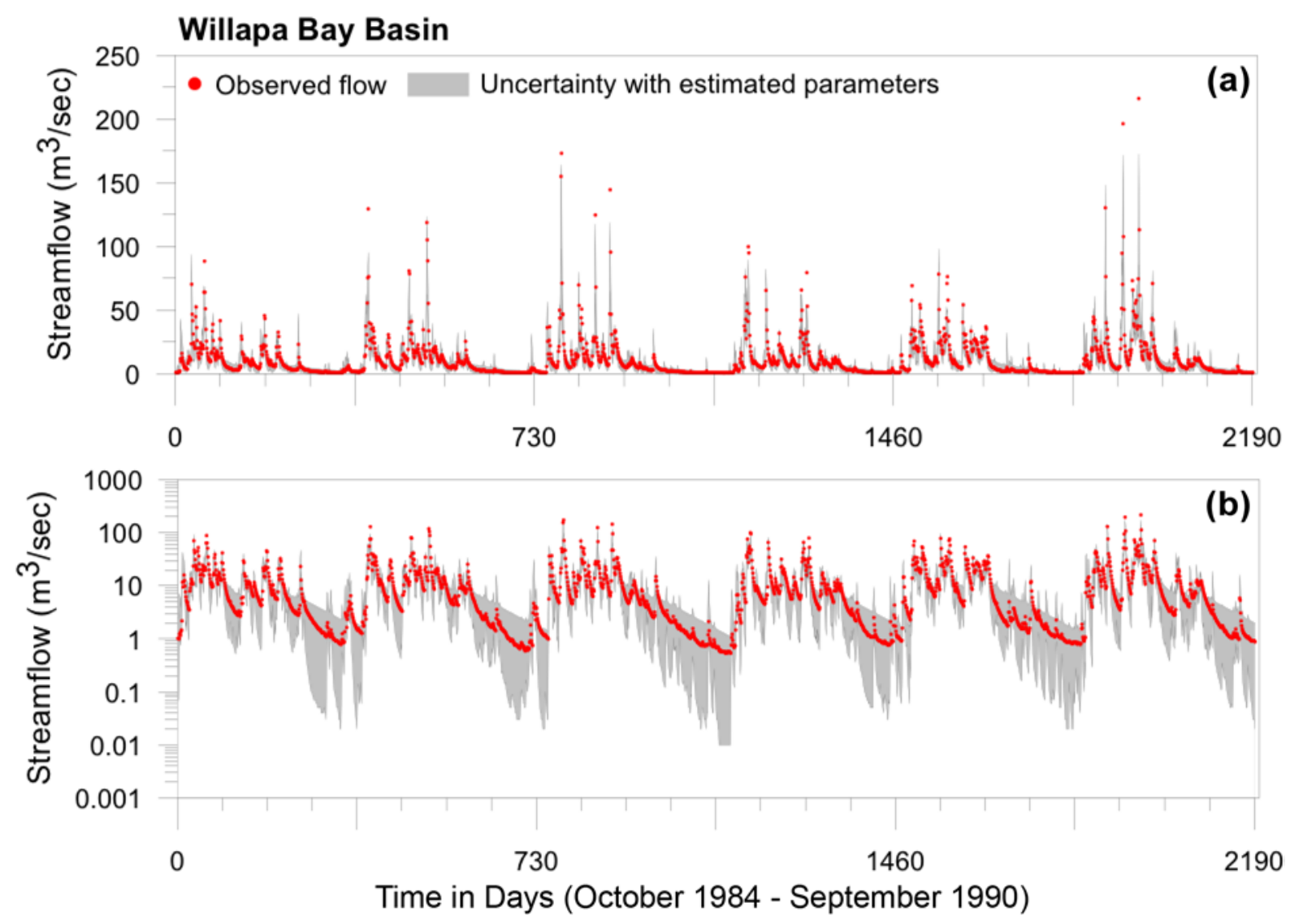

Figure 33. Precipitation Runoff Modeling System parameter uncertainty for Willapa Bay calibration subwatershed, Washington. (a) is a linear scale, and (b) is a logarithmic scale. 

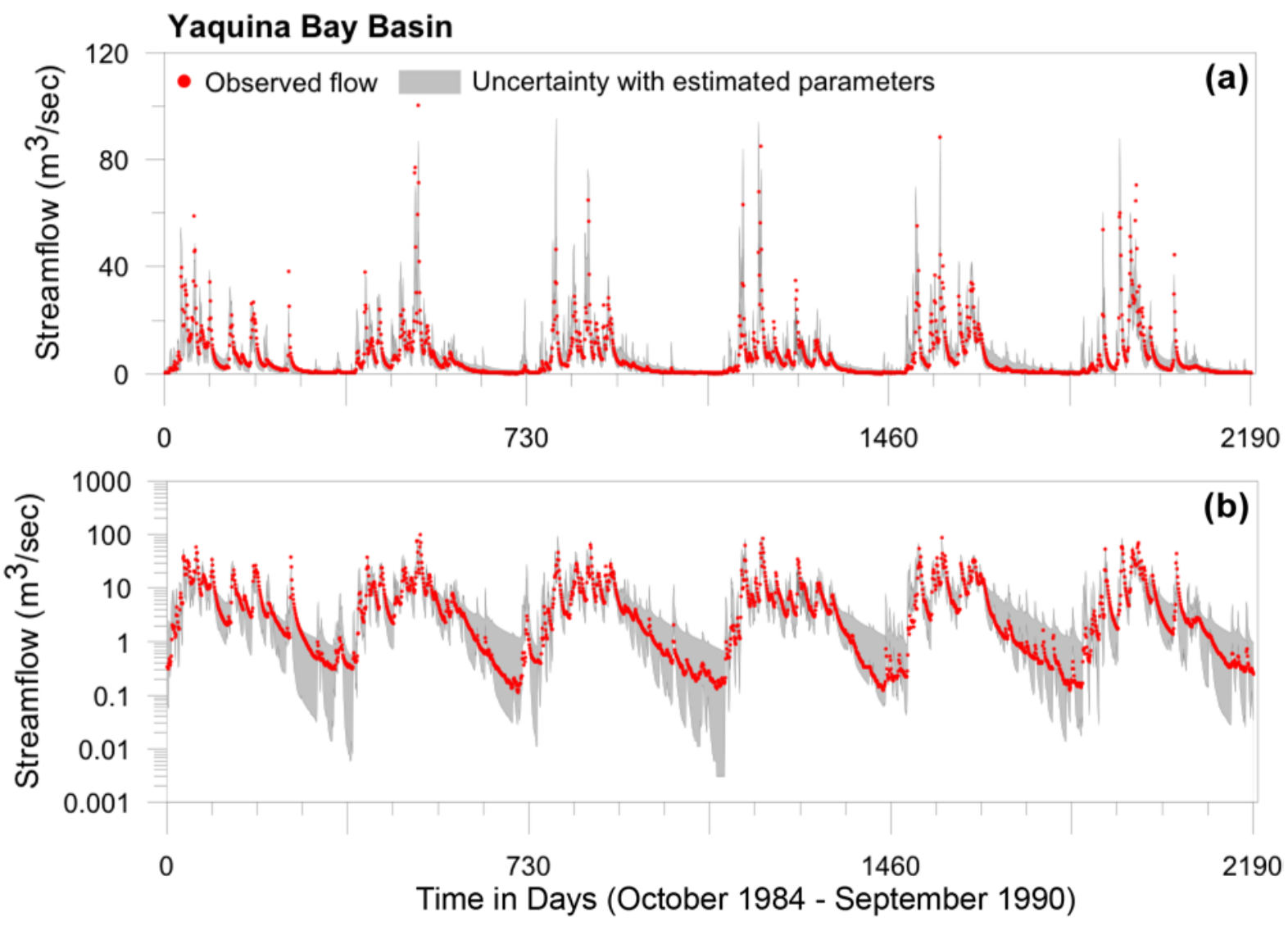

Figure 34. Precipitation Runoff Modeling System parameter uncertainty for Yaquina Bay calibration subwatershed, Oregon. (a) is a linear scale, and (b) is a logarithmic scale. 

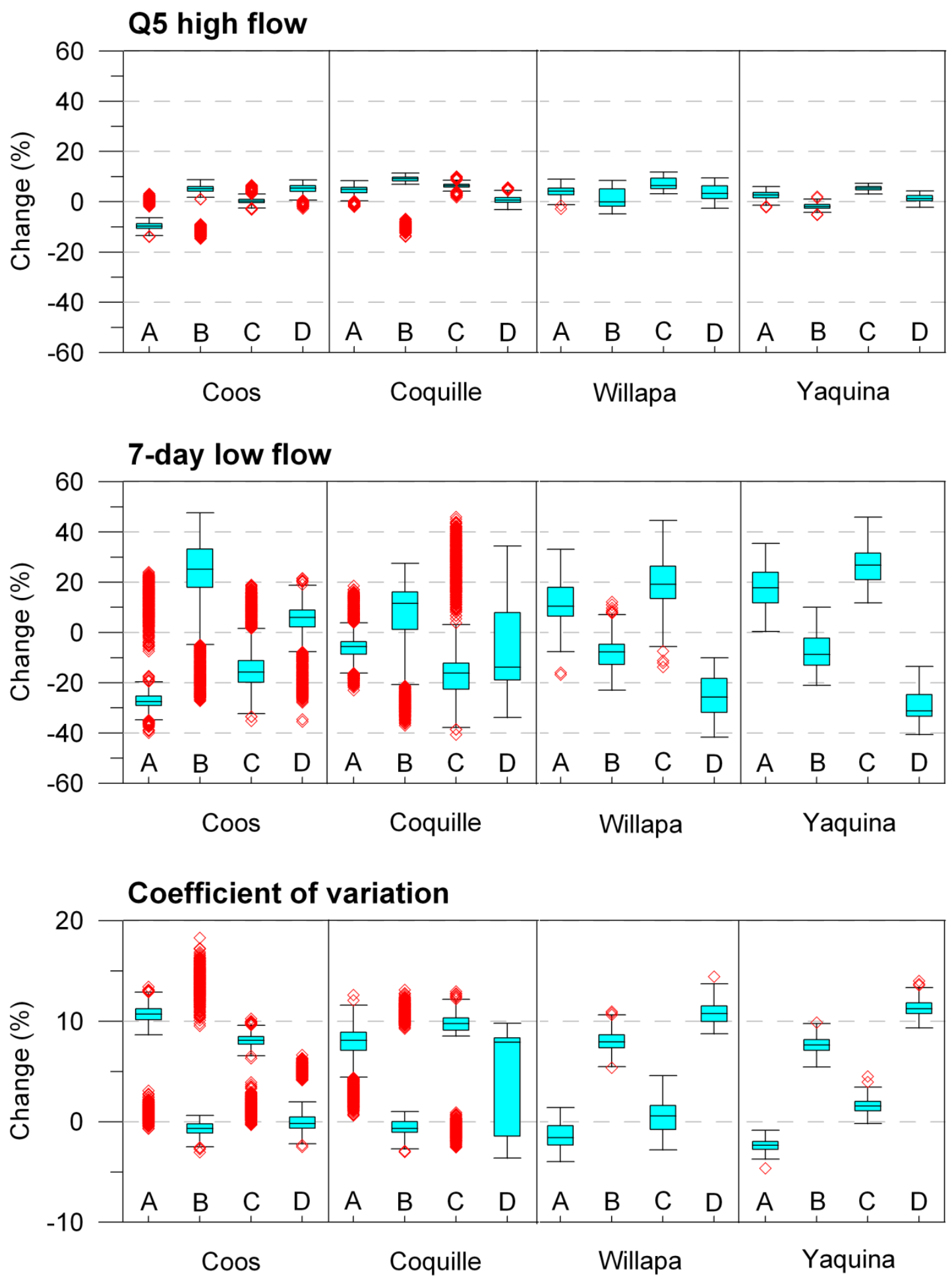

Figure 35. Box-and-whisker plots showing changes in top 5 percent high flow, 7-day low flow, and coefficient of variation for four study areas. The lines in the middle of boxes denote the median values, and the upper and lower boundaries of the boxes show the 25th and 75th percentiles, respectively. The red diamond symbol indicates outliers. A is for RCM3-CGCM, $\mathrm{B}$ is for HRM3-HADCM3, $\mathrm{C}$ is for CRCMCGCM3, and $\mathrm{D}$ is for CRCM-CCSM. 

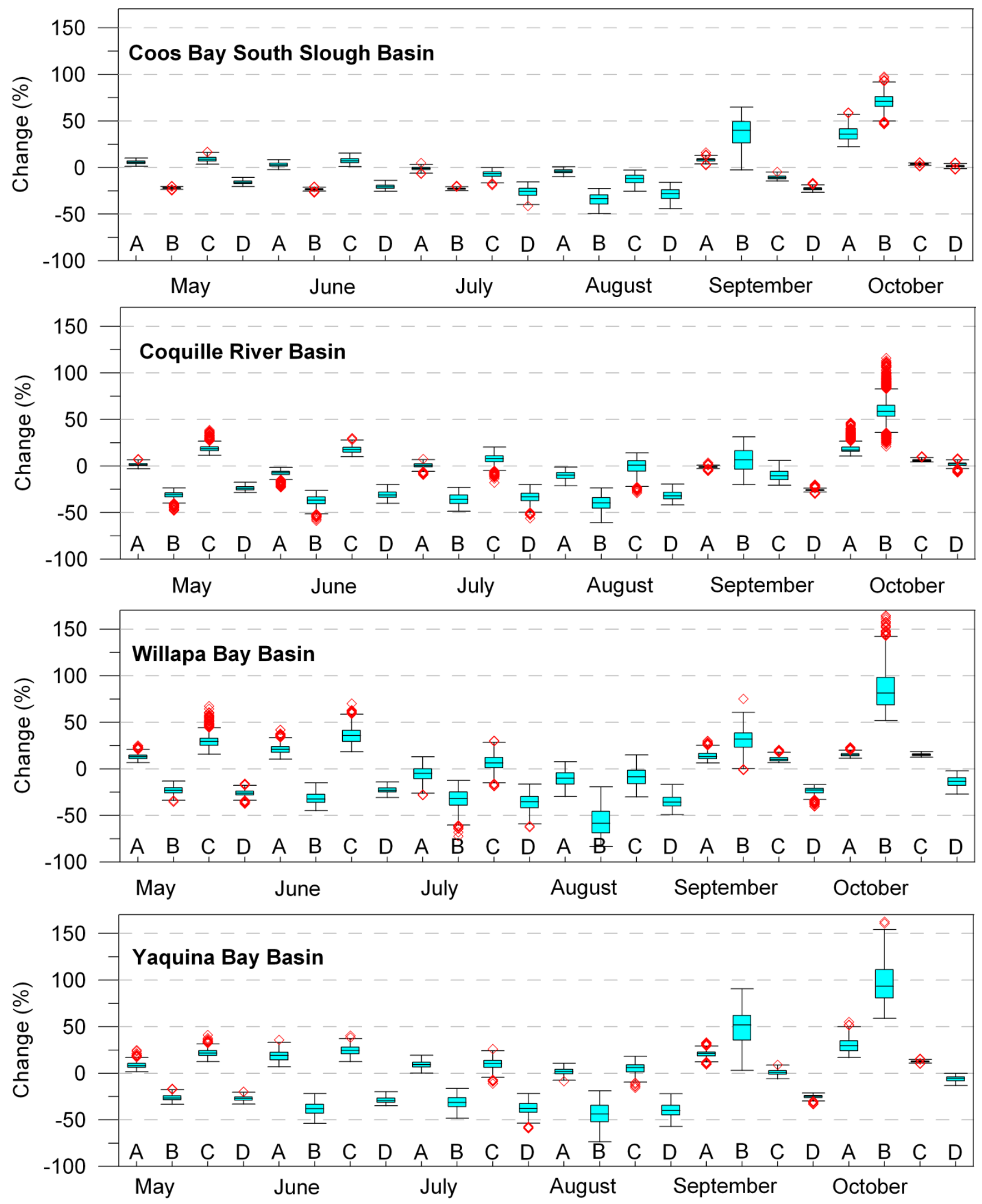

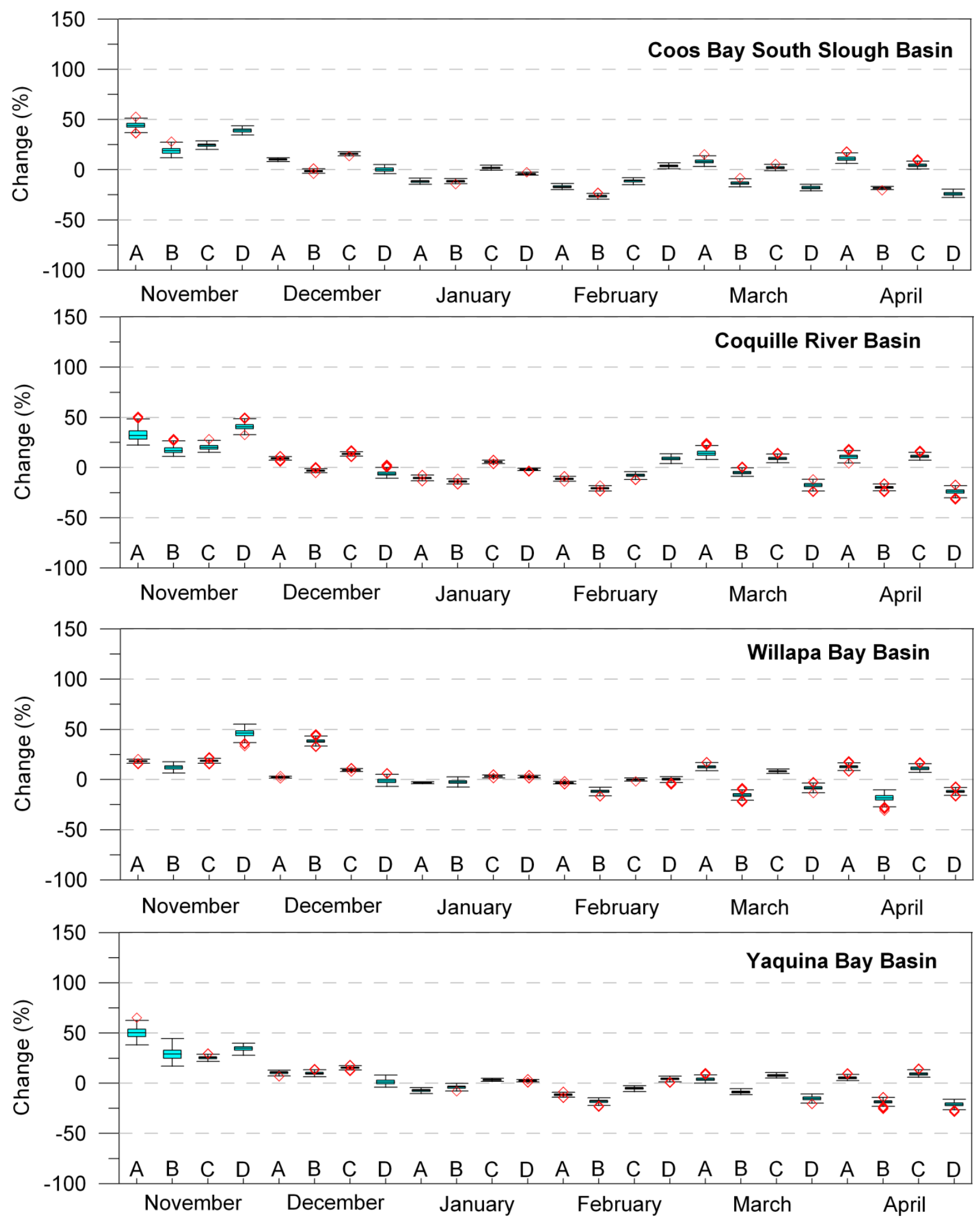

Figure 36. Box-and-whisker plots showing changes in monthly runoff for four study areas. The lines in the middle of boxes denote the median values, and the upper and lower boundaries of the boxes show the 25th and 75th percentiles, respectively. The red diamond symbol indicates outliers. A is for RCM3CGCM, $B$ is for HRM3-HADCM3, $C$ is for CRCM-CGCM3, and D is for CRCM-CCSM. 


\section{Discussion}

\section{Study Limitations}

This study has several important limitations. First, only four climate scenarios were used, and only one greenhouse gas emission scenario was used. Thus, the full range of possible climate change effects on watershed hydrology is greater than that reported here. Second, constant land cover parameters were used in model calibration and in future simulations, although some changes in land cover type occurred during the base period, and more will likely occur in the future. Modeling the effects of logging, which is common in these coastal areas, on hydrology would be an excellent extension of this study. Third, a full sensitivity analysis, which could calculate the influence of the various parameters over time and space, was beyond the scope of this study. Fourth, PRMS does not consider sub-daily flow variability, which can be considerable in these steep, narrow watersheds, nor can it model geomorphology and in-stream processes. Fifth, the groundwater component of PRMS is quite simple compared to other hydrologic models such as Ground water and Surface-water FLOW (GSFLOW). It would have been difficult, though, to calibrate a more complex groundwater model in the study watersheds as groundwater head data points are extremely scarce in the coastal PNW (Marshall Gannet, U.S. Geological Survey, personal commun.). Sixth, PRMS does not consider wind as a climate input, although it can strongly affect evapotranspiration. Finally, climatic data were averaged across the watersheds, which obscures local variation due to coastal effects, orographic effects, and topographic complexity.

\section{Key Findings}

Despite the limitations of this study, the research has yielded several findings. First, the random parameter set generated in the uncertainty analysis for these watersheds systematically underestimated high flows. This finding could be attributed to limitations in the modeling of extreme flows by PRMS (fig. 31), which suggests that further research into PRMS's ability to simulate accurately extreme flow events would be helpful. The high flow underestimation bias also may be due to underestimation of precipitation in the CIG data in the study watersheds.

Second, by comparing future outputs to reference outputs for each scenario, in each watershed, we determined that increases in autumn flow are probable in most watersheds. This change is driven directly by increases in precipitation in the same period in the NARCCAP climate data. Third, increases in the top 5 percent of flow days are likely, as are increases in late summer variability in flow and decreases in summer flow. Fourth, our uncertainty analysis demonstrated that there is more uncertainty associated with low flows. Therefore, findings regarding summer flows should be interpreted with caution. Finally, the uncertainty analysis also confirmed that the primary source of uncertainty in future flow projections is the climate models, rather than PRMS parameter values. Given that all NARCCAP climate simulations are based on a single emission scenario that does not represent the full range of possible emission levels, the uncertainty due to climate change is even greater than is indicated by these findings.

\section{Conclusions}

We modeled four coastal watersheds that drain to important estuaries in the Pacific Northwest as part of a larger interagency investigation into the possible effects of anthropogenic climate change on estuaries and ecosystem services they provide. Our findings show that change 
in the freshwater inflow regimes of these watersheds is likely. In particular, increases in autumn flow and increases in the top 5 percent of flow are probable. As in previous studies, the results also show that most of the considerable uncertainty in these projections is owing to the climate models used. Not only were there large discrepancies in the degree of the changes of many indices, but there also were differences in direction as well. In these rainwater dominated coastal watersheds, the primary driver of flow changes will be shifts in precipitation, which are difficult to simulate accurately. Nevertheless, our outputs allow coastal managers to see a range of possible changes, which may help them prepare for climate change. Our simulated flow output also can be used as input to models of estuarine ecosystems and water dynamics that can be used to better understand possible climate-driven shifts in the location, quality, and extent of critical estuarine habitat.

Although this study modeled only freshwater flow changes, these flow changes will likely lead to shifts in numerous other important estuarine variables, especially salinity. Altered salinity could affect the distribution and abundance of native species, and encourage the spread of invasive species. Freshwater flow declines in summer also could lead to reduced levels of dissolved oxygen, which will have negative implications for salmonids and could lead to hypoxia. Bacterial impairments also may increase, because drier summers may be followed by more extreme heavy rains in autumn. In the past, such weather patterns have contributed to high concentrations of fecal coliform levels in the Tillamook Bay. Therefore, the potential changes in freshwater flow highlighted by this study have many implications for water-quality conditions and distribution of aquatic organisms in Pacific Northwest estuaries, but further research is needed to determine the degree and likelihood of these possible shifts.

\section{Acknowledgments}

Thanks very much to Dr. Phil Mote, Oregon Climate Change Research Institute (OCCRI) Director, and Darrin Sharp, OCCRI Faculty Research Assistant, for extracting and resampling the NARCCAP data used in this research. We are also grateful to Marshall Gannett and John Risley of the USGS for their advice and feedback during initial planning, and to reviewers at the U.S. Environmental Protection Agency (EPA) and the USGS, whose comments greatly strengthened the report. This publication was subjected to review by the National Health and Environmental Effects Research Laboratory's Western Ecology Division of the EPA (EPA Report Number EPA/600/R/12/634), and the USGS Western Fisheries Research Center, and is approved for publication. However, approval does not signify that the contents reflect the views of the EPA.

\section{References Cited}

Ame, John, 2007, Yaquina watershed, North Coast Explorer: Oregon State University Libraries web site, accessed November 9, 2012, at http://oregonexplorer.info/northcoast/NorthCoastWatersheds/YaquinaWatershed.

Bae, D.H., Jung, I.-W., and Chang, Heejun, 2007, Potential changes in Korean water resources estimated by high resolution climate simulation: Climate Research, v. 35, no. 3, p. 213-226.

Bauer, John, Lev, Esther, Miller, Aileen, and Christy, J.A., 2011, Yaquina Estuary Conservation Plan: Tualatin, Oregon, The Wetlands Conservancy, accessed November 9, 2012, at http://www.wetlandsconservancy.org/ConservationPlans/yaquinaestuary/Yaquina\%20Estuary \%20Conservation\%20Plan\%20June\%202011.pdf 
Beven, Keith, and Freer, Jim, 2001, Equifinality, data assimilation, and uncertainty estimation in mechanistic modelling of complex environmental systems using the GLUE methodology: Journal of Hydrology, v. 249, p. 11-29.

Beven, Keith, Smith, Paul, and Freer, Jim, 2007, Comment on “Hydrological forecasting uncertainty assessment-Incoherence of the GLUE methodology” by Pietro Mantovan and Ezio Todini: Journal of Hydrology, v. 338, p. 315-318.

Brown, C.A., and Power, J.H., 2011, Historic and recent patterns of dissolved oxygen in the Yaquina Estuary (Oregon, USA) - Importance of anthropogenic activities and oceanic conditions: Estuarine, Coastal, and Shelf Science, v. 92, p. 446-455.

Burlando, Paolo, and Rosso, Renzo, 2002, Effects of transient climate change on basin hydrology - 2. Impacts on runoff variability in the Arno River, central Italy: Hydrological Processes, v. 16, no. 6, p. 1177-1199.

Chan, F., Barth, J.A., Lubchenco, J., Kirincich, A., Weeks, A., Peterson, W.T., and Menge, B.A., 2008, Emergence of anoxia in the California Current large marine ecosystem: Science, v. 319, no. 5865, p. 920.

Chang, Heejun, and Jung, I.-W., 2010, Spatial and temporal changes in runoff caused by climate change in a complex large river basin in Oregon: Journal of Hydrology, v. 388, p. 186-207.

Choi, H.T., and Beven, K., 2007, Multi-period and multi-criteria model conditioning to reduce prediction uncertainty in an application of TOPMODEL within the GLUE framework: Journal of Hydrology, v. 332, p. 316-336.

Coquille Watershed Association, 2011, Introduction to the Coquille Watershed web site, accessed November 9, 2012, at http://www.coquillewatershed.org/Coquille_Facts.html.

Daly, C., Gibson, W.P., Taylor, G.H., Johnson, G.L., and Pasteris, P., 2002, A knowledge-based approach to the statistical mapping of climate: Climate Research v. 22, p. 99-113.

Davey, K.R., 2008, Latin hypercube sampling and pattern search in magnetic field optimization problems: Institute of Electrical and Electronics Engineers (IEEE) Transactions on Magnetics, v. 44, no. 6, p. 974-977.

Elsner, M.M., Cuo, L., Voisin, N., Deems, J.S., Hamlet, A.F., Vano, J.A., Mickelson, K.E.B., Lee, S.-Y. and Lettenmaier, D.P., 2010, Implications of the 21st century climate change for the hydrology of Washington State: Climate Change, v. 102, p. 225-260.

Falk, John, and Robison, George, 2010, Oregon Dams (shapefile): Oregon Department of Water Resources, accessed November 9, 2012, at http://navigator.state.or.us/sdl/data/shapefile/k24/oregon_dams_shp.zip.

Farnsworth, R.K., Thompson, E.S., and Peck, E.L., 1982, Evaporation atlas for the contiguous 48 United States: National Oceanic and Atmospheric Administration Technical Report NWS 33, accessed November 9, 2012, at http://www.weather.gov/oh/hdsc/PMP_related_studies/TR33.pdf.

Gibson, J.R., and Najjar, R.G., 2000, The response of Chesapeake Bay salinity to climateinduced changes in streamflow: Limnology and Oceanography, v. 45, no. 8, p. 1764-1772.

Graham, L.P., Hagemann, Stefan, Jaun, Simon, and Beniston, Martin, 2007, On interpreting hydrological change from regional climate models: Climatic Change, v. 81, p. 97-122.

Grantham, B.A., Chan, F., Nielsen, K.J., Fox, D.S., Barth, J.A., Huyer, A., Lubchenco, J., and Menge, B.A., 2004, Upwelling-driven nearshore hypoxia signals ecosystem and oceanographic changes in the northeast Pacific: Nature Geoscience, v. 429, p. 749-754.

Hamlet, A.F., Carrasco, Pablo, Deems, J., Elsner, M.M., Kamstra, Tyler, Lee, Carrie, Lee, S.-Y., Mauger, G.S., Salathé, E.P., Tohver, Ingrid, and Binder, L.W., 2010, Final report for the 
Columbia Basin climate change scenarios project: Seattle, University of Washington, Climate Impacts Group, accessed November 9, 2012, at

http://www.hydro.washington.edu/2860/report/.

Harr, R.D., 1982, Fog drip in the Bull Run municipal watershed, Oregon: Water Resources Bulletin, v. 18, p. 785-789.

Hay, L.E., McCabe, G.J., Clark, M.P., and Risley, J.C., 2009, Reducing streamflow forecast uncertainty-Application and qualitative assessment of the Upper Klamath River Basin, Oregon: Journal of the American Water Resources Association, v. 45, no. 3, p. 580-596.

Hilton, T.W., Najjar, B.A., Zhong, L., and Li, M., 2008, Is there a signal of sea-level rise in Chesapeake Bay salinity?: Journal of Geophysical Research, v. 113, C09002, doi:10.1029/2007JC004247.

Jung, I.-W., and Chang, Heejun, 2011, Assessment of future runoff trends under multiple climate change scenarios in the Willamette River Basin, Oregon, USA: Hydrological Processes, v. 25, no. 2, p. 258-277.

Jung, I.-W., Chang, Heejun, and Moradkhani, H., 2011, Quantifying uncertainty in urban flooding analysis considering hydroclimatic projection and urban development effects: Hydrology and Earth System Sciences, v. 15, no. 2, p. 617-633.

Kay, A.L., Jones, D.A., Crooks, S.M., Calver, A., and Reynard, N.S., 2006, A comparison of three approaches to spatial generalization of rainfall-runoff models: Hydrological Processes, v. 20, p. 3953-3973.

Kirchner, J.W., 2006, Getting the right answers for the right reasons-Linking measurements, analyses, and models to advance the science of hydrology: Water Resources Research, v. 42, W03S04, 5 p.

Lamorey, Gregg, 2009, PRMS HRU parameters: U.S. Geological Survey web site, accessed November 9, 2012, at http://wwwbrr.cr.usgs.gov/projects/SW_MoWS/4.1\%20HRU\%20Map.html.

Leavesley, G.H., Lichty, R.W., Troutman, B.M., and Saindon, L.G., 1983, Precipitation-Runoff Modeling System-User's manual: U.S. Geological Survey Water-Resources Investigation Report 83-4238, 207 p. (Also available at http://pubs.er.usgs.gov/publication/wri834238.)

Leavesley, G.H., and Stannard, L.G., 1995, The precipitation-runoff modeling system-PRMS, chap. 9 of Singh, V.P., ed., Computer models of watershed hydrology: Highlands Ranch, Colorado, Water Resources Publication, p. 281-310.

Lee II, H., and Brown, C.A., eds., 2009. Classification of regional patterns of environmental drivers and benthic habitats in Pacific Northwest estuaries: U.S. Environmental Protection Agency, Office of Research and Development, National Health and Environmental Effects Research Laboratory, Western Ecology Division. EPA/600/R-09/140.

Legates, D.R., and DeLiberty, T.L., 1993, Precipitation measurement biases in the United States: Water Resources Bulletin, v. 29, no. 5, p. 855-861.

Legesse, Dagnachew, Vallet-Coulomb, Christine, and Gasse, Françoise, 2003, Hydrological response of a catchment to climate and land use changes in tropical Africa-Case study South Central Ethiopia: Journal of Hydrology, v. 275, p. 67-85.

Levinton, J., Doall, M., Ralston, D., Starke, A., and Allam, B., 2011, Climate change, precipitation and impacts on an estuarine refuge from disease: PLoS ONE, v. 6, no. 4, e18849, doi:10.1371/journal.pone.0018849. 
Ma, L., Madin, I.P., Olson, K.V., and Watzig, R.J., 2009, Oregon Geologic Data Compilation (shapefile): Oregon Department of Geology and Mineral Industries (DOGAMI), accessed November 9, 2012, at http://navigator.state.or.us/sdl/data/OGDCv5.zip.

Markstrom, S.L., Niswonger, R.G., Regan, R.S., Prudic, D.E., and Barlow, P.M., 2008, GSFLOW - Coupled ground-water and surface-water flow model based on the integration of the Precipitation-Runoff Modeling System (PRMS) and the Modular Ground-Water Flow Model (MODFLOW-2005): U.S. Geological Survey Techniques and Methods 6-D1, 240 p., accessed November 9, 2012, at http://pubs.usgs.gov/tm/tm6d1/.

Maurer, E.P., 2007, Uncertainty in hydrologic impacts of climate change in the Sierra Nevada, California, under two emissions scenarios: Climatic Change v. 82, p. 309-325.

Merz, Ralf, and Bloschl, Günter, 2004, Regionalization of catchment model parameters: Journal of Hydrology, v. 287, p. 95-123.

Nakicenvoic, Nebojsa, Davidson, Ogunlade, Davis, Gerald, Grübler, Arnulf, Kram, Tom, La Rovere, E.L., Metz, Bert, Morita, Tsuneyuki, Pepper, William, Pitcher, Hugh, Sankovski, Alexei, Shukla, Priyadarshi, Swart, Robert, Watson, Robert, and Dadi, Zhou, 2000, Special report on emissions scenarios-A special report of Working Group III of the Intergovernmental Panel on Climate Change: Cambridge, United Kingdom, Cambridge University Press, 599 p.

Nash, J.E., and Sutcliffe, J.V., 1970, River flow forecasting through conceptual models part I-A discussion of principles: Journal of Hydrology, v. 10, no. 3, p. 282-290.

National Atlas of the United States, 2006, Major dams of the United States (shapefile): National Atlas of the United States web site, accessed November 9, 2012, at http://nationalatlas.gov/mld/dams00x.html.

National Climate Change and Wildlife Science Center at http://nccwsc.usgs.gov.

North American Regional Climate Change Assessment Program, 2011a, About NARCCAP: North American Regional Climate Change Assessment Program web site, accessed November 9, 2012, at http://www.narccap.ucar.edu/about/index.html.

North American Regional Climate Change Assessment Program, 2011b, ResultsCRCM+CCSM-Seasonal climate change: North American Regional Climate Change Assessment Program web site, accessed February 2, 2011, at http://www.narccap.ucar.edu/results/index.html\#climate-change.

North American Regional Climate Change Assessment Program, 2011c, The A2 emissions scenario: North American Regional Climate Change Assessment Program web site, accessed November 9, 2012, at http://www.narccap.ucar.edu/about/emissions.html.

Oregon Department of Transportation, 2009, City limits (2009)_City limits and city annexations for the State of Oregon (shapefile): Oregon Department of Transportation, accessed November 9, 2012, at http://navigator.state.or.us/sdl/data/shapefile/k24/citylim_2009.zip.

Oregon Coastal Management Program, 2011a, About estuaries in Oregon: Oregon Coastal Atlas web site, accessed November 9, 2012, at http://www.coastalatlas.net/index.php/learn/places/6estuaries.

Oregon Coastal Management Program, 2011b, Coos Bay estuary: Oregon Coastal Atlas web site, accessed November 9, 2012, at http://www.coastalatlas.net/?option=com_jumi\&view $=$ application\&fileid=8\&e=14\&Itemid $=$ 124. 
Oregon Coastal Management Program, 2011c, Yaquina Bay estuary: Oregon Coastal Atlas web site, accessed November 9, 2012, at

http://www.coastalatlas.net/?option=com_jumi\&view $=$ application\&fileid=8\&e=10\&Itemid $=$ 124.

Oregon Department of Environmental Quality, 1995, Dissolved oxygen, 1992-1994 Water

Quality Standards Review: Oregon Department of Environmental Quality.

Praskievicz, Sarah, and Chang, Heejun, 2009, A review of hydrologic modeling of basin-scale climate change and urban development impacts: Progress in Physical Geography, v. 33, p. 650-671.

PRISM Climate Group, 2012, PRISM Climate Group web site: Corvallis, Oregon State University, PRISM Climate Group, accessed November 9, 2012, at http://prism.oregonstate.edu.

Prudhomme, Christel, and Davies, Helen, 2009, Assessing uncertainties in climate change impact analyses on the river flow regimes in the UK-Part 2-Future climate: Climatic Change, v. 93, p. 19-222.

Qi, S., Sun, G., Wang, Y., McNulty, S.G., and Myers, J.A.M., 2009, Streamflow response to climate and landuse changes in a coastal watershed in North Carolina: Transactions of the American Society of Agricultural and Biological Engineers, v. 52, p. 739-749.

Roegner, G.C., Needoba, J.A., and Baptista, A.M., 2011, Coastal upwelling supplies oxygendepleted water to the Columbia River estuary: PLoS ONE, v. 6, no. 4, e18672, doi:10.1371/journal.pone.0018672.

Roessing, J.M., Woodley, C.M., Cech Jr., J.J., and Hansen, L.J., 2004, Effects of global climate change on marine and estuarine fishes and fisheries: Reviews in Fish Biology and Fisheries, v. 14, p. 251-275.

Ruggiero, Peter, Brown, C.A., Komar, P.D., Allan, J.C., Reusser, D.A., and Lee, Henry, 2010, Impacts of climate change on Oregon's coasts and estuaries, chap. 6 of Dello, K.D. and Mote, P.W., eds., Oregon climate assessment report: Corvallis, Oregon State University, College of Oceanic and Atmospheric Sciences, p. 211-268.

Salathe Jr., E.P., Mote, P.W., and Wiley, M.W., 2007, Review of scenario selection and downscaling methods for the assessment of climate change impacts on hydrology in the United States Pacific Northwest: International Journal of Climatology, v. 27, p. 1611-1621.

Scavia, D., Field, J.C., Boesch, D.F., Buddemeier, R.W., Burkett, V., Cayan, D.R., Fogarty, M., Hartwell, M.A., Howarth, R.W., Mason, C., Reed, D.J., Royer, T.C., Sallenger, A.H., and Titus, J.G., 2002, Climate change impacts on U.S. coastal and marine ecosystems: Estuaries, v. 25, p. 149-164.

Sullivan, T.J., Snyder, K.U., Gilbet, E., Bischoff, J.M., Wusternberg, M., Moore, J., and Moore, D., 2005, Assessment of water quality in association with land use in the Tillamook Bay watershed, Oregon, USA: Water, Air, and Soil Pollution, v. 161, p. 3-23.

Stachowicz, J.J., Terwin, J.R., Whitlatch, R.B., and Osman, R.W., 2002, Linking climate change and biological invasions-Ocean warming facilitates nonindigenous species invasions: Proceedings of the National Academy of Sciences of the United States of America, v. 99, p. 15497-15500.

U.S. Census Bureau, 2011, American FactFinder: U.S. Census Bureau web site, accessed November 9, 2012, at http://factfinder2.census.gov/. 
U.S. Environmental Protection Agency, 2003, EPA Region 10 guidance for Pacific Northwest state and tribal temperature water quality standards: U.S. Environmental Protection Agency, Region 10, Office of Water, EPA-910-B-03-002.

U.S. Fish and Wildlife Service, 2011, Willapa National Wildlife Refuge: U.S. Fish and Wildlife Service web site, accessed November 9, 2012, at http://www.fws.gov/refuges/profiles/index.cfm?id=13552.

U.S. Geological Survey, 2011, Questions frequently asked by modelers of watershed systems: U.S. Geological Survey Central Region Researh web site, accessed April 5, 2011, at http://wwwbrr.cr.usgs.gov/projects/SW_MoWS/FAQ.html.

Wilby, R.L., 2005, Uncertainty in water resource model parameters used for climate change impact assessment: Hydrological Processes, v. 19, p. 3201-3219.

Wilby, R.L., and Harris, I., 2006, A framework for assessing uncertainties in climate change impacts-Low-flow scenarios for the River Thames, UK: Water Resources Research, v. 42, W02419. 20 p.

Winder, M., Jassby, A.D., and MacNully, R., 2011, Synergies between climate anomalies and hydrological modification facilitate estuarine biotic invasions: Ecology Letters, v. 14, no. 8, p. 749-757.

Wolf, E.C., 1993, A tidewater place-Portrait of the Willapa ecosystem: Portland, Oregon, Ecotrust web site, accessed November 9, 2012, at http://www.ecotrust.org/publications/tidewater_place.html.

Wood, A.W., Leung, L.R., Sridhar, V., and Lettenmaier, D.P., 2004, Hydrologic implications of dynamical and statistical approaches to downscaling climate model outputs: Climate Change, v. 62, p. 189-216. 


\section{Appendix A. Presentations and Posters Based on this Research}

Chang, H., Steele, M., and Jung, I-W., Basin responses to climate change in heterogeneous hydrologic landscape regions: Poster presented at the American Geophysical Union Meeting of the Americas, Iguassu Falls, Brazil, August 10, 2010.

Chang, H., Steele, M., Jung, I.-W., and Salathe, E., Potential impacts of climate change on runoff generation processes across different hydrologic landscape regions: Poster presented at Hydrology Conference 2010, San Diego, California, October 11-13, 2010.

Steele, M., Chang, H., and Jung, I.-W., Potential climate-induced runoff changes in two Oregon coastal watersheds: Paper presented at the annual meeting of Oregon Academy of Sciences, Portland, Oregon, February 26, 2011.

Steele, M., Chang, H., and Jung, I.-W., Potential climate-induced runoff changes in Pacific Northwest coastal watersheds: Paper presented at the annual meeting of the Association of American Geographers, Seattle, Washington, April 14, 2011.

Steele, M., Chang, H., and Jung, I.-W., Possible climate-induced runoff changes and associated uncertainty in five Pacific Northwest coastal watersheds: Paper presented at the fall meeting of the American Geophysical Union, San Francisco, California, December 6, 2011. 